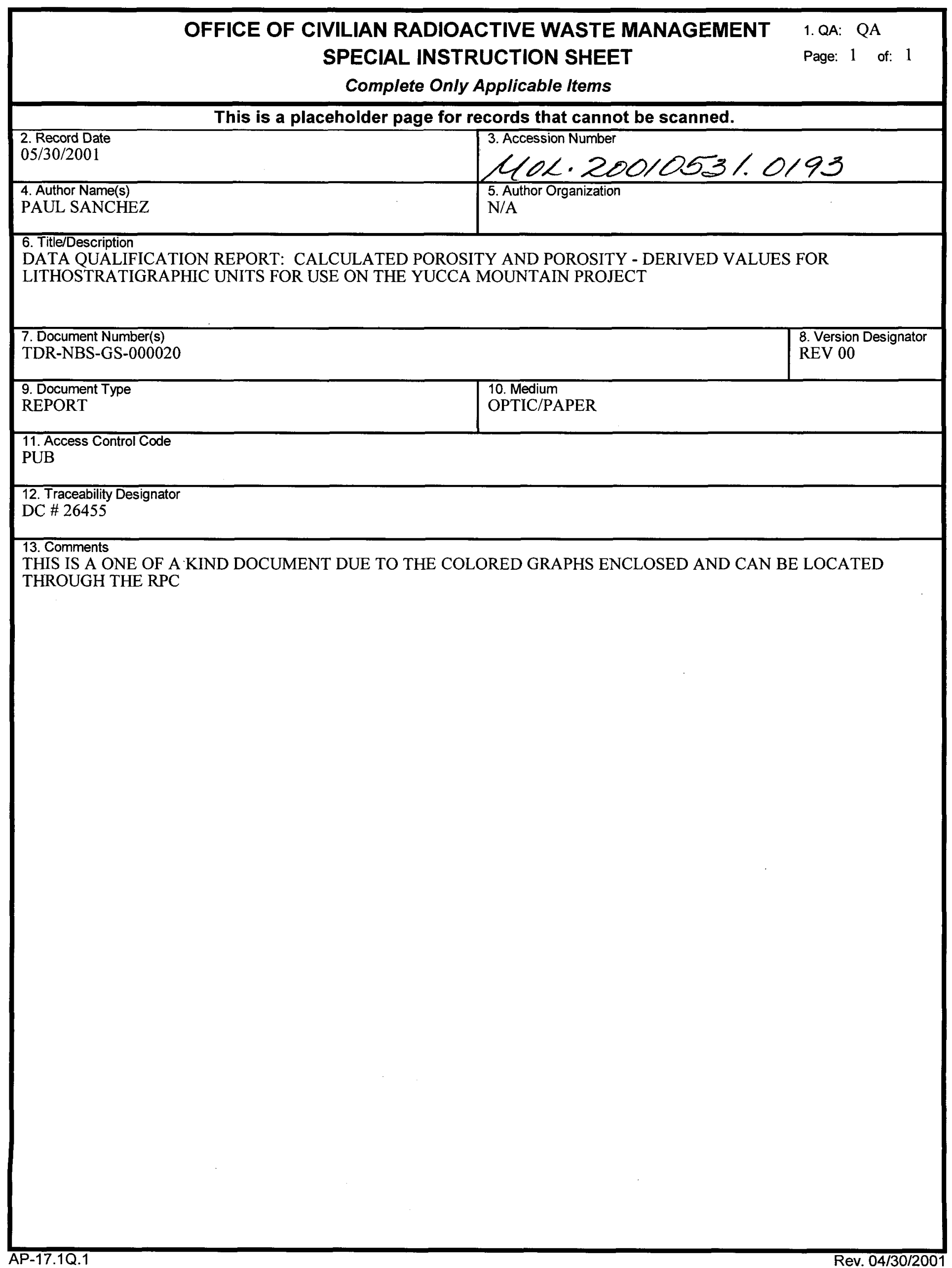


QA: QA

TDR-NBS-GS-000020 REV 00

May 2001

\title{
Data Qualification Report: Calculated Porosity and Porosity- Derived Values for Lithostratigraphic Units for Use on the Yucca Mountain Project
}

\author{
Prepared for: \\ U.S. Department of Energy \\ Yucca Mountain Site Characterization Office \\ P.O. Box 30307 \\ North Las Vegas, Nevada 89036-0307 \\ Prepared by: \\ Bechtel SAIC Company, LLC \\ 1180 Town Center Drive \\ Las Vegas, Nevada 89144 \\ Under Contract Number \\ DE-AC08-01NV12101
}




\section{DISCLAIMER}

This report was prepared as an account of work sponsored by an agency of the United States Government. Neither the United States Government nor any agency thereof, nor any of their employees, nor any of their contractors, subcontractors or their employees, makes any warranty, express or implied, or assumes any legal liability or responsibility for the accuracy, completeness, or any third party's use or the results of such use of any information, apparatus, product, or process disclosed, or represents that its use would not infringe privately owned rights. Reference herein to any specific commercial product, process, or service by trade name, trademark, manufacturer, or otherwise, does not necessarily constitute or imply its endorsement, recommendation, or favoring by the United States Government or any agency thereof or its contractors or subcontractors. The views and opinions of authors expressed herein do not necessarily state or reflect those of the United States Government or any agency thereof. 
Data Qualification Report: Calculated Porosity and Porosity-Derived Values for Lithostratigraphic Units for Use on the Yucca Mountain Project

Prepared by:

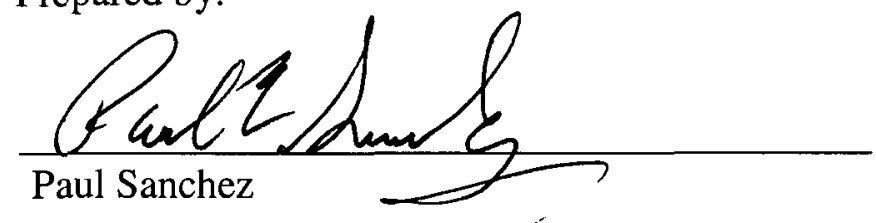

$$
\frac{5-30-01}{\text { Date }}
$$

Chairperson:

\section{leuth the.}

Clinton Lum

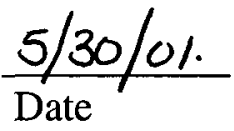

Date

Compliance Review by:

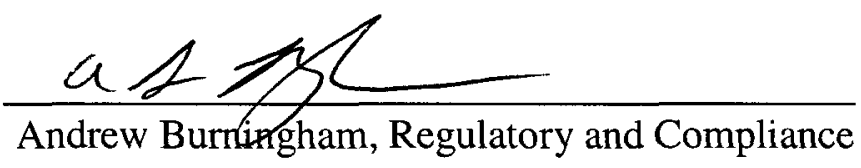

$$
\frac{5-30 / 01}{\text { Date }}
$$

Approved by:

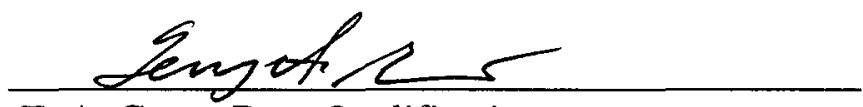

T. A. Grant, Data Qualification

P7quent

R. F. Wemheuer, Responsible Manager

$\frac{5 / 30 / 0 /}{\text { Date }}$
$\frac{05 / 30 / 0 /}{\text { Date }}$




\section{EXECUTIVE SUMMARY}

This qualification report is prepared in accordance with provisions of AP-SIII.2Q and Data Qualification Plan DQP-NBS-GS-000006, Rev. 00 (CRWMS M\&O 2001). The data being qualified are input and output data in the pre-Process Validation and Reengineering (PVAR) report, Combined Porosity from Geophysical Logs (CRWMS M\&O 1999a and hereafter referred to as Rael 1999), and further described below. Unqualified Data Tracking Number (DTN) MO9910POROCALC.000 contained the main output of the Rael (1999) analyses: calculated total porosity and effective porosity for 40 Yucca Mountain Project boreholes. Calculated porosities were compiled at specified depths in DTN MO9910POROCALC.000 and shown as borehole logs in Rael (1999).

Data reported in the original Rael (1999) output DTN MO9910POROCALC.000 have been grouped into the following new DTNs to address historical and modern boreholes separately:

- MO0010CPORGLOG.002. This DTN contains technical input data and calculated porosity results from historical boreholes drilled and tested prior to 1991. The DTN includes unqualified composite neutron porosity data selected by Rael (1999) as input to the porosity calculations. The neutron data were collected for the U.S. Geological Survey (USGS) before implementation of the approved USGS Quality Assurance Program Plan for the Yucca Mountain Project (YMP)

- MO0010CPORGLOG.003. This DTN contains technical input data and calculated porosity results from modern (post-1991) boreholes. The calculated results utilized qualified geophysical logs that were collected and developed in accordance with approved YMP procedures under the Quality Assurance Requirements and Description Document (QARD). All modern geophysical borehole log inputs have also undergone forensic analyses, a process that verifies the accuracy of the borehole logging data and are qualified. This DTN includes previously unsubmitted porosity results for USW SD-6 and USW WT-24.

In addition, DTN MO0105CPORGLOG.004 contains the USGS geophysical neutron data and composite neutron porosity logs used in the porosity calculations for historical boreholes.

The unqualified status of the output for the modern borehole data set is mainly due to the use of unqualified software. In addition, the calculations relied on unqualified data and the porosity results are based on pre-PVAR methodology. The unqualified status of the historical borehole output results from insufficiently documented methodology, unqualified software and similar data issues. For both historical and modern data sets, the previously unqualified software QLA V2.2 (Software Tracking Number: 10082-2.2-00) has subsequently been qualified and checked (CRWMS M\&O 2000c).

This data qualification activity emphasizes corroboration and technical assessment of the porosity results from Rael (1999) and the corresponding developed input for each borehole. The modern data set is included in the qualification analyses of the historical data set and is 
considered qualified, as discussed below. The recommendation to qualify the historical and modern data sets are based on the following rationale:

- Rael (1999) documents the previously undocumented methodology used by Nelson (1996) to derive porosity results for the historical boreholes and documents the similar methodology for the modern borehole data set. (DTNs MO0010CPORGLOG.002 and MO0010CPORGLOG.003)

- Historical unqualified neutron porosity geophysical input from Nelson (1996) used by Rael (1999) are found to be of adequate quality based on review of two preliminary forensic analyses. The two historical boreholes assessed are USW H-6 and UE-25 p\#1 (DTNs MO0010CPORGLOG.002 and MO0105CPORGLOG.004).

- The forensic analyses for the two historical boreholes document that the primary historical logging contractors employed industry standard practices and collected other quality geophysical data at the time, including the neutron data. This provides confidence in unqualified neutron porosity data for all historical boreholes (DTNs MO0010CPORGLOG.002 and MO0105CPORGLOG.004).

- Modern geophysical log-based porosity data is visually corroborated with core porosity data in modern boreholes USW SD-7, USW SD-12, USW SD-9, UE-25 UZ\#16 and USW NRG 7A; Figures 2 through 6, respectively (DTNs MO0010CPORGLOG.002 and MO001OCPORGLOG.003).

- Figure 7 exhibits a linear correlation between total porosities obtained from core samples and log-derived total porosities calculated using both the modern and historical sets (DTNs MO0010CPORGLOG.002 and MO0010CPORGLOG.003).

- While Figures 2 through 6 visually corroborate only modern borehole results, it is important to emphasize that porosity calculations for historical boreholes relied on the same equations, methods and input as applied to modern boreholes. Consequently, the corroboration of the modern boreholes and the linear correlation established in Figure 7 provides evidence of the quality of both the modern and historical borehole sets (DTNs MO0010CPORGLOG.002 and MO0010CPORGLOG.003).

- Where both modern and historical geophysical measurements existed in the same borehole, comparable porosity results were achieved using input from the modern data set and the corresponding historical data set (i.e., USW G-2, USW WT-10, USW WT-2, and UE-25 WT\#12). Rael (1999) showed similar results comparing neutron porosity data from the old and modern data sets (DTN MO0010CPORGLOG.002).

- Subsurface distributions of porosity data for modern and historical boreholes are assessed and corroborated with adjacent boreholes along lines of section based on the inferred geologic continuity of stratigraphic and porosity sequences from borehole to borehole (DTNs MO0010CPORGLOG.002 and MO0010CPORGLOG.003). 
- Reproducibility of the Nelson (1996) methodology and validation of the output through technical assessment discussed above validate the methodology employed by Rael (1999), including the porosity output and associated developed input (DTNs MO0010CPORGLOG.002, MO0010CPORGLOG.003 and MO0105CPORGLOG.004).

Based on the preponderance of evidence summarized above, the Data Qualification Team considers the data in DTNs MO0010CPORGLOG.002, MO0010CPORGLOG.003 and MO0105CPORGLOG.004 qualified for general use on the YMP. The original DTN MO9910POROCALC.000 should remain unqualified since it is superseded by DTNs MO0010CPORGLOG.002 and MO001OCPORLOG.003. 


\section{CONTENTS}

EXECUTIVE SUMMARY iv

ACRONYMS AND ABBREVIATIONS …………............................................................

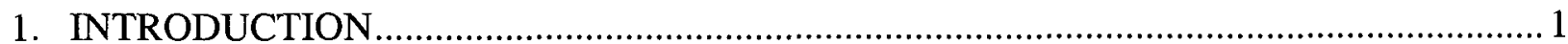

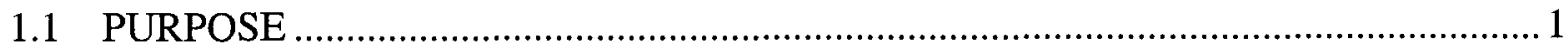

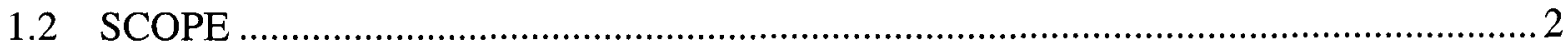

1.3 BACKGROUND

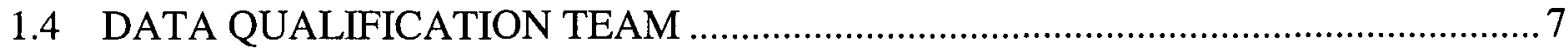

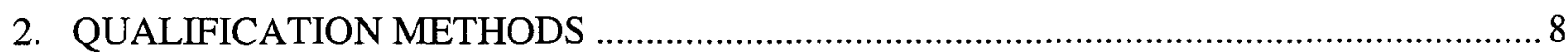

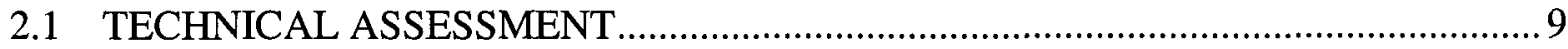

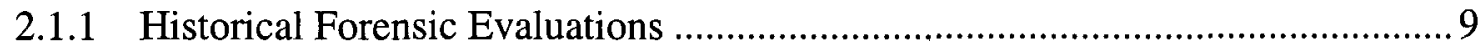

2.1.2 Forensic Evaluation Software .................................................................... 10

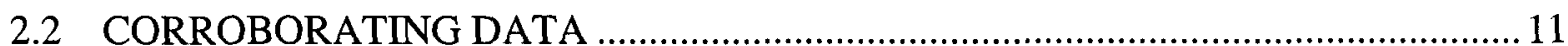

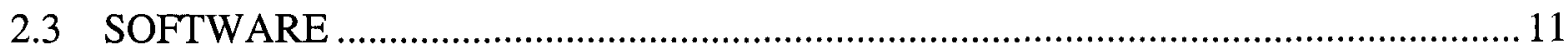

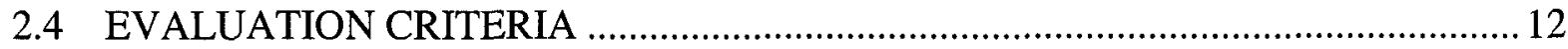

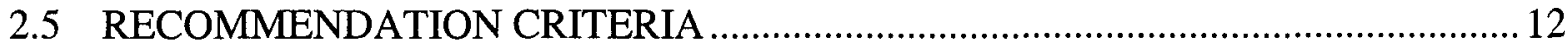

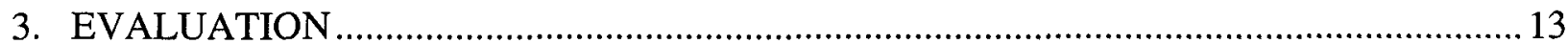

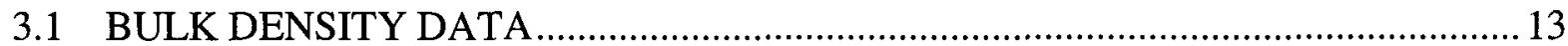

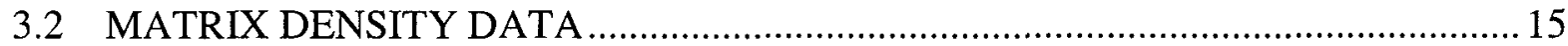

3.3 NEUTRON DATA AND VOLUMETRIC WATER CONTENT ………………...........17

3.4 FORENSIC ANALYSES: UE-25 p\#1 AND USW H-6 ............................................ 18

3.5 CORROBORATION OF CORE POROSITY WITH TOTAL POROSITY DATA ..... 20

3.5.1 Corroboration of the Modern Borehole Data ……........................................... 20

3.5.2 Corroboration of Historical Input Data with Modern Input Data ...................... 28

3.5.3 Porosity Log Technical Assessment and Corroboration ………………..............32

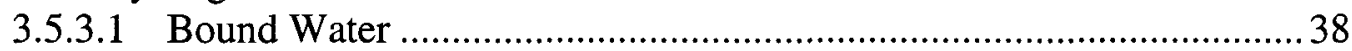

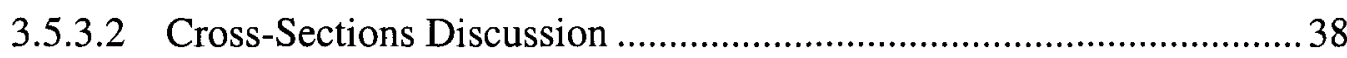

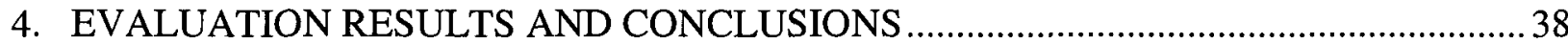

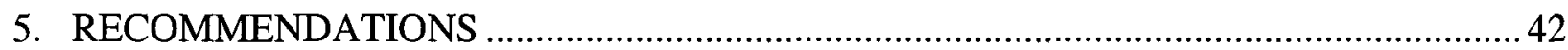

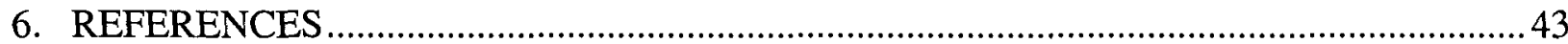

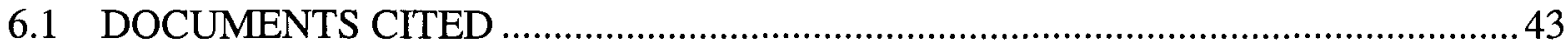

6.2 CODES, STANDARDS, REGULATIONS, AND PROCEDURES ………………......4 48

6.3 SOURCE DATA, LISTED BY DATA TRACKING NUMBER ...................................4 48

6.4 OUTPUT DATA, LISTED BY DATA TRACKING NUMBER …...............................5 
APPENDIX A - Example Input Data Sheets for Geophysical Data, Core Density and XRD Data used in Porosity Calculations, and Core Porosity Data....

APPENDIX B - Forensic Evaluation Excerpts for USW H-6 and UE-25 P\#1

APPENDIX C - Comparison of Old and Modern Inputs and Outputs for Historical Wells

\section{FIGURES}

Figure 1. Idealized Response of Bulk Density Data in Tptrv1, Tptrn, Tptpmn, and Tptpv3 14

Figure 2. Computed Total Porosity and Core Data USW SD-7 ........................................2 21

Figure 3. Computed Total Porosity and Core Data USW SD 12 .........................................22

Figure 4. Computed Total Porosity and Core Data USW SD-9 ............................................23

Figure 5. Computed Total Porosity and Core Data UE-25 UZ\#16 .....................................24

Figure 6. Computed Total Porosity and Core Data USW NRG 7A ......................................25

Figure 7. Cross-Plot of Core Porosity and Porosity Computed from Logs ............................. 27

Figure 8. Comparison of Porosity Results Using Old and Modern Data Sets for USW

Figure 9. Comparison of Porosity Results Using Old and Modern Data Sets for USW

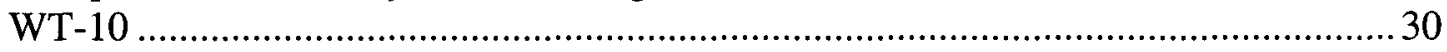

Figure 10. Comparison of Porosity results Using Old and Modern Data Sets for UE-25

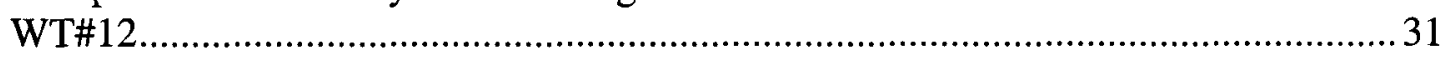

Figure 11. Comparison of Porosity Results Using Old and Modern Data Sets for USW WT-2

Figure 12. Generalized Borehole Locations

Figure 13. Generalized Diagnostic Changes in Calculated Porosity at Selected Lithologic Intervals with Depth (in feet)

\section{TABLES}

Table 1. Boreholes Used in Generating Computed Porosity Values ....................................... 3

Table 2. Formation Density $(\mathrm{gm} / \mathrm{cc})$ Averages from Core and XRD Data ........................... 16

Table 3. Borehole Logs Included in Cross-Section Plates A-K from Rael (1999) .................. 33 


\section{ACRONYMS AND ABBREVIATIONS}

$\begin{array}{ll}\text { AMR } & \text { Analysis/Model Report } \\ \text { BGTA } & \text { Borehole Geophysical Technical Assessment } \\ \text { CRWMS } & \text { Civilian Radioactive Waste Management System } \\ \text { DOE } & \text { U.S. Department of Energy } \\ \text { DTN } & \text { Data Tracking Number } \\ \text { ECN } & \text { Expedited Change Notice } \\ \text { ICN } & \text { Interim Change Notice } \\ \text { IMTPID } & \text { Integrated Management of Technical Product Inputs Department } \\ \text { M\&O } & \text { Management and Operating Contractor } \\ \text { PVAR } & \text { Process Validation and Re-engineering } \\ \text { QAPP } & \text { Quality Assurance Program Plan } \\ \text { QARD } & \text { Quality Assurance Requirements Document } \\ \text { STN } & \text { Software Tracking Number } \\ \text { TDMS } & \text { Technical Data Management System } \\ \text { USGS } & \text { U.S. Geological Survey } \\ \text { WIPP } & \text { Waste Isolation Pilot Plant } \\ \text { XRD } & \text { X-Ray Diffraction } \\ \text { YMNTS } & \text { Yucca Mountain NT Server } \\ \text { YMP } & \text { Yucca Mountain Site Characterization Project }\end{array}$




\section{INTRODUCTION}

\subsection{PURPOSE}

The qualification is being completed in accordance with the Data Qualification Plan DQP-NBSGS-000006, Rev. 00 (CRWMS M\&O 2001). The purpose of this data qualification activity is to evaluate for qualification the unqualified developed input and porosity output included in Data Tracking Number (DTN) MO9910POROCALC.000. The main output of the analyses documented in DTN MO9910POROCALC.000 is the calculated total porosity and effective porosity for 40 Yucca Mountain Project boreholes.

The porosity data are used as input to Analysis/Model Report (AMR) I0040, Rock Properties Model (MDL-NBS-GS-000004, Rev. 00, Interim Change Notice [ICN] 02 (CRWMS M\&O $2000 \mathrm{~b}$ ). The output from the rock properties model is used as input to numerical physical-process modeling within the context of a relationship developed in the AMR between hydraulic conductivity, bound water and zeolitic zones for use in the unsaturated zone model. In accordance with procedure AP-3.15Q, the porosity output is not used in the direct calculation of Principal Factors for post-closure safety or disruptive events.

The original source for DTN MO9910POROCALC.000 is a Civilian Radioactive Waste Management System (CRWMS) Management and Operating Contractor (M\&O) report, Combined Porosity from Geophysical Logs (CRWMS M\&O 1999a and hereafter referred to as Rael 1999). That report recalculated porosity results for both the historical boreholes covered in Nelson (1996), and the modern boreholes reported in CRWMS M\&O (1996a,b).

The porosity computations in Rael (1999) are based on density-porosity mathematical relationships requiring various input parameters, including bulk density, matrix density and air and/or fluid density and volumetric water content. The main output is computed total porosity and effective porosity reported on a foot-by-foot basis for each borehole, although volumetric water content is derived from neutron data as an interim output.

This qualification report uses technical assessment and corroboration to evaluate the original subject DTN. Rael (1999) provides many technical details of the technical assessment and corroboration methods and partially satisfies the intent of the qualification plan for this analysis. Rael presents a modified method based on Nelson (1996) to recompute porosity and porosityderived values and uses some of the same inputs. Rael's (1999) intended purpose was to document porosity output relatively free of biases introduced by differing computational methods or parameter selections used for different boreholes. The qualification report necessarily evaluates the soundness of the pre-Process Validation and Re-engineering (PVAR) analyses and methodology, as reported in Rael (1999).

The porosity results calculated for "historical" boreholes drilled and tested prior to 1991 have several quality-affecting issues, including:

- Unqualified composite neutron geophysical logs used in the porosity calculations that were created by the U.S. Geological Survey (USGS) before or outside the approved 
USGS Quality Assurance Program Plan (QAPP) for the Yucca Mountain Site Characterization Project (YMP)

- The methodologies and professional judgement used to manipulate and produce the porosity results in Nelson (1996) were not sufficiently documented.

The porosity results calculated for the modern boreholes, and those from geophysical logs rerun in historical holes, have several positive quality-affecting attributes:

- Modern logs were calculated from qualified geophysical logs that were collected and developed in accordance with approved YMP procedures under the U.S. Department of Energy (DOE) Quality Assurance Requirements and Description document (QARD).

- All modern boreholes have undergone forensic analyses, a process that verifies the accuracy of the original borehole logging data and the corresponding DTNs are qualified (CRWMS M\&O $1996 \mathrm{c}$ through n; CRWMS M\&O $1999 \mathrm{~b}$ and c).

The Data Qualification Team found no unique deficiencies associated with the calculated porosity results for the historical or modern borehole data sets reported by the USGS.

Unqualified software version QLA V2.2, Software Tracking Number (STN): 10082-2.2-00 (CRWMS M\&O 2000c) used by Rael (1999) in both the historical and modern porosity calculătions is now qualified. Using the unqualified and qualified versions of the software and using the same input parameters, application of software qualification AP-SI.1Q, Section 5.11.3.c showed no differences in the output other than round-off error that did not impact the results.

\subsection{SCOPE}

The scope of this data qualification activity is to evaluate unqualified developed input and porosity output included in DTN MO9910POROCALC.000. The scope of this report is not to qualify all of the data used in the analyses by Rael (1999). Rather, it is intended that output results be qualified and used to substantiate the developed input included in the two DTNs developed for this qualification activity: DTNs MO0010CPORGLOG.002 and MO0010CPORGLOG.003. These two DTNs supersede MO09910POROCALC.000 only in that the boreholes are divided into historical and modern borehole data sets as shown in Table 1 and that data for USW SD-6 and USW WT-24 have been added to DTN MO0010CPORGLOG.003. 
Table 1. Boreholes Used in Generating Computed Porosity Values

\begin{tabular}{|c|c|c|c|c|}
\hline Boreholes & Pedigree & $\begin{array}{l}\text { Data Tracking Number } \\
\text { Historical Geophysical } \\
\text { Inputs (Nelson, 1996) }\end{array}$ & $\begin{array}{c}\text { Qualified Historical Log } \\
\text { Data }\end{array}$ & $\begin{array}{c}\text { Qualified Modern } \\
\text { Geophysical Input Data }\end{array}$ \\
\hline USW G-1 & Historical & MO0003COMPLOGS.000 & MO960408314213.021 & \\
\hline USW G-2 & Historical & MO0003COMPLOGS.000 & MO960408314213.022 & $\begin{array}{l}\text { Modern logs also run } \\
\text { MO9906GEOUSWG2.000 }\end{array}$ \\
\hline $\begin{array}{l}\text { USW G- } \\
\text { 3/USW GU-3 }\end{array}$ & Historical & MO0003COMPLOGS.000 & $\begin{array}{l}\text { MO960408314213.023 } \\
\text { MO960408314213.025 }\end{array}$ & $\begin{array}{l}\text { (Note - USW G-3/GU3 } \\
\text { Combined) }\end{array}$ \\
\hline USW G-4 & Historical & MO0003COMPLOGS.000 & MO960408314213.024 & \\
\hline USW H-1 & Historical & MO0003COMPLOGS.000 & MO960408314213.026 & \\
\hline USW H-3 & Historical & MO0003COMPLOGS.000 & MO960408314213.027 & \\
\hline USW H-4 & Historical & MO0003COMPLOGS.000 & MO960408314213.028 & \\
\hline USW H-5 & Historical & MO0003COMPLOGS.000 & MO960408314213.029 & \\
\hline USW $\mathrm{H}-6$ & Historical & MO0003COMPLOGS.000 & MO960408314213.030 & \\
\hline UE-25 NRG\#4 & Modern & & & MO9906GEOLNRG4.000 \\
\hline UE-25 NRG\#5 & Modern & & & MO9906GEOLNRG5.000 \\
\hline USW NRG-6 & Modern & & & MO9906GEOLNRG6.000 \\
\hline USW NRG-7A & Modern & & & MO9906GENRG77A.000 \\
\hline UE-25 ONC\#1 & Modern & & & MO9906GEOLONC1.000 \\
\hline UE-25 P\#1 & Historical & MO0003COMPLOGS.000 & MO960408314213.010 & \\
\hline USW SD-6 & Modern & & & MO9911GEOLOSD6.001 \\
\hline USW SD.7 & Modern & & & MO9907GEUSWSD7.000 \\
\hline USW SD-9 & Modern & & & MO9906GEOLOSD9.000 \\
\hline USW SD-12 & Modern & & & MO9907GUSWSD12.000 \\
\hline USW UZ-1 & Historical & MO0003COMPLOGS.001 & & \\
\hline UE-25 UZ\#4 & Modern & & & MO9907GUE25UZ4.000 \\
\hline UE-25 UZ\#5 & Modern & & & MO9907GUE25UZ5.000 \\
\hline USW UZ-6 & Historical & MO0003COMPLOGS.001 & & \\
\hline USW UZ-7A & Modern & & & MO9907GUSWUZ7A.000 \\
\hline USW UZ-14 & Modern & & & MO9908GEOLUZ14.000 \\
\hline UE-25 UZ\#16 & Modern & & & MO9907UE25UZ16.000 \\
\hline USW WT-1 & Historical & MO0003COMPLOGS.000 & MO960408314213.035 & \\
\hline USW WT-2 & Historical & MO0003COMPLOGS.000 & MO960408314213.036 & $\begin{array}{l}\text { Modern logs also run } \\
\text { MO9907GEUSWWT2.000 }\end{array}$ \\
\hline UE-25 WT\#3 & Historical & MO0003COMPLOGS.000 & MO960408314213.011 & \\
\hline UE-25 WT\#4 & Historical & MO0003COMPLOGS.000 & MO9604083314213.012 & \\
\hline UE-25 WT\#6 & Historical & MO0003COMPLOGS.000 & MO960408314213.013 & \\
\hline USW WT-7 & Historical & MO0003COMPLOGS.000 & M0960408314213.037 & \\
\hline USW WT-10 & Historical & & MO960408314213.038 & $\begin{array}{l}\text { Modern logs also run } \\
\text { MO9908GEUSWT10.000 }\end{array}$ \\
\hline USW WT-11 & Historical & MO0003COMPLOGS.000 & MO960408314213.039 & \\
\hline UE-25 WT\#12 & Historical & & MO960408314213.014 & $\begin{array}{l}\text { Modern logs also run } \\
\text { MO9908GEOLWT12.000 }\end{array}$ \\
\hline UE-25 WT\#13 & Historical & MO0003COMPLOGS.000 & MO960408314213.015 & \\
\hline UE-25 WT\#14 & Historical & MO0003COMPLOGS.000 & MO960408314213.016 & \\
\hline UE-25 WT\#15 & Historical & MO0003COMPLOGS.000 & MO960408314213.017 & \\
\hline UE-25 WT\#16 & Historical & MO0003COMPLOGS.000 & MO960408314213.018 & \\
\hline UE-25 WT\#17 & Historical & MO0003COMPLOGS.000 & MO960408314213.019 & \\
\hline UE-25 WT\#18 & Historical & MO0003COMPLOGS.000 & MO960408314213.020 & \\
\hline USW WT-24 & Modern & & & MO9911GEOLWT24.001 \\
\hline
\end{tabular}

1) Listed DTNs provide bulk density and some qualified neutron composite logs used in Rael (1999). DTN MO0105CPORGLOG.004 includes all neutron data used in Rael's (1999) porosity calculations and will be qualified as part of this qualification activity. 
This qualification report includes the modern and historical boreholes shown in Table 1. The pedigree designation "modern" means that geophysical input data acquisition occurred under the QARD. Modern geophysical input data are contained in the qualified DTNs listed in the far right-hand column of Table 1 . Table 1 identifies four historical boreholes as having qualified geophysical inputs: USW G-2, USW WT-2, USW WT-10, and UE-25 WT\#12. Porosity calculations for these boreholes relied on modern geophysical input data that were reacquired under the QARD, using historical geophysical data only at depths or intervals containing no modern data (i.e., USW G-2: modern data above 2161 feet and historical data below 2161 feet in the borehole). All modern geophysical input data DTNs have been subject to forensic evaluation (CRWMS M\&O 1996c through n; CRWMS M\&O 1999b and c).

Appendix A contains sample geophysical data input sheets selected from Rael (1999, Appendix C) for two boreholes supported by modern geophysical input data: UE-25 UZ-5 and USW WT-2; Appendix A, Tables A1 and A2, respectively. The qualified modern geophysical input data DTNs listed in Table 1 are shown as the sources of the geophysical data in the data input sheets (i.e., UE-25 UZ-5, MO9907GUE25UZ5.000; USW WT-2, MO9907GUESWWT2.000). Appendix A also contains examples of historical borehole data input sheets (e.g., UE-25 p\#1, USW H-6 and USW G-1, Appendix A; Tables A3, A4 and A5, respectively). As described above, the historical borehole USW WT-2 is supported by qualified modern geophysical input and unqualified historical data, specifically unqualified neutron data contained in DTN MO0105CPORGLOG.004.

To recalculate porosity calculations involving historical boreholes, Rael (1999) used historical geophysical composite and run logs from Nelson (1996). Geophysical data input sheets from Rael (1999; Appendix C) are included in Appendix A for three selected historical boreholes USW G-1, USW H-6, and UE-25 p\#1. As apparent from these data sheets, geophysical data from Nelson (1996) were not available from the Technical Data Management System (TDMS) at the time of Rael's porosity calculations. For traceability purposes, Rael (1999) provided a file path to the YMP Yucca Mountain NT Server (YMNTS) network drive containing the uncontrolled geophysical data. The files used by Rael (1999) have subsequently been submitted by the USGS to the TDMS.

The Data Qualification Team has verified the YMNTS network drive inputs with the USGS data submitted to the TDMS. Some qualified composite neutron porosity logs and all qualified bulk density logs used by Rael (1999) are currently contained in DTNs MO0003COMPLOGS.000, MO0003COMPLOGS.001 (Table 1). Neutron porosity logs and bulk density logs are the primary geophysical inputs used in the porosity calculations. DTNs MO0003COMPLOGS.000 and MO0003COMPLOGS.001also include an assemblage of other composite geophysical logs from Nelson (1996), including caliper logs, gamma intensity and resistivity data. These data are not primary inputs to porosity calculations, but rather are used to calibrate inputs and/or are part of the Nelson (1996) methodology adopted and documented by Rael (1999).

A Borehole Geophysical Technical Assessment (BGTA) Team established procedural equivalence for much of the geophysical data contained in the above qualified DTNs (CRWMS 
M\&O 1995, CRWMS M\&O 19960, CRWMS M\&O 1999d). The DTNs associated with the BGTA qualification checklists are identified in Table 1 (e.g. USW G-1 MO960408314213.021). The BGTA qualification activity qualified the majority of historical geophysical run logs and composite logs, including the bulk density logs used by Nelson (1996) in DTNs MO0003COMPLOGS.000 and MO0003COMPLOGS.001. Other composite logs incorporated into DTNs MO0003COMPLOGS.000 and MO0003COMPLOGS.001 were qualified in a qualification report, Composite Geophysical Logs (CRWMS M\&O 2000a).

Selected neutron porosity data used by Nelson (1996) were not qualified in the above qualification activities. Rael (1999) used selected unqualified neutron data from Nelson (1996) to compile the neutron porosities used in his porosity calculations. DTNs MO0010CPORGLOG.002 and MO0010CPORGLOG.003 include the selected unqualified neutron porosity. DTN MO0105CPORGLOG.004 contains the original USGS unqualified neutron porosity data. Neutron data contained in all the above unqualified DTNs created as part of this qualification activity will be qualified as part of this report.

For traceability purposes, Appendix A also contains a list of core density and X-Ray Diffraction (XRD) data used to develop matrix density inputs subject to qualification identified in the DTNs MO0010CPORGLOG.002 and MO0010CPORGLOG.003; Appendix A, Tables A6 and A7, respectively. Some of the XRD data used primarily in the historical borehole calculations are unqualified. In addition, core density data for one of the boreholes listed in Appendix A, Table A6 is unqualified. However, laboratory-measured core densities and mineralogical data used in the Rael (1999) analyses are not within the scope of this qualification. Matrix densities developed as part of the porosity calculations will be substantiated based on the corroboration and technical assessment of the output.

\subsection{BACKGROUND}

The porosity model adopted by Rael $(1999$, pg. $5-1)$ is a modified method of that employed by Nelson (1996) to compute total porosity. The Rael (1999) report provides a detailed explanation of the methodology only summarized in this qualification report. The explanation below is intended to provide the context for the technical discussion presented in Section 3.0 "Evaluation."

Nelson (1996) presented the general relationship between density data and porosity (Asquith and Gibson 1982, p. 67):

$$
\begin{aligned}
\phi_{\mathrm{t}}=\left[\frac{\rho_{\mathrm{ma}}-\rho_{\mathrm{b}}}{\rho_{\mathrm{ma}}-\rho_{\mathrm{f}}}\right] & \\
\text { Where: } & \quad \text { (General Form) } \\
\phi_{\mathrm{t}} & =\text { Total Porosity }(\%) \\
\rho_{\mathrm{b}} & =\text { Bulk Density }\left(\mathrm{g} / \mathrm{cm}^{3}\right) \\
\rho_{\mathrm{ma}} & =\text { Matrix Density }\left(\mathrm{g} / \mathrm{cm}^{3}\right) \\
\rho_{\mathrm{f}} & =\text { Fluid Density }\left(\mathrm{g} / \mathrm{cm}^{3}\right)
\end{aligned}
$$


Based on a review of Nelson's (1996) methodology, Rael (1999) examined the input parameters and recomputed porosities for historical and modern boreholes using the following equations, depending on the availability and quality of data in a borehole and whether the porosity was being calculated in the saturated or unsaturated zone. As presented in Rael (1999, Appendix G), total porosity is generally calculated in the unsaturated zone as:

$$
\begin{array}{rlr}
\text { PHIDAIR } & =\underline{\text { GRNDEN }- \text { RHOBED }} & \text { (Unsaturated) }
\end{array}
$$

Where:

PHIDAIR is total porosity assuming air-filled voids in unsaturated zone

GRNDEN (grain density) is equivalent to matrix density and is calculated using various data (ie. grain density from core data, particle density data derived from XRD analyses of cores and cuttings, and densities obtained from correlation). Where core data are available, GRNDEN is modified to calculate effective porosities or total porosities: effective porosities using core dried at $65^{\circ} \mathrm{C}, 60$ percent relative humidity and total porosity using oven-dried core at $105^{\circ} \mathrm{C}$. The two different types of matrix densities corresponding to the relative humidity and oven-dried measurements, respectively, are discussed in more detail in Section 3.2 of this report. The reader is referred to appendices in Rael (1999; Appendices $\mathrm{E}, \mathrm{F}, \mathrm{G})$ for a detailed description of the derivation of GRNDEN for each individual borehole.

RHOBED is the corrected and edited bulk density data obtained from bulk density logs. The process is discussed in detail in Rael (1999, pg. 4-2) and is summarized in Section 3.1 of this report.

AIR_DENSITY is the fluid density assumed to be that of dry air, approximately 0.001223 gm/cc (Gearhart 1970, p. 33). This assumption is verified by Rael (1999, pg. 5-1).

Rael (1999, Appendix G) provides the following total porosity calculation for the saturated zone:

$$
\text { (Saturated) } \quad \text { Eq. } 3
$$

$$
\text { NELPOR }=\frac{\text { GRNDEN }- \text { RHOBED }+ \text { VWC } *(\text { FLUID DEN-AIR_DENSITY) }}{\text { GRNDEN }- \text { AIR_DENSITY }}
$$

Where:

NELPOR is the parameter name assigned in Rael (1999) to total porosity calculations calculated for the saturated zone.

GRNDEN, RHOBED and AIR_DENSITY are the same as above. 
VWC is the volumetric water content obtained from neutron data and equivalent to waterfilled porosity

FLUD_DEN is the fluid density of water (assumed to be $1.00 \mathrm{gm} / \mathrm{cc}$ )

Rael (1999, Appendix G) shows borehole-by-borehole the methodology and equations used to select input parameters. The output is presented in the TDMS as a series of tables for each borehole: porosity (total porosity), effective porosity, and volumetric water content. Inputs developed by Rael (1999) are also shown: an edited neutron porosity, a corrected bulk density, and two matrix densities used for calculating total and effective porosities. In the TDMS, the data are shown for identified depth intervals in each borehole. Rael (1999) presents the data in a series of plates containing boreholes logs of input and output along lines of section of two or more boreholes. This side-by-side visualization of the data allows lateral continuity to be assessed within a lithostratigraphic context.

\subsection{DATA QUALIFICATION TEAM}

The Responsible Manager for this data qualification task is Robert Wemheuer (Integrated Management of Technical Product Inputs Department [IMTPD] Manager).

This data qualification activity requires professional geophysical skills with experience in Yucca Mountain lithostratigraphy and expertise in geophysical log interpretation, subsurface geology, volcanic stratigraphy, or combination thereof, with a minimum of five years relevant professional experience.

\section{Chairperson}

Clinton Lum: Dr. Lum has a Ph.D. in Geology from Rice University, Houston, Texas, and over 7 years of experience in varied geoscience projects. He spent four years working for a major oil company and performed a variety of duties including kerogen and basin modeling, oil exploration, and drilling operations and support. He has 4 years of experience on the YMP in geology, drilling, construction monitoring, and geochemistry. Dr. Lum was not part of the YMP during the period of time when the logs to be qualified were recorded and processed and has not participated in previous geophysical activities on the Project.

\section{Technical Advisor}

Howard Rael: Mr. Rael has a Mineral Engineer-Mathematics degree from the Colorado School of Mines and over 23 years industry experience as both a logging engineer and a petrophysicist. He also completed Amoco's yearlong petrophysics course at their Tulsa research center. His experience includes planning logging programs, conducting logging operations and analyzing borehole data. Mr. Rael has been involved in the collection and processing of recent geophysical information for the YMP, but he was not part of the Project during the period of time when the logs to be qualified were recorded and processed. 
Mr. Rael is included on the Data Qualification Team because of his experience with recent geophysical logging programs. As author of the subject report that developed DTN MO9910POROCALC.000, he provides a valuable reference for this qualification. As a geophysicist who has many geophysical forensic and logging projects on the YMP, he also provides insight into the technical quality of older geophysical logs which pre-date current quality assurance procedures.

Due to Mr. Rael's involvement in the development of the DTN, per AP-SIII.2Q, Section 5.1.4 the qualification plan clarifies Mr. Rael's role as solely a technical advisor. The actual assessment and determination on whether the DTN should be qualified is implemented independently by the actual members of the Data Qualification Team. There is no conflict of interest in Mr. Rael's involvement.

\section{Technical Representatives}

William Zelinski : As stated in the qualification plan DQP-NBS-GS-000006, Rev. 00 (CRWMS M\&O, 2001), Mr. Zelinski was to conduct technical work for this qualification activity. Mr. Zelinski subsequently left the project before conducting any technical work.

Paul Sanchez : Mr. Sanchez performed the data qualification and prepared this report. He has an M.S. degree in geology from Northern Arizona University and over 16 years experience in engineering geology, including 7 years conducting geologic and geotechnical site investigations, geotechnical laboratory analyses, and seismic hazard analyses. Mr. Sanchez has over 9 years experience in the development of data and input parameters for process modeling and performance assessment modeling for the Waste Isolation Pilot Plant (WIPP) and YMP. Projects include flow and transport modeling and geomechanical modeling. Mr. Sanchez has completed or been involved in numerous AP-SIII.2Q qualification activities and has had no involvement with the collection or processing of this data.

\section{QUALIFICATION METHODS}

The methodology includes a combination of technical assessment and corroboration of calculated porosity results and selected input to the porosity calculations. Essential components of the qualification include:

- Key sections of Rael (1999) are summarized with pointers to the sections in Rael (1999) that document the methodology employed to recalculate Nelson's (1996) porosity calculations and developed inputs. The summaries represent an AP-SIII.2Q technical assessment of Rael's (1999) methodology.

- Use of forensic evaluations for two historical boreholes (USW H-6 and UE-25 p\#1) and an associated software qualification that provides additional documentation and reproducibility of the Nelson (1996) methodology, including the selection of neutron data for boreholes. 
- Reproduction of the neutron data and correlation developed between neutron porosity and other measured borehole parameters (e.g. bulk density) in the forensic evaluations of the historical boreholes.

- Visual corroboration of the modern data set based on a comparison of core porosities and geophysical-based porosities evident from plots of five modern boreholes.

- Comparison of all geophysical-based porosities and core porosities for each stratigraphic interval using historical and modern logs

- Comparison of modern and historical geophysical porosity results for four boreholes (USW G-2, USW WT-2, USW WT-10, and UE-25 WT \#12) generated by historical and modern inputs available for these wells. This comparison augments the technical assessment involving the forensic analyses of USW H-6 and UE-25 p\#1 and further substantiates the adequacy of developed inputs and the porosity calculations.

- Assessment of the geologic continuity of stratigraphic sequences from borehole to borehole inferred from porosity logs and stratigraphic intervals shown in cross-sections in Rael (1999).

Overall, the combined methodologies summarized above are designed to address porosity results calculated for modern boreholes and to validate the main developed inputs used in the calculations. The cumulative assessment is also designed to substantiate input and calculated porosities for historical boreholes, in which the developed input and output relied on the same methodology as the modern boreholes.

\subsection{TECHNICAL ASSESSMENT}

This qualification report uses selected excerpts from Rael (1999) to summarize the methodology and selection of input parameters discussed in Section 1.3. Excerpts from Rael (1999) are paraphrased in Section 3.1 (Bulk Density), Section 3.2 (Matrix Density) and Section 3.3 (Neutron Data and Volumetric Water Content). These are the primary input parameters used in the calculation of effective and total porosity. This section is intended to document the Nelson (1996) and Rael (1999) methodologies and support the qualification of the primary input parameters.

\subsubsection{Historical Forensic Evaluations}

As part of the technical assessment, the Data Qualification Team reviewed preliminary results of forensic evaluations for two historical boreholes USW H-6 and UE-25 p\#1. Forensic evaluations are designed to reproduce and confirm geophysical compositing and computational methods. Forensic evaluations are also designed to verify the accuracy of geophysical log data. Originally planned as part of this qualification, the forensic evaluations are being completed separately and are identified as: 
- MIS-NBS-GE-000002, Forensic Evaluation of Geophysical Log Data and Qualification of Geophysical Log Data for Borehole USW H-6, (Olsen and Rael 2001).

- MIS-NBS-GE-00001, Forensic Evaluation of Geophysical Log Data and Qualification of Geophysical Log Data for Borehole UE-25 P\#1, (Rael 2001).

The Data Qualification Team has found that the forensic evaluations have undergone all appropriate technical reviews and are awaiting only administrative submittal. The procedures applied to the forensic evaluations include:

- NWI-GL-001Q, Rev. 0, ICN 1, Verification and Processing of Geophysical Log Data

- NWI-GL-002Q, Rev. 0, ICN 2, Forensic Evaluation of Geophysical Log Data

- NWI-GL-003Q, Rev. 0, ICN 2, Analysis of Geophysical Log and Associated DepthRelated Borehole Data.

Based on technical review of the draft reports, relevant portions from the two forensic evaluations found to support this qualification activity have been summarized and incorporated into this qualification report (Appendix B). Only relevant text and figures are extracted, such as correlation between neutron and other co-measured geophysical data (e.g. density and gamma curves) and correlation between forensic reconstruction of the neutron data and neutron data created by Nelson (1996). The forensic evaluations for these two boreholes are discussed in Section 3.4.

As originally intended, UE-25 p \#1 was chosen because the borehole is the deepest of all historical boreholes and the only one to penetrate the Paleozoic basement. USW H-6 was chosen because it is a prominent rotary borehole important to hydrologic investigations. Logging companies Birdwell and Dresser-Atlas acquired geophysical data in all historical boreholes and also logged USW H-6 and UE-25 p\#1 (Table 1). Consequently, geophysical measurements in both boreholes are representative of the standard drilling practices employed during the early 1980's.

By duplicating the compositing process and computational methods used by Nelson (1996), forensic evaluation results support the qualification of the historical composite logs and the neutron porosity computations created by Nelson (1996). The forensic evaluations for these two wells also support documentation of the Nelson (1996) methodology, as adopted by Rael (1999).

\subsubsection{Forensic Evaluation Software}

A macro created in visual basic (NUE_POR, Version 0, STN: 10488-0-00) for the forensic evaluation of the two historical boreholes is used to duplicate undocumented procedures used by Nelson (1996), including data selection (e.g. to sele*/ct appropriate neutron data) and methods to interpolate neutron data within the borehole. NEU_POR Version 0 supports this data qualification through corroboration by documenting and reproducing the Nelson (1996) methodology to determine the neutron porosities used by Rael (1999) in the porosity calculations. This software (STN: 10488-0-00) is addressed by reference only in this qualification report. 


\subsection{CORROBORATING DATA}

Section 3.5 includes all of the following corroborating approaches used in this qualification activity.

Rael (1999) compared geophysical-based porosities and core measured-porosities for five modern boreholes USW SD-7, USW SD-9, USW SD-12, UE-25 UZ\#16 and USW NRG-7A. The set of figures from Rael (1999) is reproduced in Section 3.5.1 in the context of a visual corroboration of the modern data. Additional corroboration is presented Section 3.5.1 involving a quantitative comparison of modern geophysical-based and core porosity data. Porosity values obtained from core samples and logs are averaged at stratigraphic intervals specified by Rael (1999) and compared.

Modern measurements were conducted in several historical boreholes, including USW G-2, USW WT-2, USW WT-10, and UE-25 WT\#12. This allows comparison of modern and historical geophysical porosity results using input from the modern data set and the corresponding historical data set (Section 3.5.2). The degree of agreement or differences should be attributed solely to the input parameters, and consequently, can be used to validate the historical Nelson (1996) input used by Rael (1999). Combined with the two forensic evaluations (Section 3.4), corroboration of the historical data in these four historical wells increases to six the total number of potentially validated historical boreholes. This comparison further substantiates the adequacy of all primary historical geophysical inputs and the porosity calculations. In addition, use of similar methodologies to derive the historical and modern data set porosity results support the historical data set porosity results.

Layers of rock having different properties in layered stratigraphic sequences show deviations in physical properties with depth. Diagnostic lithostratigraphic intervals should show horizontal and/or vertical continuity along an undisturbed line of section. Rael (1999) presents geophysical borehole logs along lines of section in oversize plates included in his report. In Section 3.5.3, the Data Qualification Team reviewed these plates for continuity and consistency with adjacent borehole logs, as well as consistency with regional geology. Comparison of data from borehole to borehole invokes an element of corroboration; however, the approach includes both technical assessment and corroboration.

\subsection{SOFTWARE}

The unqualified software version QLA V2.2 (CRWMS M\&O 2000c) used in the Rael (1999) computations is now qualified. This same qualified version was used in all the forensic analyses to construct and merge the composite logs, including the most recent evaluations on the two historical boreholes. Qualified software version QLA V2.2 (CRWMS M\&O 2000c) obtained from the software baseline is used in this report to graphically display modern and historical data sets for visual corroboration.

Microsoft Excel software is used in this report to perform spreadsheet calculations to evaluate similarities and differences among data sets. The graphical components of Excel are also used to display the data as cross-plots. Use of this software is exempt from the requirements of 
procedure AP-SI.1Q because it is used only for visual display and graphical representation of data.

\subsection{EVALUATION CRITERIA}

The criteria considered to evaluate the developed input and output from the porosity calculations for qualification are identified below. These criteria are applied by the chairperson and team members and are independent of Mr. Rael's involvement as an advisor to this qualification activity.

1. Are the geophysical logs and other input parameters used in porosity calculations documented?

2. Are the methods for determining porosity and porosity-derived values reproduced and documented?

3. Are resulting porosity and porosity-derived values as presented in Rael (1999) corroborated or technically justified as representing the properties of interest?

4. Does the porosity/porosity-derived output from DTN MO9910POROCALC.000, presented in Rael (1999) as a series of cross-sections, show lateral lithostratigraphic continuity with adjacent boreholes?

5. Are measured porosity values from core consistent with geophysical porosity logs?

6. Do the forensic analyses of the historical boreholes reproduce Nelson (1996) neutron porosity data?

7. Do the forensic analyses of the historical boreholes document the data manipulation used to create composite geophysical logs?

\subsection{RECOMMENDATION CRITERIA}

DTNs MO0010CPORGLOG.002 and MO0010CPORGLOG.003 currently contain the developed inputs and output from Rael's (1999) report. These DTNs separate the historical and modern borehole data sets contained in the original DTN MO9910POROCALC.000. As stated, both generations of data sets are discussed interchangeably in this report; however, only the superseding DTNs will be subject to recommendations for qualification.

The criteria to recommend qualification of the output of the porosity calculations and associated input include the cumulative assessment of the evaluation criteria, including the technical and corroborative assessments. Consequently, recommendation criteria are necessarily broad, and recommendations will be based on the preponderance of the evidence determined by the cumulative responses to the evaluation criteria in Section 2.4.

DTN MO0105CPORGLOG.004 was created for this qualification activity to contain additional unqualified neutron data from Nelson (1996) that, along with bulk density, are the primary geophysical parameters used in the porosity calculations. Criteria to recommend qualification of this selected input are provided by evaluation criteria 6 and 7 in Section 2.4. 


\section{EVALUATION}

Accurate porosities computed from geophysical logging data depend on the accuracy of the downhole measurements and the input parameters used in the computations. The input parameters consist of the bulk density and matrix density of the rocks and the density of the fluid (air or water) occupying the pore space.

Prior to the computations, Rael (1999) checked the input density and neutron data in stratigraphic zones where little variance in recorded values was observed from borehole to borehole. These zones provided a method of determining calibration accuracy using down hole response, without eliminating actual lateral changes in rock parameters.

Neutron data were less consistent than density data since various types of equipment were used over the years. Most of the neutron data in the historical boreholes were collected using older, single detector equipment that provided detector count rates only. This data had to be converted to porosity using a calibration method developed by Nelson (1996, pg. 9-14).

\subsection{BULK DENSITY DATA}

The data supplied by formation bulk density tools provide the most important information for porosity calculations. Density data are typically recorded in grams/cubic centimeter $(\mathrm{gm} / \mathrm{cc})$ but some of the earlier tools provided measurements in counts per second and had to be converted to gm/cc. Rael (1999, pg. 1-1) reported that the formation density tools used for historical boreholes were operationally equivalent to those used in modern boreholes without regard to vendor or modification of basic tool design.

To verify calibration of the bulk density tools for historical boreholes, Rael (1999, pg. 4-2) checked tool response in zones that show consistent values from borehole to borehole. Four such zones exist in most YMP boreholes. They are the crystal-rich vitric zones (Tptrv1) near the top of the Topopah Spring member, the crystal-rich nonlithophysal zone (Tptrn), the middle nonlithophysal zone (Tptpmn) and the crystal-poor vitric zones (Tptpv3) near the base of the Topopah Spring.

Figure 1 is the idealized response of the bulk density tool in a typical YMP borehole. This plot was generated by establishing an average value through these zones using merged data from USW G-1, USW SD-7, USW SD-9, and UE-25 UZ\#16. Rael (1999, pg. 4-2) used this "idealized" response to check the calibration in the remaining boreholes.

Rael (1999, pg. 4-3) compared the recorded density data in each borehole to the idealized response in all of the stratigraphic zones where geophysical density data were collected. The recorded density data were then visually compared to the values in each of the four zones in all boreholes, resulting in correction factors. Rael (1999, Table 3) documents the density corrections for each borehole required to bring density data in line with the idealized response.

Rael (1999) also reproduced Nelson's (1996) editing process required to correct for conditions such as rugosity of the borehole, wall roughness, fractures, and lithophysal zones (Rael, 1999, pg. 4-5). Such corrections remove inaccurate measurements or density spikes and result in 
quality inputs. The method used to remove these artifacts involved a hand editing process also used but not documented in Nelson (1996). This process involved several approaches:

1. Removing anomalous data and substituting null or missing values

2. Drawing a straight line between two known valid readings bordering the zone of bad data

3. Interpolating between points within the zone that are judged to be accurate or

4. Using values derived from other log data such as gamma ray, neutron, or resistivity to guide the editing process.

As Rael (1999, pg. 4-7) observed, the data from the older data set was, in most cases, better than the modern data and required less editing. Better borehole conditions existed in earlier borehole logging.

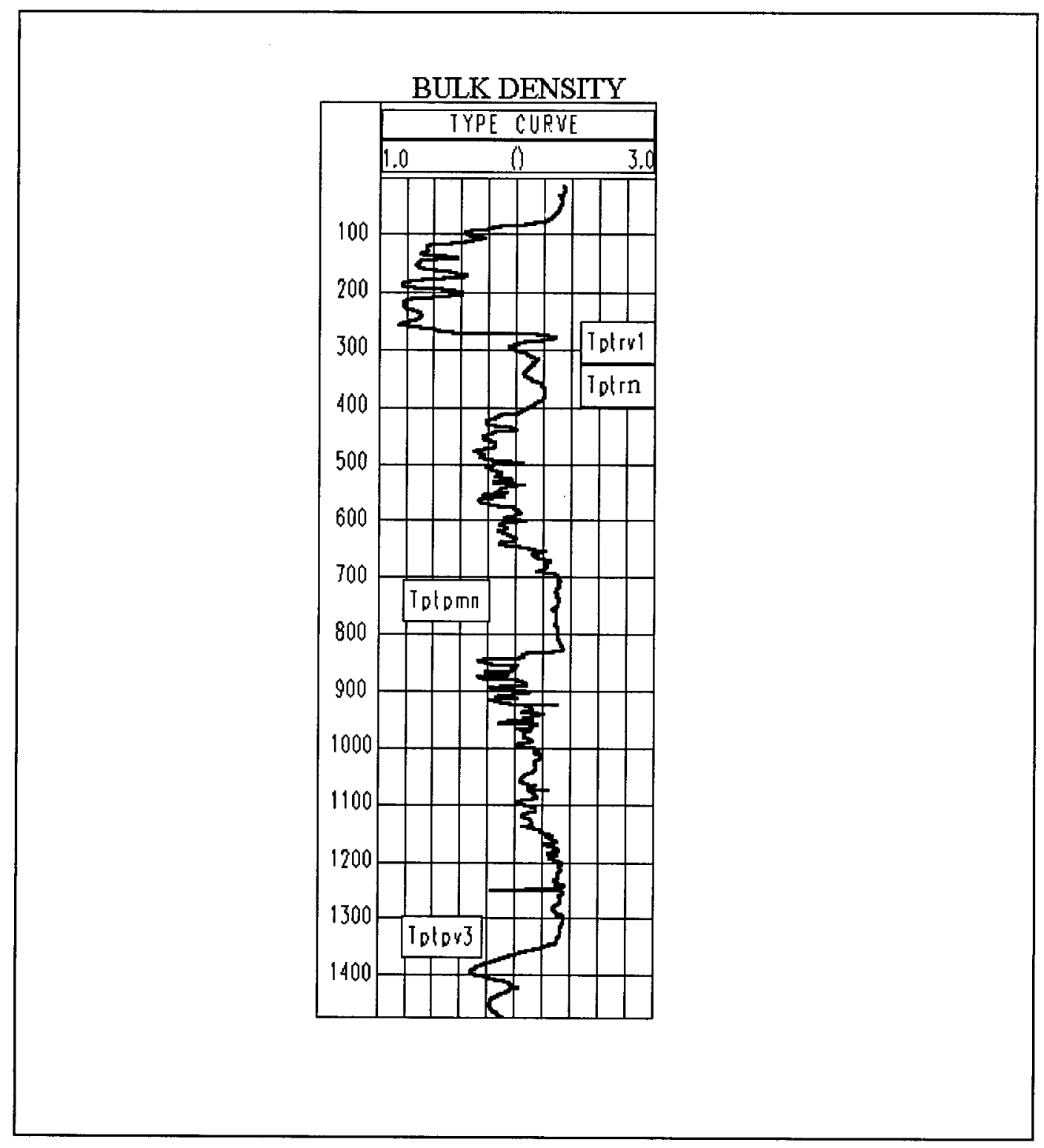

Figure 1. Idealized Response of Bulk Density Data in Tptrv1, Tptrn, Tptpmn, and Tptpv3 


\subsection{MATRIX DENSITY DATA}

Rael (1999, pg. 4-12) cited the following priority for assigning matrix density values (GRNDEN) in porosity calculations:

1. Core data

2. XRD data

3. Existing matrix density data on the data set

4. Correlated matrix density curve averaged from SD-7, SD-9, SD-12, UZ\#14 and UZ\#16.

Table 2 shows the average formation density (e.g. matrix density) values for specified stratigraphic intervals obtained from core data and from mineralogy data. Where possible, Rael (1999) applied core-calculated densities collected at stratigraphic intervals in boreholes with core data to those boreholes that did not have core data. Flint (1998) is the source of the particle densities determined for core. In modern boreholes, porosity computations are preferably calculated using core porosities (CRWMS M\&O, 1996a, b).

Consistent with Nelson's (1996, pg. 21, Table 6) methodology for core-based densities, two separate matrix density values measured at different conditions are used to calculate total and effective porosities. The core analyses provide porosity measurement conditions (1): $60^{\circ} \mathrm{C}$ and 65 percent relative humidity $(\mathrm{RH})$, and (2) $105^{\circ} \mathrm{C}$ oven-dried (OD) cores. "Effective porosity" is calculated using condition (1), the RH density measurement. Effective porosity quantifies only the pore space that could contain fluids that would flow under normal hydraulic conditions. Porosity values from condition (2), the OD measurements, are referred to as "total porosity" since their measurement includes the effective porosity plus the water (porosity) that was chemically or physically bound to the rock.

Rael (1999, pg. 4-12) chose to minimize use of XRD data because the calculation of grain density is indirect and core-derived densities are more defensible. The derivation of total porosity from XRD density data, equivalent to the core OD measurement, adds to this uncertainty. The level of uncertainty is shown in Table 2 as a range of XRD-based matrix density (plus and minus). As evident in Table 2, the XRD data is relied upon mostly in the deeper, older formations where no core data exists. Where XRD was used, Rael $(1999$, pg. 4-10, Table 5) lists the minerals and ranges of densities and the data sources used (Nelson and Anderson 1992, Table 4; Dana 1932; Schlumberger 1988; Carmichael 1989; and Atlas 1985). XRD data from Vaniman (1997 and 1998) is listed by DTN in Rael (1999, Appendix B, pg. B-39).

Rael (1999) also discusses use of a matrix density curve constructed by combining the cored boreholes along with USW G-1 and USW G-2 into one data set then depth-matching all of them to G-1, using the bulk density curve as the medium. This allowed the computation of an average grain density curve using a combination of core data, XRD, and the existing grain data associated with G-1 and G-2. Where required, the average grain density curve (along with the bulk density curve) was compared to each of the other boreholes and shifted by the amount needed to match the two bulk density curves to the values with equivalent zones in the G-1 well. 
Table 2 Formation Density ( $\mathrm{gm} / \mathrm{cc}$ ) Averages from Core and XRD Data

(after Rael 1999 pg. 4-13, Table 6)

\begin{tabular}{|c|c|c|c|c|c|c|c|}
\hline \multirow[t]{2}{*}{ Interval Name } & \multicolumn{3}{|c|}{ CORE } & \multicolumn{4}{|c|}{ XRD } \\
\hline & $\begin{array}{c}\text { RH Matrix } \\
\text { Density }\end{array}$ & $\begin{array}{l}\text { OD Matrix } \\
\text { Density }\end{array}$ & $\begin{array}{c}\text { Number of } \\
\text { Samples }\end{array}$ & $\begin{array}{c}\text { Matrix } \\
\text { Density } \\
\text { (Avg.) }\end{array}$ & $\begin{array}{c}\text { Matrix } \\
\text { Density } \\
(+)\end{array}$ & $\begin{array}{c}\text { Matrix } \\
\text { Density } \\
(-)\end{array}$ & $\begin{array}{c}\text { Number of } \\
\text { Samples }\end{array}$ \\
\hline Tpc_un & 2.49440 & 2.51584 & 734 & 2.501 & 2.508 & 2.492 & 12 \\
\hline Tpcpv3 & - & - & - & 2.380 & 2.372 & 2.391 & 1 \\
\hline Tpcpv2 & 2.29033 & 2.43926 & 66 & 2.360 & 2.354 & 2.375 & 4 \\
\hline Tpcpv1 & 2.23332 & 2.32406 & 65 & 2.284 & 2.293 & 2.272 & 4 \\
\hline Tpbt4 & 2.27121 & 2.41540 & 25 & 2.347 & 2.351 & 2.342 & 2 \\
\hline Tpy & 2.27801 & 2.32854 & 81 & 2.363 & 2.369 & 2.357 & 14 \\
\hline Tpbt3 & 2.30517 & 2.41648 & 54 & 2.304 & 2.313 & 2.291 & 17 \\
\hline Tpp & 2.20578 & 2.26177 & 166 & 2.342 & 2.352 & 2.328 & 21 \\
\hline Tpbt2 & 2.28775 & 2.38011 & 117 & 2.399 & 2.405 & 2.391 & 18 \\
\hline Tptrv3 & 2.30323 & 2.39905 & 43 & 2.383 & 2.400 & 2.357 & 10 \\
\hline Tptrv2 & 2.36244 & 2.40522 & 9 & 2.413 & 2.419 & 2.404 & 3 \\
\hline Tptrv1 & 2.45821 & 2.47179 & 14 & 2.328 & 2.345 & 2.306 & 7 \\
\hline Tptrn & 2.52867 & 2.55096 & 357 & 2.531 & 2.543 & 2.532 & 64 \\
\hline Tptrl & 2.48449 & 2.51795 & 39 & 2.500 & 2.503 & 2.496 & 13 \\
\hline Tptf & - & - & - & 2.473 & 2.488 & 2.432 & 2 \\
\hline Tptpul & 2.47900 & 2.51275 & 373 & 2.500 & 2.509 & 2.487 & 76 \\
\hline Tptpmn & 2.49212 & 2.52724 & 276 & 2.499 & 2.504 & 2.492 & 46 \\
\hline Tptpll & 2.52035 & 2.54877 & 457 & 2.521 & 2.525 & 2.515 & 94 \\
\hline Tptpln & 2.51865 & 2.55426 & 273 & 2.514 & 2.520 & 2.513 & 74 \\
\hline Tptpv3 & 2.37026 & 2.39736 & 106 & 2.293 & 2.298 & 2.523 & 39 \\
\hline Tptpv2 & 2.32404 & 2.35648 & 25 & 2.273 & 2.277 & 2.269 & 18 \\
\hline Tptpv1 & 2.21457 & 2.30745 & 75 & 2.246 & 2.271 & 2.258 & 46 \\
\hline Tpbt1 & 2.23630 & 2.36590 & 10 & 2.266 & 2.277 & 2.248 & 8 \\
\hline Tac & 2.18960 & 2.32797 & 358 & 2.273 & 2.280 & 2.255 & 111 \\
\hline Tacbt & 2.27208 & 2.44075 & 72 & 2.300 & 2.306 & 2.292 & 34 \\
\hline Tcp4v & 2.23980 & 2.40849 & 51 & 2.310 & 2.348 & 2.345 & 19 \\
\hline Tcp3n2c & 2.51359 & 2.57789 & 126 & 2.549 & 2.556 & 2.539 & 24 \\
\hline Tcp3md & 2.52852 & 2.56816 & 114 & 2.549 & 2.551 & 2.545 & 34 \\
\hline Tcp_orange & 2.21312 & 2.36752 & 25 & 2.339 & 2.341 & 2.335 & 20 \\
\hline Tcp13n1c & 2.43658 & 2.50889 & 19 & 2.431 & 2.462 & 2.453 & 7 \\
\hline Tcp13n1v & 2.25381 & 2.41229 & 237 & 2.287 & 2.292 & 2.279 & 49 \\
\hline Tcpbt & 2.29000 & 2.44129 & 7 & 2.387 & 2.432 & 2.409 & 13 \\
\hline Tcbn2v & 2.39978 & 2.46989 & 9 & 2.409 & 2.416 & 2.400 & 7 \\
\hline Tcbn2c & - & - & - & 2.419 & 2.427 & 2.416 & 7 \\
\hline Tcb_green & - & - & - & 2.610 & 2.613 & 2.607 & 8 \\
\hline Tcbmd & 2.55021 & 2.57297 & 97 & 2.566 & 2.592 & 2.575 & 35 \\
\hline Tcbntv & - & - & - & 2.399 & 2.410 & 2.383 & 2 \\
\hline Tab_lower & 2.28866 & 2.37534 & 29 & 2.347 & 2.392 & 2.362 & 15 \\
\hline Tcbbt & 2.34400 & 2.41150 & 6 & 2.385 & 2.390 & 2.373 & 8 \\
\hline Tctn2v & 2.34640 & 2.43680 & 5 & 2.416 & 2.421 & 2.409 & 9 \\
\hline Tctn2c & 2.33990 & 2.43024 & 21 & 2.475 & 2.482 & 2.473 & 12 \\
\hline Tctmd & - & - & - & 2.607 & 2.609 & 2.603 & 1 \\
\hline Tct_blue & - & - & - & 2.568 & 2.604 & 2.602 & 17 \\
\hline Tctn1c & - & $\therefore$ & - & 2.598 & 2.600 & 2.594 & 9 \\
\hline Tctn1v & - & - & - & 2.522 & 2.532 & 2.508 & 1 \\
\hline Tct_lower & - & - & - & 2.513 & 2.518 & 2.499 & 19 \\
\hline Tctbt & - & - & - & 2.482 & 2.494 & 2.457 & 5 \\
\hline OldTert & - & - & - & 2.554 & 2.552 & 2.557 & 1 \\
\hline
\end{tabular}


Rael (1999, Appendix B, Pg. B-38) shows DTNs and accession numbers for the core densities measured in modern boreholes. None of the 24 historical boreholes had core measurements, consequently core density data from the geologic intervals identified in Table 2 are inferred from modern boreholes to similar intervals in historical boreholes. As shown in Table 2, porosity computations are reliant on the more accurate core data for significant unsaturated zone and upper saturated zone geologic intervals, including:

- The upper volcanic aquifer of the paintbrush group (e.g. Tpcpv2 and Tptrv2; Tiva Canyon non-partly-welded vitric zones and Topopah Spring upper non-part-welded zones)

- Flow paths occurring in the Prow Pass (Tcp) and BullFrog (Tcb) members

For deeper intervals in the saturated zone, matrix densities are based on the alternative density inputs based on data availability. Rael (1999, Appendix G) shows the programming used to implement this prioritization for each borehole. DTN MO9910POROCALC.000 shows the matrix density values used for each borehole as follows:

- Particle(s) Density - for RH values used in effective porosity computations

- Particle Density - for OD values used in total porosity computations

Input densities used in the porosity calculation are shown as linear plots with depth along side the porosity output in each on the borehole cross-sections from Rael (1999) and in DTN MO9910POROCALC.000. In both cases, the density inputs can be compared with core and XRD densities presented in Table 2.

\subsection{NEUTRON DATA AND VOLUMETRIC WATER CONTENT}

The volumetric water content (VWC), or water-filled porosity, is a required input to calculate porosity in saturated zones in the porosity-density equation (3). Neutron data are required to determine the amount of water contained in the rocks. Specifically, since neutron porosity data are required, Rael (1999) used the outputs from Nelson (1996) since that work provided the neutron response calibrated in porosity. These parameters are shown in Appendix A sample data input sheets, including PHINBC, the thermal neutron porosity curve (NBC) corrected for borehole size, and PHIWENP, the composite epithermal neutron porosity data.

Neutron devices must be calibrated to the specific lithology of the formation in order to provide accurate information. The types of neutron tools used in the various boreholes are discussed in Rael (1999). Historically, most of the neutron data in the historical boreholes had to be converted to porosity using a calibration method developed and used by Nelson (1996, pg. 9-14). Principally older neutron porosity data were recorded on sandstone porosity scales. Modern neutron data, acquired with tools providing response calibrated in porosity, required no calibration. Modern data were mostly recorded on a limestone matrix scale. In both cases, Nelson (1996) had to convert modern and historical data to a porosity scale consistent with the lithology of the YMP volcanics. The reader is referred to Rael (1999, pg. 4-12) and the NUEPOR software documentation (STN: 10488-0-00) for further explanation of these details as well as the selection of neutron data incorporated as input at different depth intervals. 
Rael (1999, pg. 5-2) used the composite neutron curves from Nelson (1996) to determine the volumetric water content parameter by limiting the neutron porosity to the density-based porosity computed with fluid porosity $\mathrm{kf}=1.00 \mathrm{gm} / \mathrm{cc}$ below the Tptpv1. The neutron porosity above the Tptpv1 was limited by the density-based porosity computed with $\mathrm{kf}=0.001223 \mathrm{gm} / \mathrm{cc}$, the density of air. The assumption is that there is little bound water in the Topopah Spring but bound water exists below Tptpv1.

Rael (1999, Section 4.4) compared the epithermal neutron porosity used by Nelson (1996) and neutron porosities gathered with the modern data set in boreholes USW G-2, USW WT-2, USW WT-10, and UE-25 WT\#12 where both historical and modern neutron data were collected. The comparison yielded a linear trend and supports the accuracy of the historical data. Two forensic evaluations of older boreholes for UE-25 $\mathrm{p} \# 1$ and USW H-6 being completed outside of this qualification also support the neutron data (Appendix B). Note that the software NUE_POR Version 0 (STN: 10488-0-00) reproduces the techniques used by Nelson (1996) to parameterize the neutron data for a given borehole.

\subsection{FORENSIC ANALYSES: UE-25 p\#1 AND USW H-6}

As discussed in Section 2.1.1, the Data Qualification Team reviewed forensic evaluations prepared for the two selected historical boreholes and found the reports to be technically complete and appropriate for reference as part of this qualification report (Olsen and Rael 2001; Rael 2001). The Data Qualification Team has summarized and incorporated relevant portions of the reports in Appendix B.

The forensic evaluations are independent of the original USGS documentation as well as the recalculation of porosity and porosity-related output by Rael (1999). The two reports by Olsen and Rael (2001) and Rael (2001) support this qualification activity by duplicating the compositing process and computational methods used by Nelson (1996) to develop the historical neutron data, later adopted as the basis for Rael's (1999) porosity calculations.

Dresser-Atlas and Birdwell logging companies acquired the majority of historical geophysical data in the 1980's, including natural gamma ray, resistivity, caliper, density, compensated neutron, epithermal neutron and sonic data and many other types of logs using various geophysical tools. Dresser-Atlas and Birdwell also acquired historical geophysical logging data for UE-25 p\#1 and USW H-6. The forensic evaluations document industry standard methods were employed for a wide range of geophysical measurements with adequate levels of accuracy. These evaluations provide confidence in data acquisition in other historical boreholes used in the porosity calculations.

Excerpts from the two preliminary forensic reports (Olsen and Rael 2001: Rael 2001) summarized in Appendix B include figures that demonstrate that independently-acquired measurements expected to respond similarly to rock porosity showed comparable measured response. The forensic evaluations include comparisons of unqualified neutron data and qualified geophysical data discussed in Section 1.2. Technical observations based on the Data Qualification Team review are summarized as follows: 


\section{Borehole USW H-6}

- Appendix B, Figure B1 shows expected correlation between bulk density, neutron, gamma ray data and induction resistivity data measured in borehole H-6. Additional comparisons using boreholes USW H-6, USW H-5 and USW SD-6 also support the accuracy of the Dresser-Atlas and Birdwell logging measurements in historical boreholes.

- Specifically, Olsen and Rael (2001) observed the correlation between the thermal (CNP) and epithermal neutron (ENP) data with respect to density data and concludes both sets of data are responding similarly to the porosity of the rock and are within expected ranges. In addition, Olsen and Rael (2001) shows repeatability in main passes of the compensated borehole density tool.

- Appendix B, Figure B2 shows a one-to-one correspondence between PHINBC, the thermal neutron porosity curve (NBC) corrected for borehole holesize, and basic neutron data (PHICNP) partly reconstructed from Nelson (1996). The reproducibility and linear correlation substantiate Nelson's (1996) composite neutron parameter used by Rael (1999) in the porosity calculations.

- Appendix B, Figure B3 shows a one-to-one correspondence between a reconstruction of Nelson's epithermal neutron porosity (PHIWENP) versus the Nelson (1996) raw epithermal data (ENP, represented as $1 \mathrm{Hx} 23 \mathrm{~h} 2 \mathrm{o}$ in Figure B3). This substantiates Nelson's (1996) composite neutron parameter used by Rael (1999) in the porosity calculations.

\section{Borehole UE-25 p\#1}

- Rael (2001) shows the expected correlation between the dual induction resistivity data from UE-25 $\mathrm{p} \# 1$ to several other types of related data measured in the borehole, including bulk density, thermal neutron, and gamma ray data. In addition, Rael (2001) demonstrates repeatability and accepted tolerances among many types of measurements in the main passes in the borehole. In general, these measures of accuracy suggest historical data are of adequate quality.

- Neutron porosity, acoustic data, and bulk density data plotted in Rael (2001) show visual agreement among these sets of data which are all responding to the porosity of the rock (Rael 2001).

- Appendix B, Figure B4 shows a one-to-one correspondence between the reproduced parameter PHICNP, the basic neutron porosity data, and PHINBC, the thermal neutron porosity curve (NBC) corrected for borehole holesize applied to the porosity transform and used by Rael (1999) in porosity calculations. The reproducibility and linear correlation validate Nelson's (1996) composite neutron parameter used by Rael (1999) in the porosity calculations. 
- Appendix B, Figure B5 show a one-to-one correspondence between a reconstruction of Nelson's epithermal neutron porosity (PHIWENP) versus the Nelson (1996) raw epithermal data (ENP) computed in air (shielded). This selected figure substantiates the algorithms used by Nelson (1996) and the composite neutron parameter used by Rael (1999) in the porosity calculations.

- Appendix B, Figure B-6 provides an example of the reproducibility Nelson's final epithermal neutron porosity data (PHIWENP) used in the porosity calculations. Plotted against a reconstruction from the raw data (computed PHIWENP) with the appropriate shielded water transform applied, the two composite logs are shown to correspond adequately to each other over all ranges. Therefore, the algorithms used to produce both are the same and reproducible.

Reproduction of Nelson's (1996) methodology is also supported by the software NUE_POR Version 0 (STN: 10488-0-00) used in the forensic evaluations.

\subsection{CORROBORATION OF CORE POROSITY WITH TOTAL POROSITY DATA}

This section presents the following corroborative approaches to qualifying the porosity calculations and the primary associated developed inputs contained in DTN MO9910POROCALC.000:

- Visual corroboration of the modern data set based on a comparison of core porosities and geophysical-based porosities evident from plots of five modern boreholes.

- Comparison of all computed geophysical-based total porosities and core porosities for each stratigraphic interval that includes modern and historical logs.

- Comparison of modern and historical geophysical porosity results for four boreholes (USW G-2, USW WT-2, USW WT-10, UE-25 WT \#12) generated by historical and modern inputs available for these wells. This comparison augments the technical assessment involving the forensic analyses of USW H-6 and UE-25 p\#1 and further substantiates the adequacy of all primary historical geophysical inputs and porosity calculations.

- Assessment of the geologic continuity of stratigraphic sequences from borehole to borehole inferred from porosity logs and stratigraphic intervals shown in cross-sections in Rael (1999).

\subsubsection{Corroboration of the Modern Borehole Data}

Rael (1999), produced five plots of total porosity curves for modern boreholes: USW SD-7, USW SD-12, USW-SD-9, UE-25 UZ\#16 and USW NRG-7A. These figures are included in this report as the following Figures 2 through 6 and are discussed for corroborative purposes. 


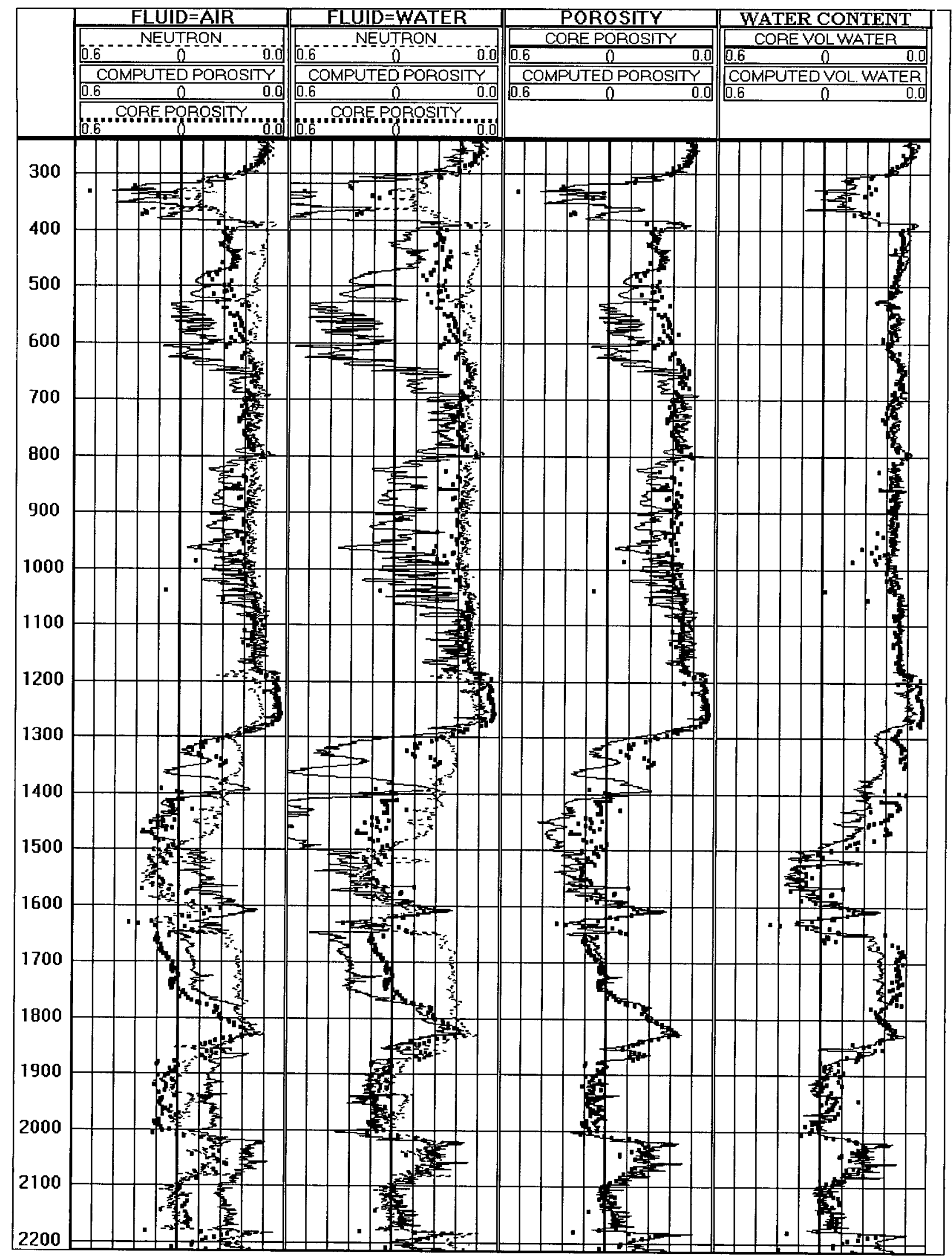

Figure 2. Computed Total Porosity and Core Data USW SD-7 (after Rael, 1999) 


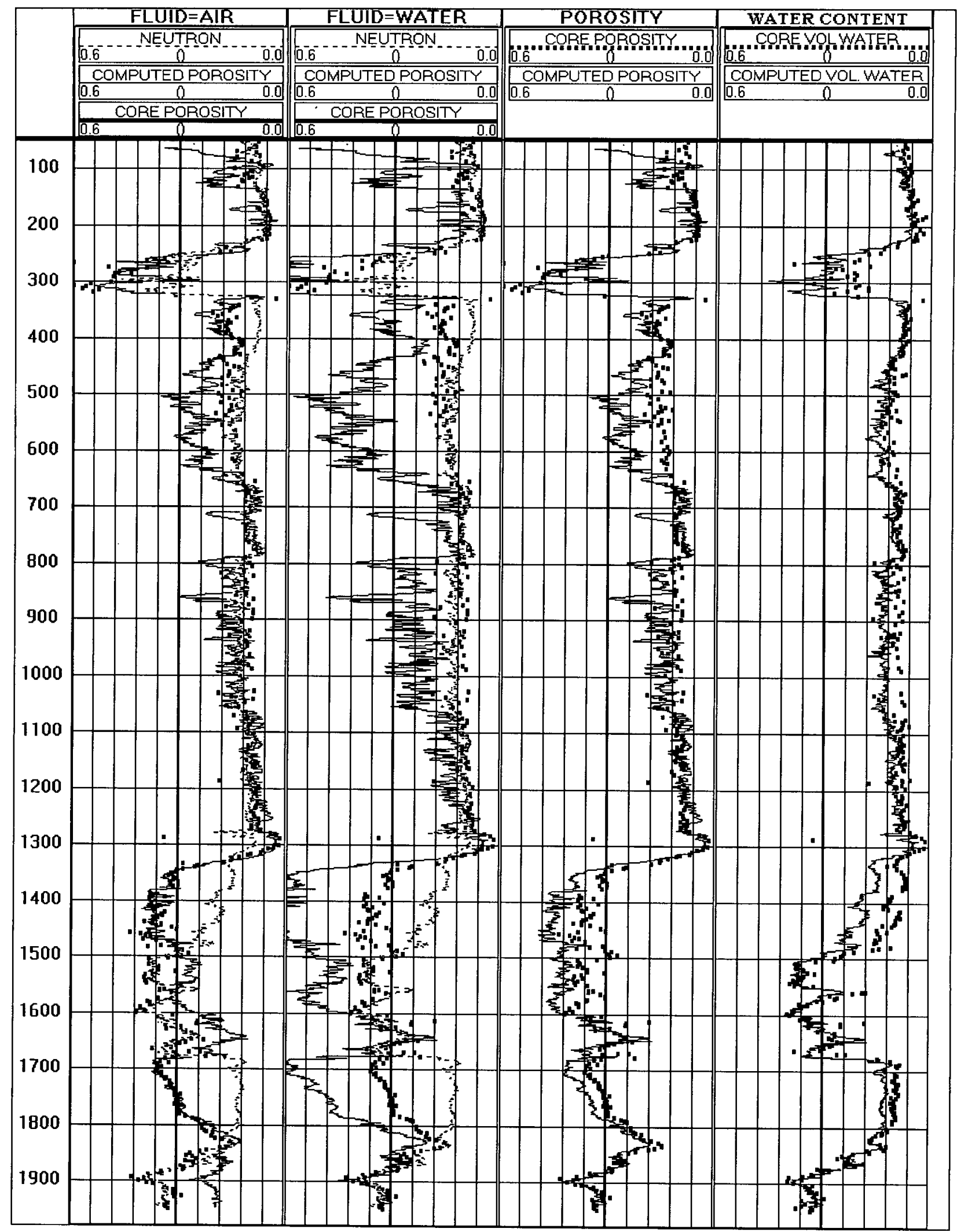

Figure 3. Computed Total Porosity and Core Data USW SD-12 (after Rael, 1999) 


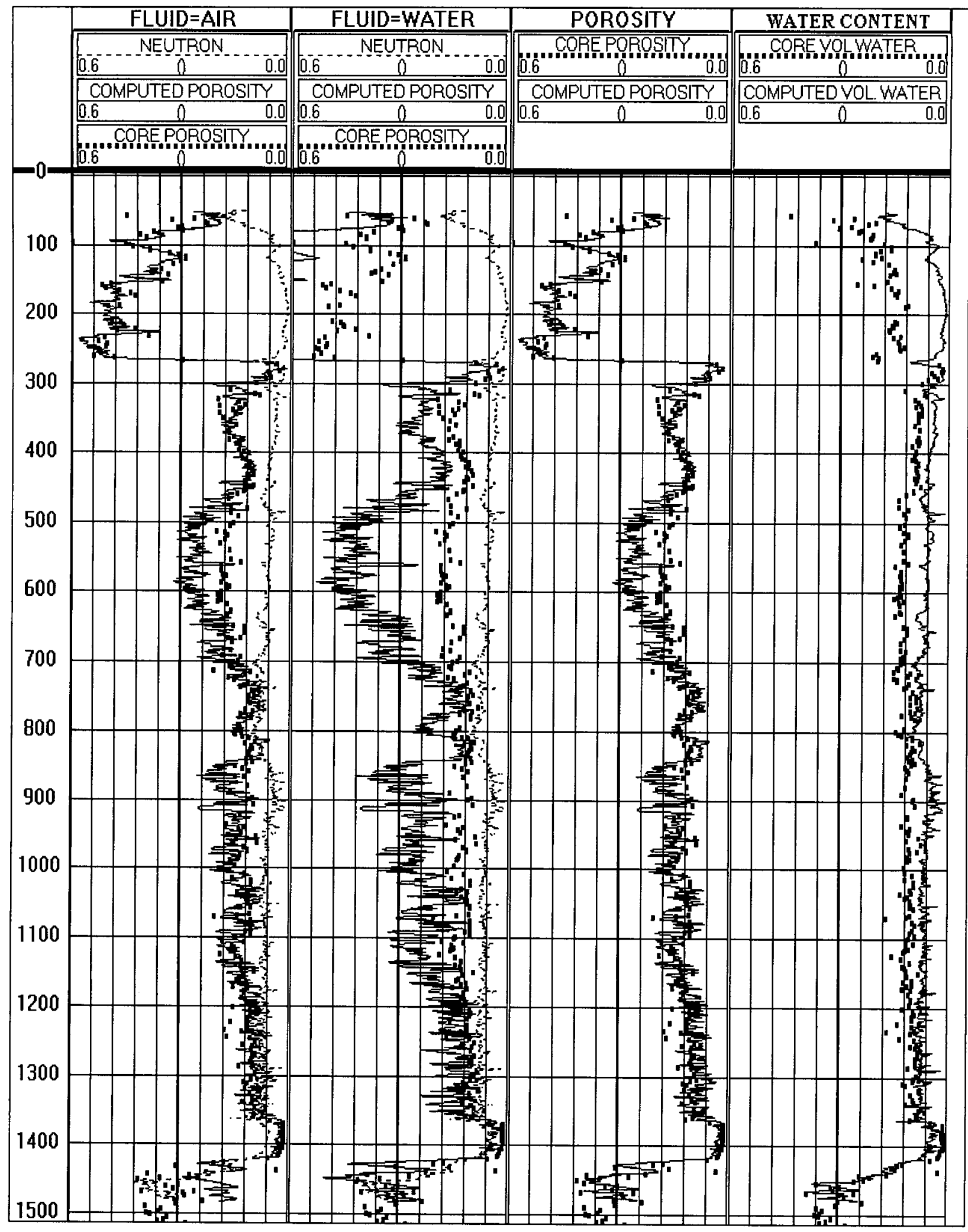

Figure 4. Computed Total Porosity and Core Data USW SD-9 (after Rael, 1999) 


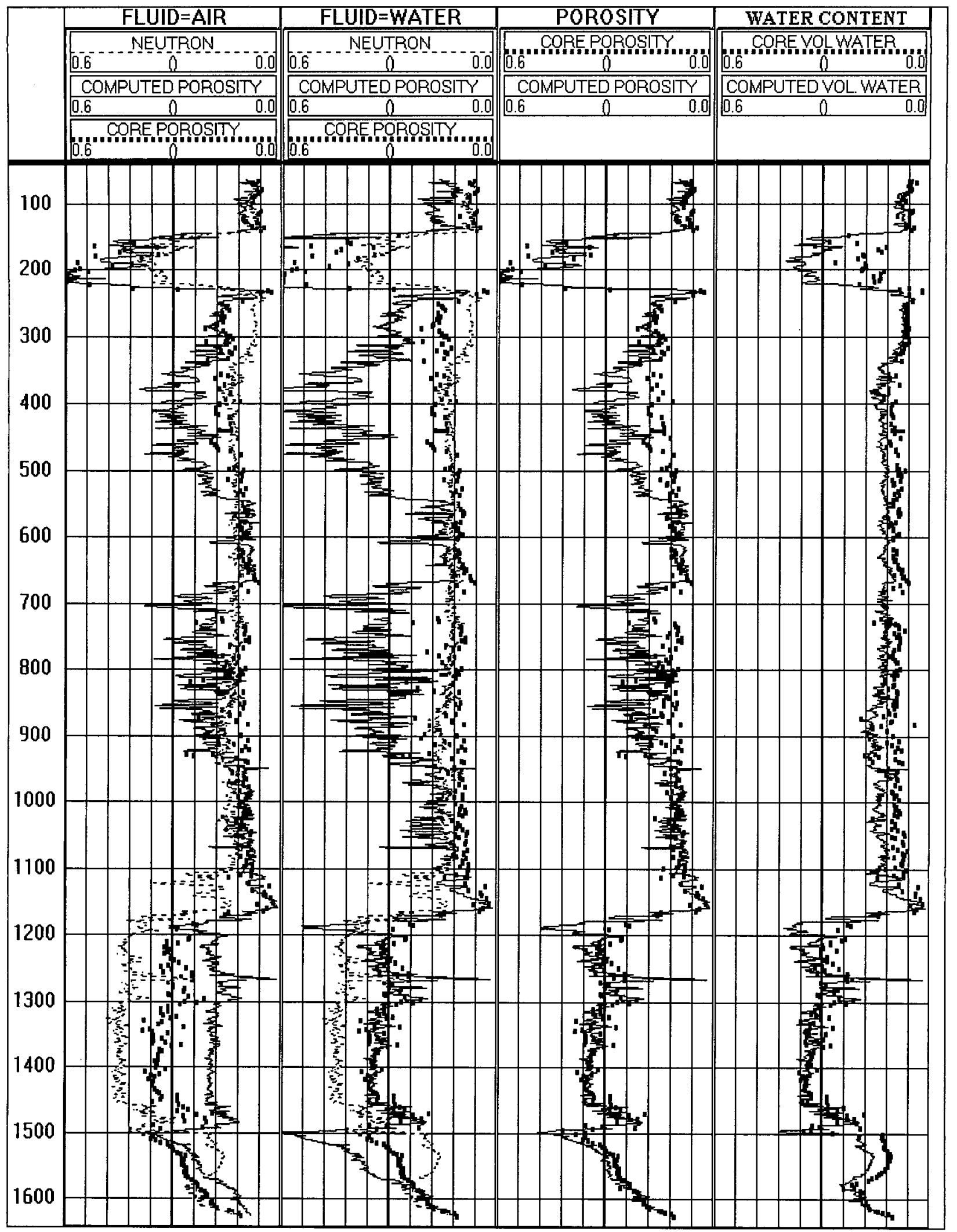

Figure 5. Computed Total Porosity and Core Data UE-25 UZ\#16 (after Rael, 1999) 


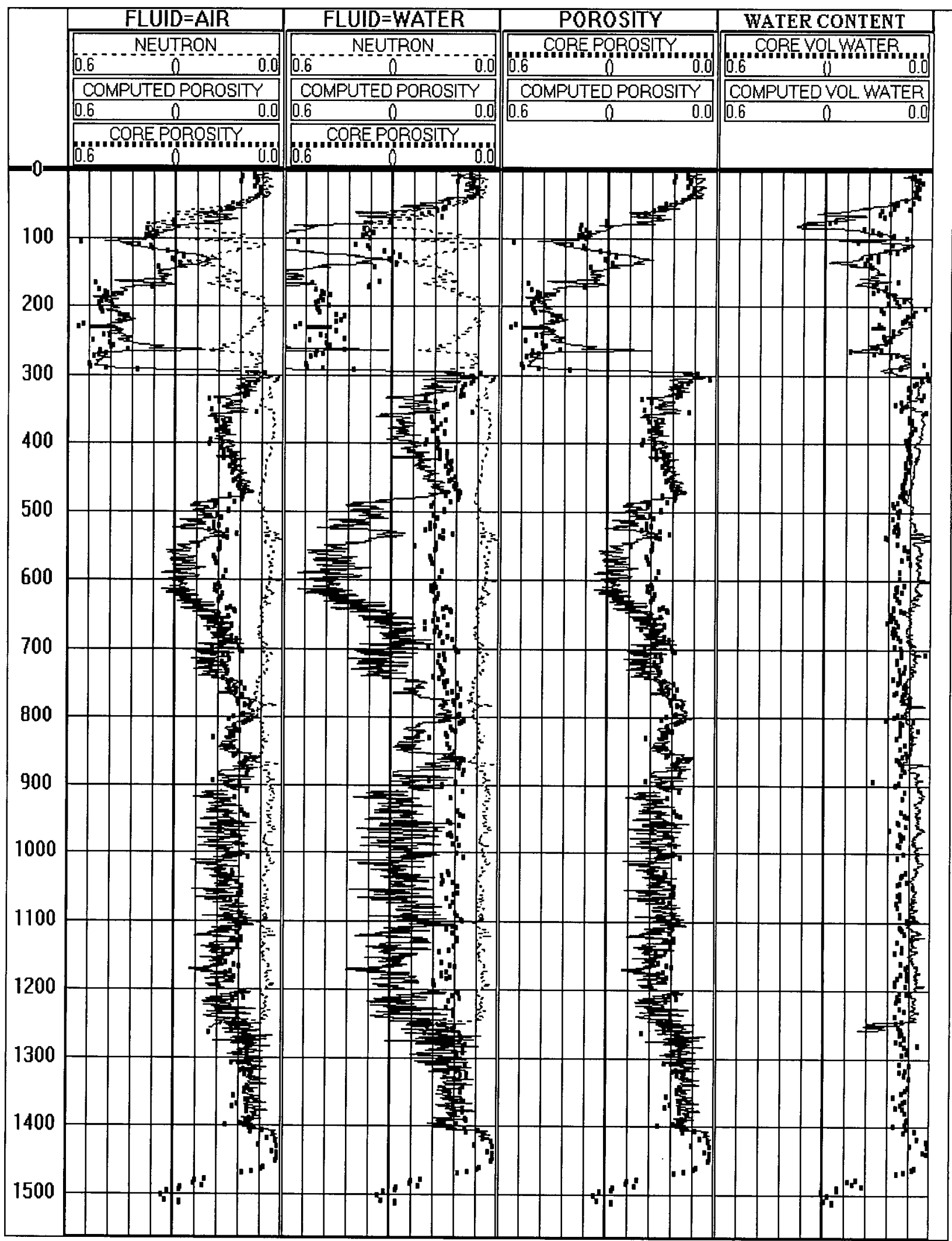

Figure 6. Computed Total Porosity and Core Data USW NRG 7A (after Rael, 1999) 
In the first three columns of Figures 2 through 6 , calculated total porosity is compared to core porosity data. In the last column, VWC is the computed volumetric water content obtained from neutron-density data compared to equivalent water-filled porosity measurements on core.

Presented as technical justification for using the porosity determination method, the first column in all the figures shows porosity curves computed from density data using Equation (2) with fluid denisty $(\kappa f)=0.001223$ (FLUID = AIR). Relative to column 2 where FLUID = WATER, Rael (1999) concludes that oven-dried core porosities in column 1 compare more favorably to the computed total porosity in the shallow unsaturated zones. The third column shows porosity curves using Equation (3) for the saturated zone (POROSITY). The computed porosity in the deeper saturated zones compare more favorably with the oven-dried core in Column 3 using Equation (3). This comparison is used to demonstrate the use of separate equations to compute total porosity in the unsaturated and saturated zones (see Section 1.3, this report).

Figures 2 through 6 also demonstrate general visual corroboration of the log-calculated total porosity and volumetric water content data with that from equivalent core data. In column \#1 (FLUID=AIR), log-calculated and cored-based total porosities visually coincide in the shallowest low and high porosity zones evident in the series of figures. Below these zones, the results are variable; however, the two data sets show the same overall trend with log-calculated porosities having slightly larger porosities. In deeper portions of the borehole in column 3 (POROSITY), the two data sets are visually coincident in all boreholes. In the last column (WATER CONTENT), computed volumetric water content obtained from neutron-density data compares favorably to core-measured water volume in all boreholes.

Figure 7 presents a comparison of total porosity data measured from laboratory core data with total porosity calculations derived using modern and historical geophysical logs as input. The comparison utlilizes the same stratigraphic intervals as those presented in Rael (1999; Appendix A) "Intervals used for Core Averaging and Parameter Selection". Geophysical log porosity calculations at 0.5 foot intervals are averaged over the thickness of each stratigraphic interval. The number of log samples represent the total population of porosity measurements available within the specific stratigraphic interval from all modern and historical boreholes (number at right in parentheses next to interval in Figure 7). Core porosity is similarly averaged over each stratigraphic interval with the number of samples available (number at left in parenthese next to interval in Figure 7). The data used to create Figure 7 are contained in Appendix A, Table A8.

The cross-plot of the data shows a linear trend correlating core porosity data with total porosity derived using modern and historical geophysical data sets. Outliers are expected due to the representativeness of the core sample volume relative to the volume of stratigraphic intervals sampled. Samples measuring lithophysal zones and the number of samples are also factors (Figure 7). Geophysical-based porosities were developed to better represent this physical property with depth in the borehole. In any case, the linear trend tends to substantiate the validity of Rael's (1999) porosity calculations. More importantly, the core porosity data substantiate porosity results that include both modern and historical borehole data sets. 


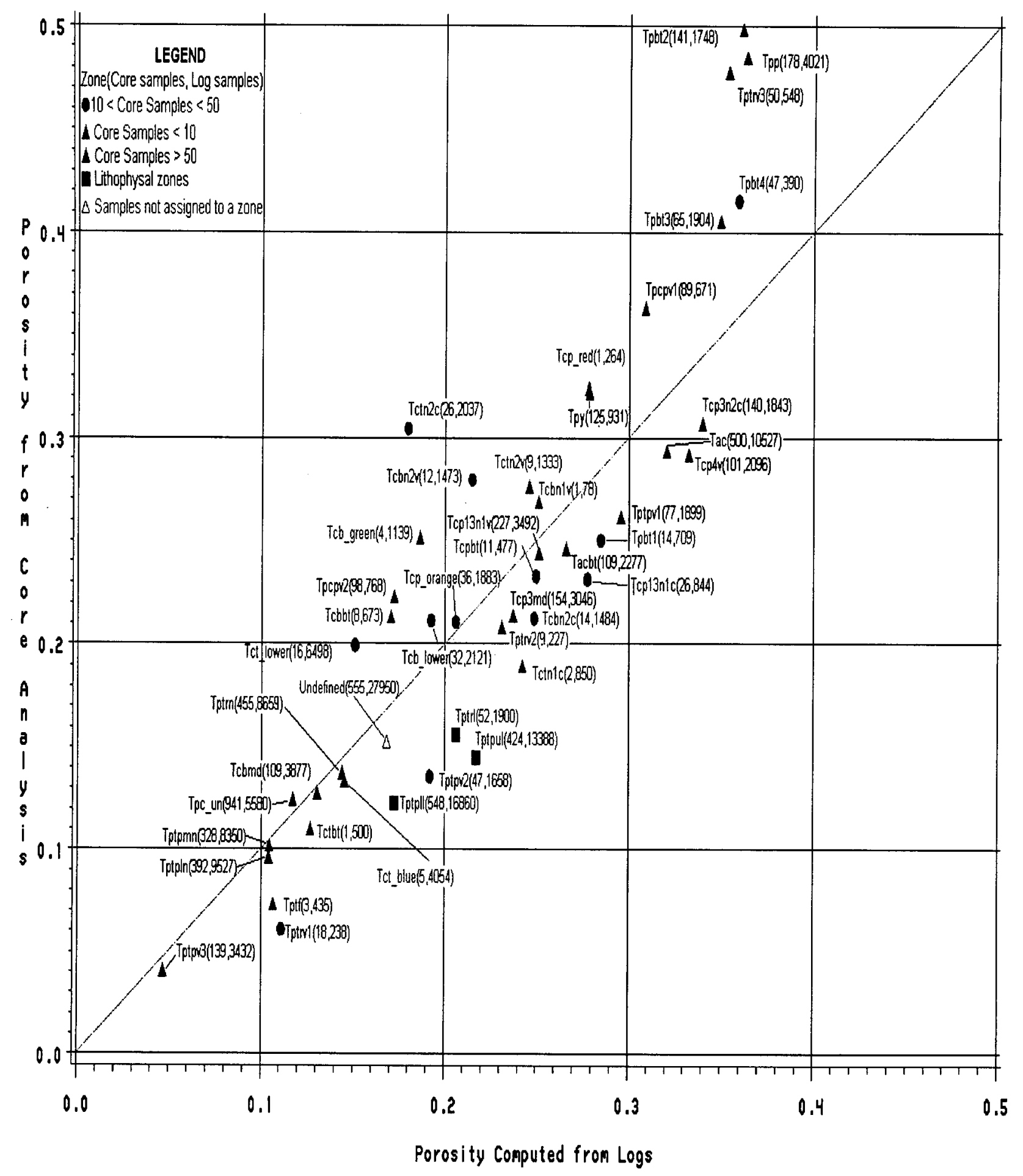

Figure 7. Cross-Plot of Core Porosity and Porosity Computed from Logs (see Appendix A, Table A8 for source DTNs and Table 2 for a key to formations).

While Figures 2 through 6 corroborate only the modern borehole data set, it is important to emphasize that core porosity calculations for historical boreholes relied on the same equations, 
methods and input as applied to modern boreholes. Consequently, the corroboration of the modern boreholes by Rael (1999) and the linear trend established in Figure 7 provides confidence in the porosities computed for the historical boreholes.

\subsubsection{Corroboration of Historical Input Data with Modern Input Data}

Four historical boreholes logged in the early 1980's were re-logged in the mid 1990's using modern procedures under the QARD, as discussed in Section 1.2 and shown in Table 1. These boreholes include:

- USW G-2

- USW WT-10

- UE-25 WT\#12

- USW WT-2

The availability of the modern and historical borehole data sets allowed a comparison of the calculated porosities as additional corroboration of the historical data set. The Data Qualification Team used the same input parameters and produced effective porosities and total porosities calculated with modern and historical geophysical data sets. Variability in the porosity results between the two porosity results would be caused primarily by changes in the modern and historical geophysical input data: neutron and bulk density. As discussed in Section 3.2, developed matrix density inputs are not available for historical boreholes. The GRNDEN values, as well as other inputs to the porosity calculations, are the same for each of the borehole data sets compared.

Figures 8 through 11 show the porosity results calculated using the modern and historical data sets: total porosity and effective porosity. The historical and modern density and neutron input data are also shown for comparison. The caliper data in Figure 8 through 12 are included to assess whether hole conditions might be affecting either the input or the output. Rugosity, a condition where the hole size and geometry change with depth as a result of washout and/or collapse of the borehole walls, can lead to expected differences in input data and output results. As noted in Section 3.1, historical bulk density in an older hole may be considered as accurate or more accurate than modern data collected in the same hole due to the editing process required to correct for degradation of the borehole. The accuracy of neutron measurements is also affected by the rugosity of the borehole.

Figure 8 shows the results of the comparison involving density and neutron data collected at three different times within USW G-2: 1981, 1991 and 1995. The total and effective porosities generally show the same general pattern among all data sets. There are differences in the magnitude of the porosity, particularly between 900 and 1200 feet in depth. In this case, the 1981 data appear to better correlate with the 1995 modern data in this zone even though the vendors and equipment differed from the vendors and equipment involved in the acquisition of the 1991 and 1995 data sets. 


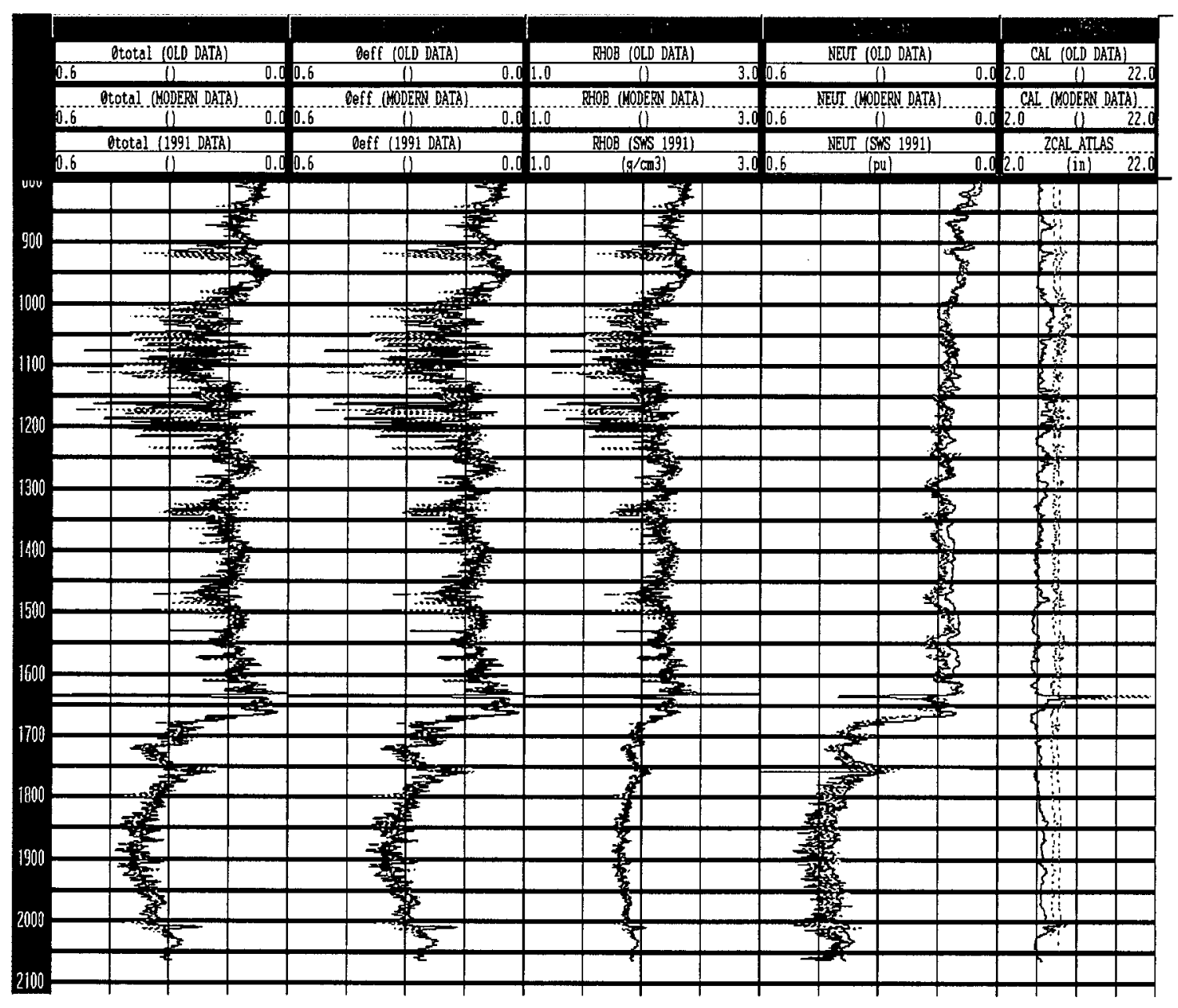

Figure 8. Comparison of Porosity Results Using Old and Modern Data Sets for USW G-2.

Appendix $\mathrm{C}$, Figures $\mathrm{C} 1$ and $\mathrm{C} 2$ plot the effective porosity and total porosity, respectively, derived from the Figure 8 data sets for 1981 and 1995. The discussions refer to porosity units (pu), a measure of porosity defined as the ratio of the volume of voids to volume of the rock sample. Figure $\mathrm{C} 1$ demonstrates a linear trend between the effective porosity results calculated with modern and old data sets at higher porosities. The trend is less linear at lower porosities. The reason may be due to differences in the neutron input data. Both show the same character but differ in magnitude between the two data acquisition periods. Newer neutron data were collected with a very accurate instrument, the Sidewall Neutron Porosity (SNP) tool. The tool does not require calibration to porosity, it accounts for rugosity and provides excellent data in both air-filled and water-filled intervals (Rael, 1999).

Figure 9 shows a similar comparison for USW WT-10 between two existing data sets representing inputs from one modern and one older borehole logging event. The comparison shows a visual corroboration despite the large difference between the neutron data at $650 \mathrm{ft}$. The comparison is not as good at the shallower level due to hole conditions as evidenced by the caliper log. Overall, Appendix C, Figures $\mathrm{C} 3$ and $\mathrm{C} 4$ demonstrate a better linear trend along the best fit line for the two porosity comparison than USW G-2. 


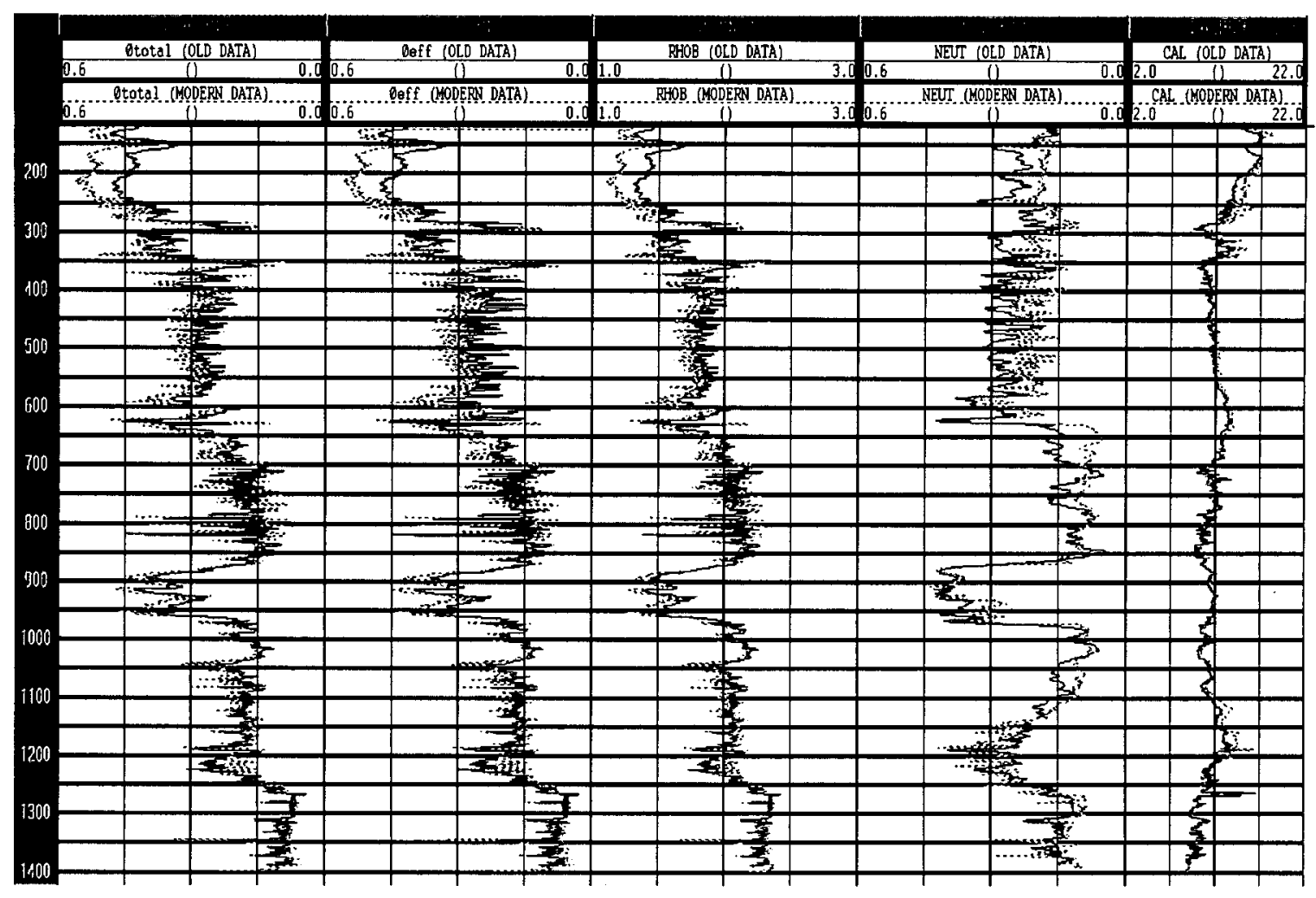

Figure 9. Comparison of Porosity Results Using Old and Modern Data Sets for USWWT-10.

Figure 10 shows a comparison of the porosity results from the modern and older data sets for UE-25 WT\#12. The output and input data curves display very similar character and values. The comparison between the neutron data is good overall but the density data from the modern data set appears to be adversely affected by hole conditions. Appendix C, Figures C5 and C6, shows a linear trend below $0.15 \mathrm{pu}$ but becomes more incoherent as the porosity increases. In this case, at higher porosities the scatter suggests that modern hole conditions are affecting the comparison. 


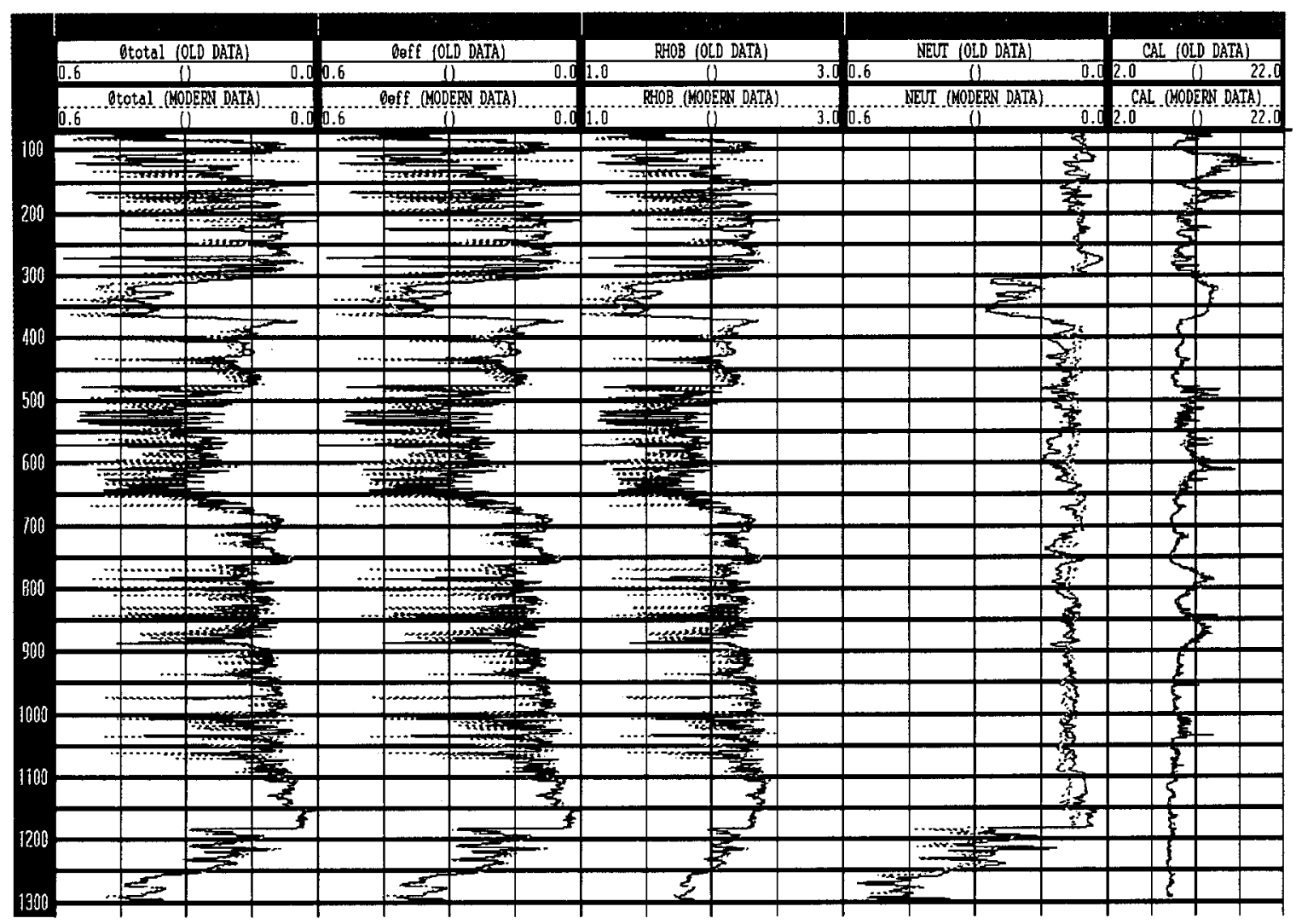

Figure 10. Comparison of Porosity Results Using Old and Modern Data Sets for UE-25 WT\#12.

Figure 11 shows a comparison of the porosity results from the modern and older data sets for USW WT-2. The comparison of the porosity data output are good in those zones that are not affected by borehole rugosity. Appendix C, Figures C7 and C8 show this comparison as an acceptable linear trend.

Appendix $\mathrm{C}$ shows two results, two cases where a linear trend is established and two cases where the comparison is more scattered. Overall, the pattern of porosity results between the old and modern data sets are duplicated in Figures 8 through 11. In three out of four cases, the effect of borehole rugosity on the modern data measurements cannot be precluded as influencing the accuracy of the measurements and localized differences in the magnitude of the input and/or porosity output. This analysis suggests there is inherent variability in all modern and historical geophysical measurements, variability not only related to data collection under a qualified program, but also influenced by the tools used and/or the modern borehole condition. Consequently, while not used in the porosity calculations by Rael (1999), these historical measurements provide additional confidence in the accuracy of the geophysical data acquisition in other older boreholes and the resulting porosity calculations. 


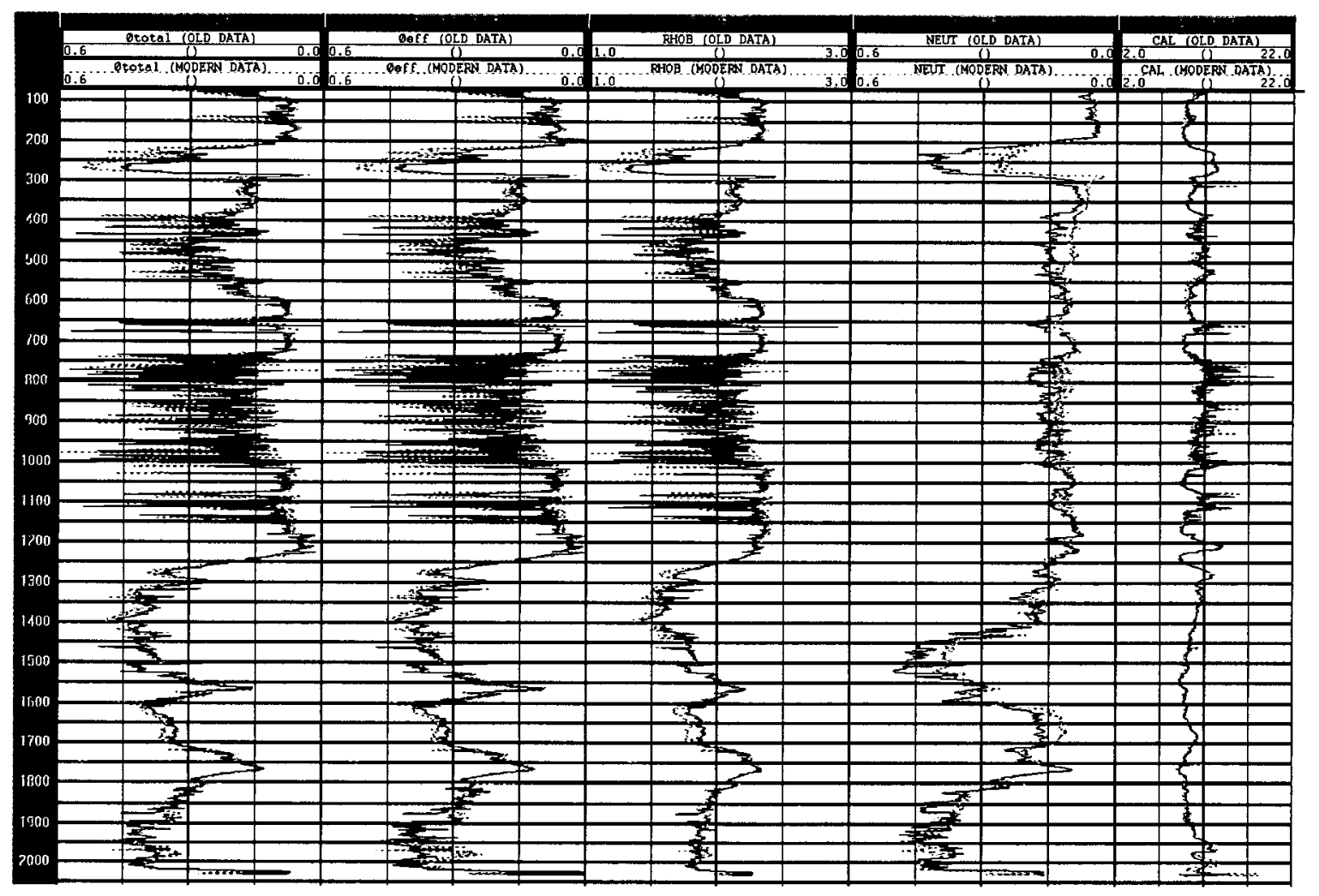

Figure 11. Comparison of Porosity Results Using Old and Modern Data Sets for USWWT-2.

\subsubsection{Porosity Log Technical Assessment and Corroboration}

Variations in porosity with depth are diagnostic of stratigraphic sequences penetrated by the borehole. When more than one borehole penetrates a laterally continuous series of layered rocks, the horizontal correlation of the elevations of these diagnostic features can be used to interpret whether the geophysical output is corroborated by the regional geology and expected continuity of the lithostratigraphy from borehole to borehole.

The 11 geophysical borehole log cross-sections from Rael (1999) are plotted using the depthtabulated porosity data by borehole contained in DTN MO9910POROCALC.000. The plates included in Rael (1999) are too large to include in the qualification report. The borehole logs are equally-spaced and placed side-by-side as cross-sections. Table 3 shows the borehole logs compiled onto each cross-section on each Plate A through K included in Rael (1999). For reference, Figure 12 shows the cross-sections discussed in this section and the location of the boreholes. Thickened black lines represent cross-section plates G, I, J and K from Rael (1999). 
Table 3. Borehole Logs Included in Cross-Section Plates A-K from Rael (1999)

\begin{tabular}{|c|c|c|c|c|c|c|c|c|c|c|c|c|}
\hline Boreholes & $\begin{array}{c}\text { To be } \\
\text { Qualified }\end{array}$ & $\bar{A}$ & B & $\bar{C}$ & $\mathbf{D}$ & $\bar{E}$ & $\bar{F}$ & $\mathbf{G}$ & $\mathrm{H}$ & $T$ & $\mathbf{J}$ & $\bar{K}$ \\
\hline USW G-1 & Historical & & $x$ & & & & & & & & & \\
\hline USW G-2 & Historical & & & $\bar{x}$ & & & & & & & & \\
\hline $\begin{array}{l}\text { USW G- } \\
\text { 3/USW GU-3 }\end{array}$ & Historical & & & & & & & $\mathrm{x}$ & $\mathrm{X}$ & & & \\
\hline USW G-4 & Historical & & & & & $\bar{x}$ & & & & $\bar{x}$ & & \\
\hline USW $\mathrm{H}-1$ & Historical & & $\bar{x}$ & & & & & & & & & \\
\hline USW H-3 & Historical & & & & & & & $\mathrm{X}$ & & & $x$ & \\
\hline USW H-4 & Historical & & & & & & & & & $\bar{x}$ & $x$ & \\
\hline USW H-5 & Historical & & & & $\mathrm{X}$ & & $\bar{x}$ & $\bar{x}$ & & & & \\
\hline USW H-6 & Historical & & & & $\bar{x}$ & & & & & & & \\
\hline UE-25 NRG\#4 & Historical & & & & & $\bar{x}$ & & & & & & \\
\hline UE-25 NRG\#5 & Historical & & & & & $\bar{x}$ & & & & & & \\
\hline USW NRG-6 & Modern & & & & & $x$ & & & & & & \\
\hline USW NRG-7A & Modern & & & & $\bar{x}$ & & & & & & & \\
\hline UE-25 ONC\#1 & Modern & & & & & & & & & $\bar{x}$ & & \\
\hline UE-25 P\#1 & Historical & & & & & & & & $x$ & $\mathrm{x}$ & & \\
\hline USW SD-6 & Modern & & & & & & & & & & & \\
\hline USW SD-7 & Modern & & & & & & & & & & $\bar{x}$ & \\
\hline USW SD-9 & Modern & & & & $\bar{x}$ & & & & & $\bar{x}$ & & \\
\hline USW SD-12 & Modern & & & & & $\bar{x}$ & $\bar{x}$ & & & & & \\
\hline USW UZ-1 & Historical & & $\bar{x}$ & & & & & & & $x$ & & \\
\hline UE-25 UZ\#4 & Modern & & & & $\bar{x}$ & & & & & & & \\
\hline UE-25 UZ\#5 & Modern & & & & $\mathrm{X}$ & & & & & & & \\
\hline USW UZ-6 & Historical & & & & & $\bar{x}$ & & $\bar{x}$ & & & & \\
\hline USW UZ-7A & Modern & & & & & & $\bar{x}$ & & & & $\bar{X}$ & \\
\hline USW UZ-14 & Modern & & $\bar{x}$ & & & & & & & $\bar{x}$ & & \\
\hline UE-25 UZ\#16 & Modern & & & & & & & & & & & \\
\hline USW WT-1 & Historical & & & & & & $x$ & & $\mathrm{x}$ & $\mathrm{X}$ & & \\
\hline USW WT-2 & Historical & & & & & & & & & & $\bar{x}$ & \\
\hline UE-25 WT\#3 & Historical & & & & & & & & & $\mathrm{X}$ & & $\bar{x}$ \\
\hline UE-25 WT\#4 & Historical & & & $x$ & $x$ & & & & & & & \\
\hline UE-25 WT\#6 & Historical & $\bar{x}$ & & & & & & & & & & \\
\hline USW WT-7 & Historical & & & & & $\bar{x}$ & & & & & & \\
\hline USW WT-10 & Historical & & & & & & & & & & & \\
\hline USW WT-11 & Historical & & & & & & & $\bar{x}$ & $X$ & & & $x$ \\
\hline USW WT\#12 & Historical & & & & & & $\bar{x}$ & & & & & $\bar{x}$ \\
\hline UE-25 WT\#13 & Historical & & & $\bar{x}$ & & & & & $\bar{x}$ & & & \\
\hline UE-25 WT\#14 & Historical & & & $x$ & & & & & & & & \\
\hline UE-25 WT\#15 & Historical & $\bar{x}$ & & & $\bar{X}$ & & & & & & & \\
\hline UE-25 WT\#16 & Historical & $\bar{x}$ & $\bar{x}$ & & & & & & & & & \\
\hline UE-25 WT\#17 & Historical & & & & & & $\bar{x}$ & & & & & \\
\hline UE-25 WT\#18 & Historical & & $\bar{X}$ & $\bar{x}$ & & & & & & & & \\
\hline USW WT-24 & Modern & & & $x$ & & & & & & & & \\
\hline
\end{tabular}




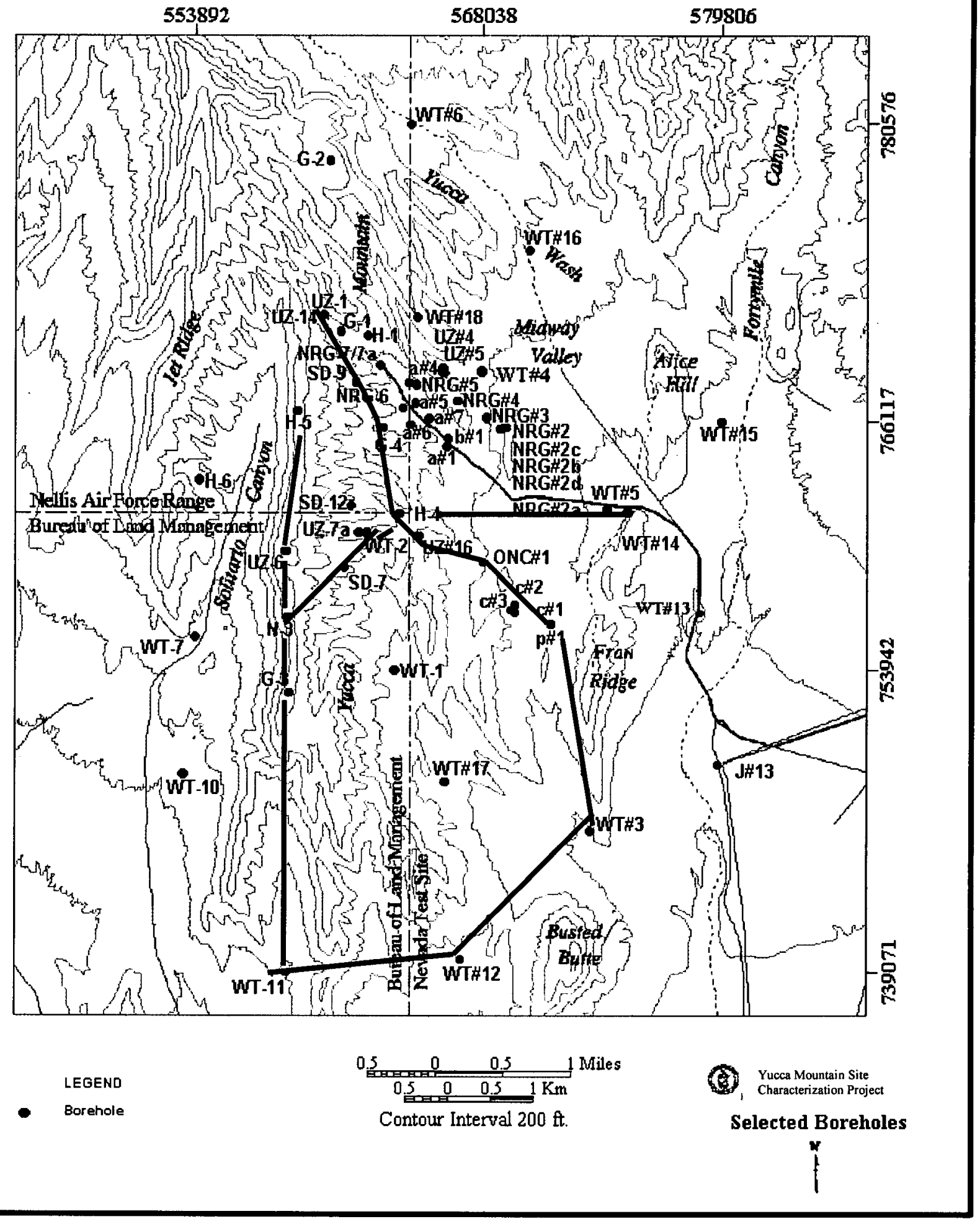

Figure 12. Generalized Borehole Locations (after Rael 2001) 
In the cross-section Plates A through $\mathrm{K}$, the datum is the top of the borehole and the log data are measured in feet below the surface. Diagnostic lithologic intervals discussed in this technical assessment include intervals bounding and/or initiating high porosity zones:

- Tpcpv2 - Tiva Canyon non-partly-welded vitric zones, occurring below the Tiva Canyon Tuff lower vitrophyre (Tptrv3)

- Tptrv2 - Topopah Spring upper non-partly-welded zones, occurring above a densely welded vitric zone (Tptrv1)

- Tptpv2 - Topopah Spring non-partly welded vitric zone, occurring below densely welded vitric zone (Tptpv3).

Rael (1999) shows these selected geologic contacts in borehole cross-sections Plates A through $\mathrm{K}$ to correlate zones of high porosity and bound water. Figure 13 shows a generalized porosity $\log$ labeled with these diagnostic intervals.

Less diagnostic, are older Tertiary volcanic units, including high porosity zones of the older Calico Hills units (Tac), and three important hydrogeologic units - the Prow Pass Tuff (Tcp), Bullfrog Tuff $(\mathrm{Tcb})$ and Tram Tuff (Tct). These units contain alternating sequences of nonwelded and welded tuffs, and are typified by alternating sequences of zones with and without bound water below the Tptpv1.

Data Qualification Team members reviewed all of the cross-section plates listed in Table 3 from Rael (1999). The following are brief discussions of selected cross-sections that contain colocated boreholes, modern and historical boreholes, and/or cross-sections with boreholes of comparable top-of-hole elevations. Cross-sections with boreholes of similar elevation, uninterrupted or mildly affected by regional north-south faulting, enable assessment of consistency of the porosity results and the regional geology as represented by the marker beds discussed above.

\section{Plate G}

This cross-section is oriented north-south along the Yucca Mountain Crestline well east of the Solitario Canyon fault. From north to south they include USW H-5, USW UZ-6, USW H-3, USW G-3, and USW WT-11. See Figure 13. All boreholes in Plate G are historical boreholes. The 4 northernmost are comparable in borehole elevation and uninterrupted by major north-south faults. All clearly show the diagnostic Tpcpv2 - Tptrv2 porosity pattern and the expected shallowing of the interval to the south. This profile is consistent with the base of the Topopah Spring shown in co-located cross-sections published in Scott and Bonk (1984; cross-section G) and Potter et al., (1998; cross-section C). 


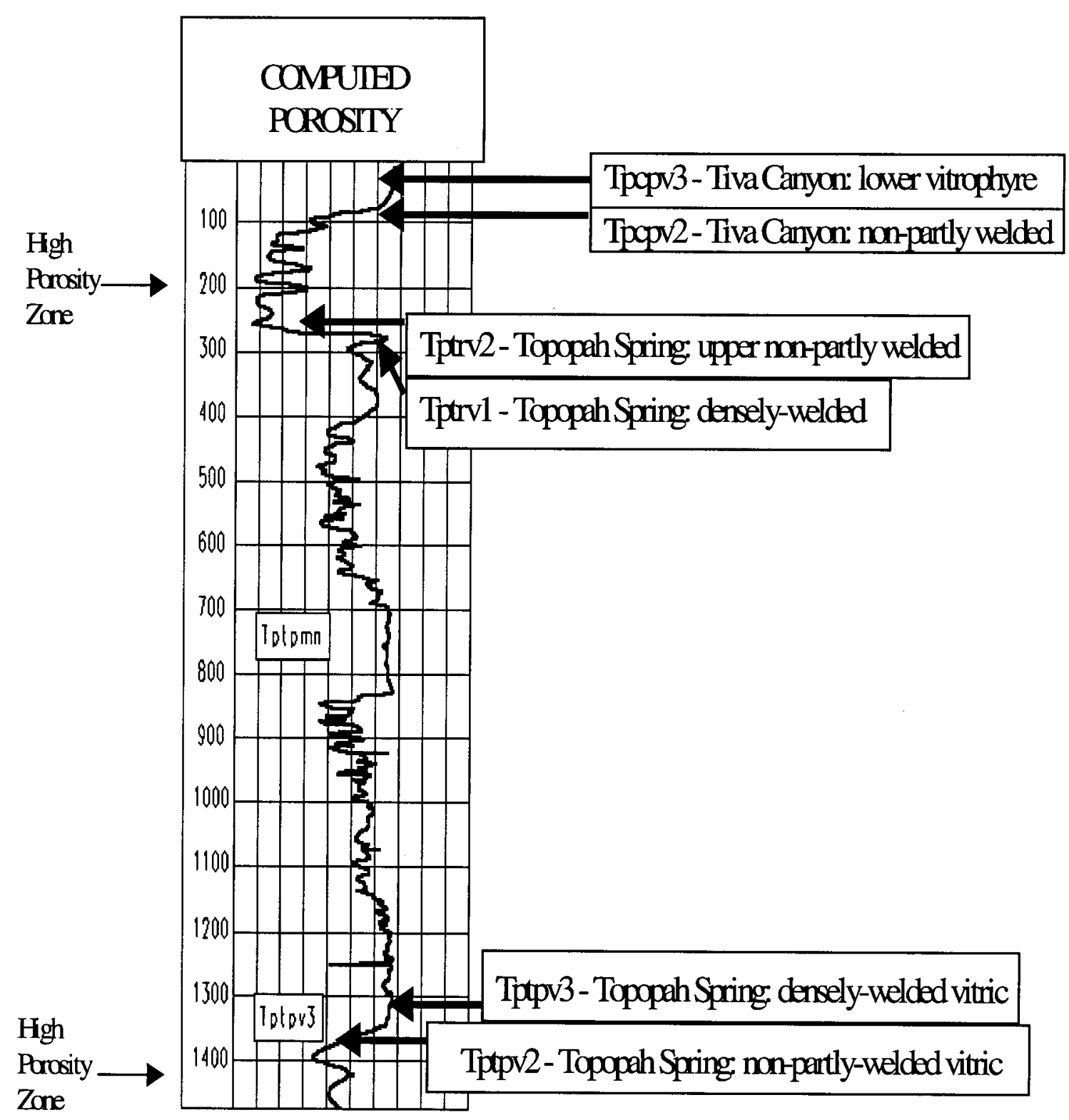

Figure 13. Generalized Diagnostic Changes in Calculated Porosity at Selected Lithologic Intervals with Depth (in feet) 


\section{Plate I}

This cross-section has three segments of different orientation containing both modern and historical boreholes. From north to south:

- Segment 1 - first segment is oriented north-northeast and includes USW UZ-14 (Modern), USW UZ-1 (Historical), USW SD-9 (Modern), and USW G-4 (Historical). The northernmost boreholes USW UZ-14 and USW UZ-1 are co-located in Drillhole Wash at the same elevation. Given the inherent variability from borehole to borehole, the Tpcpv2 - Tptrv2 high-porosity signatures are essentially identical and occur at the same depth. USW G-1 and USW SD-9 repeat the same corresponding pattern at the same lithologic interval.

- Segment 2 - second segment is oriented west-northwest and includes USW H-4 (Historical), UE-25 UZ \#16 (Modern), UE-25 ONC\#1 (Modern) and UE-25 p\#1 (Historical). Occurring within Antler Wash, USW H-4 and UE-25 UZ \#16 are separated laterally by approximately 1200 feet. Both boreholes show the base of the diagnostic high porosity/boundwater Tpcpv2 - Tptrv2 high-porosity interval at 250 feet and 225 feet below the surface, respectively. UE-25 ONC\#1 and UE-25 p\#1 show the same corresponding pattern at the same lithologic interval; however, the signature in UE-25 ONC\#1 occurs several hundred feet below the others. This relative off-set is consistent with geologic cross-sections by Scott and Bonk (1984). UE-25 ONC\#1 and UE-25 p\#1 lie in fault blocks west of the Bow Ridge Canyon Fault, where UE-25 p\#1 is also located on the down-dropped side of the Paint Brush Canyon Fault. In this case, the Tpcpv2 Tptrv2 porosity interval is distinctive and consistent with regional geology .

- Segment 3 - The third segment is oriented north-northwest, extending from UE-25 p\#1 (Historical) to UE-25 WT\#3 (Historical). The geologic interval Tpcpv2 - Tptrv2 does not occur at the location of UE-25 WT\#3.

\section{Plate J}

This is an east-west cross-section including from west to east USW H-3 (Historical), USW SD-7 (Modern), USW WT-2 (Historical), USW UZ-7A (Modern), USW H-4 (Historical), UE-25 WT\#14 (Historical). USW WT-2 and USW UZ-7A are relatively co-located and represent a corroboration of historical and modern boreholes. Again, some variability is expected from borehole to borehole; however, the Tpcpv2 - Tptrv2 high-porosity/bound water patterns are essentially identical. Although USW WT-2 is slightly down-dropped relative to USW UZ-7A, the off-set is consistent with faulting in the immediate vicinity (Potter et al 1998).

\section{Plate K}

This is an east-west cross-section through historical boreholes of similar elevation: USW WT11, UE-25 WT\#12, and UE-25 WT\#3. From USW WT-11 to UE-25 WT\#12, the diagnostic Tptrv2 - Tpcpv2 porosity pattern gently dips to the east. A geologic cross-section in this same 
area generally shows individual fault blocks with the same structure and stratigraphy with interceding off-sets at north south-trending faults (Potter et al 1998).

\subsubsection{Bound Water}

Rael's (1999) report emphasizes the location of bound water in his discussion of the oversize plates $\mathrm{A}-\mathrm{K}$ as the shaded difference between total porosity and effective porosity. Bound water DTN MO9910POROCALC.000 is calculated as the difference between total porosity oven-dried at $105^{\circ} \mathrm{C}$ and effective porosity oven-dried at $60^{\circ} \mathrm{C}$ and 65 percent relative humidity. The assumption is that subtracting the effective porosity, representing pore water able to flow under hydraulic gradient, leaves only the bound water chemically or physically bound to the rock.

Intervals in boreholes where XRD data are relied upon, where no RH matrix density curve could be constructed, Rael (1999) calculates effective porosity as the difference between total porosity and neutron porosity plus the volumetric water content. In his discussion of Plates A, B, and C, Rael (1999) casts uncertainty in the non-cored historical boreholes. In some cases, the method appears to overestimate bound water (e.g. UE-25 WT\#18, UE-25 WT\#4) or lack of continuity or accuracy (e.g. USW H-1, USW G-1 and UE-25 WT\#4).

In general, the Data Qualification Team's independent review of the bound water results is favorable. The output appears correlated with expected transport pathways in the Prow Pass, Bull Frog and Tram Members of the Calico Hills Formation and within the upper volcanic aquifer within the Paint Brush Group. The greatest uncertainty associated with the model results involve intervals in boreholes using the alternative "effective porosity" equation not supported by core measurements. However, boundwater was not included in the original DTN from Rael (1999) and the data are not within the scope of this qualification.

\subsubsection{Cross-Sections Discussion}

Independent review of all cross-section plates A-K by the Data Qualification Team shows agreement of the computed porosity output with the expected regional geologic trends associated with the diagnostic intervals. The plates show reasonable lateral continuity of the geophysical signatures between boreholes with expected minor off-sets caused by north-south trending faults shown on Scott and Bonk (1984) and Potter et al. (1998).

\section{EVALUATION RESULTS AND CONCLUSIONS}

Using corroboration and technical assessment, this qualification evaluation addresses a number of quality-affecting issues affecting both the historical and modern boreholes used to compute the porosity results presented in DTN MO9910POROCALC.000 and the superseding DTNs separated into modern and historical data sets (DTNs MO001OCPORGLOG.003 and MO0010CPORGLOG.002, respectively). This evaluation also addresses the data in DTN MO0105CPORGLOG.004 used in the porosity calculations for historical boreholes. The porosity and porosity-derived values computed for the historical and modern borehole data sets are adequate based on several general lines of reasoning. 
- Reproduction of the neutron data and identification of correlation between neutron porosity and other measured borehole parameters (e.g. bulk density) in the forensic evaluations of the historical boreholes.

- Visual corroboration of the modern data set based on a comparison of core porosities and geophysical-based porosities evident from plots of five modern boreholes.

- Linear correlation of all geophysical-based porosities and core porosities for each stratigraphic interval using historical and modern logs

- Comparable porosity and neutron porosity results for four boreholes (USW G-2, USW WT-2, USW WT-10, UE-25 WT \#12) generated using historical and modern inputs. This comparison augments the technical assessment involving the forensic analyses of USW H-6 and UE-25 $\# 1$ and further substantiates the adequacy of all primary historical geophysical inputs and the porosity calculations.

- Confirmative assessment of the geologic continuity of stratigraphic sequences from borehole to borehole inferred from porosity logs and stratigraphic intervals shown in cross-sections in Rael (1999).

The results of the evaluation for the historical data set are summarized as responses to the evaluation criteria described in Section 2.4.

1. Are the geophysical logs and other input parameters used in porosity calculations documented?

As summarized in this qualification report, Rael (1999) documents the geophysical logs and input parameters to the porosity-density equations used to compute porosity and porosity-derived output. For each historical and modern borehole listed in Table 1, Rael (1999, Appendices B and C) documents the original run logs and geophysical parameters used in the porosity calculations (e.g. NBC- Thermal Neutron Porosity curve, PHINBCcalibrated NBC, raw epithermal neutron data - ENP, PHIWENP-Epithermal Neutron Porosity curve, DBC - Bulk Density).

Density corrections applied to bulk density curves, matrix densities obtained from core porosities and XRD data, and parameter editing are described adequately (Rael, 1999; e.g. Table 3, Plates A-K). Associated input and output values and computer files corresponding to the historical and modern boreholes in Table 1 are listed in Rael (1999; Appendices B through F) and have been incorporated into DTNs for qualification. Modern borehole data is available through the forensic evaluations of modern boreholes.

2. Are the methods for determining porosity and porosity-derived values reproduced and documented? 
Rael (1999) documents the calculations used to compute porosity and porosity-derived values in Appendix $G$ of that document. Using the input and interim output variable names from Appendices B through F, Appendix $G$ shows the calculations and programming used for each borehole. The two forensic evaluations also provide an independent reproduction of the compositing and computational methods used by Nelson (1996) and the approach adopted and documented by Rael (1999) for the historical data set.

Augmented by further clarification of the use of porosity core data values in other boreholes as analog values, the methodology is described in enough detail in Rael (1999) to enable the use of the output data by a potential user on the YMP. Uncertainties discussed in this report should be considered, including the lack of continuity or the accuracy of calculated bound water in the following boreholes: UE-25 WT\#18, UE-25 WT\#4, USW H-1, USW G-1 and UE-25 WT\#4. In general, Rael (1999) does provide a good indicator of the presence or absence of bound water; however, this data is not included in the DTNs to be qualified.

3. Are resulting porosity and porosity-derived values as presented in Rael (1999) corroborated or technically justified as representing the properties of interest?

The output is computed total porosity, effective porosity, and volumetric water content on a foot-by-foot basis for each borehole. Technical assessment and corroboration occur in several different approaches and those involving comparison with core porosity are discussed under criterion \#5.

The availability of modern and historical borehole data sets for the same borehole allowed a comparison of porosities, limiting as variables the age of the data and/or methodology. The analyses augment the forensic evaluation for boreholes UE-25 p\#1 and USW H-6 by addressing the historical data sets for boreholes USW G-2, USW WT10, UE-25 WT\#12 and USW WT-2. Overall, the pattern of total porosity results derived using the old and modern data sets are comparable, as shown in Figures 8 through 11. As discussed in Section 3.3, Rael (1999) showed a similar result that compared neutron porosity data from the old and modern data sets.

The comparability of the porosity and neutron porosity data provides further justification for the acceptability of the modern and historical borehole data sets. The analysis suggests there is inherent variability in all modern and historical geophysical measurements, variability not only related to data collection under a qualified program, but also influenced by the tools used and/or the modern borehole condition. Consequently, the assessment determines that the accuracy of the geophysical data acquisition in older boreholes are adequate for use in quality affecting activities, including porosity calculations conducted by Rael (1999). 
4. Does the porosity/porosity-derived output from DTN MO9910POROCALC.000, presented in Rael (1999) as a series of cross-sections, show lateral lithostratigraphic continuity with adjacent boreholes?

Computed total porosity and volumetric water content are corroborated as discussed in criterion \#3 and in the series of Figures 2 through 6 of this report. Independent examination of the cross-sections A-K show reasonable geologic and hydrologic lateral continuity regarding total porosity and bound water. Major shifts in lower porosity, higher bound water and higher volumetric water content appear to be mutually corroborative. The major shifts are also consistent with an accepted hydrogeologic conceptual model where flow and transport is expected to be dominated within the Prow Pass, Bull Frog and Tram Members of the Calico Hills Formation and within the upper volcanic aquifer within the Paint Brush Group. The Data Qualification Team also finds that these properties demonstrate a reasonable regional geologic continuity in comparable boreholes.

5. Are measured porosity values from core consistent with geophysical porosity logs?

Corroboration is demonstrated between calculated porosities and core measured porosities in modern boreholes from figures presented in Rael (1999) and in comparison between a population of core porosites and log porosities averaged over stratigraphic intervals.

Reproduced from Rael (1999), porosity data shown in Figures 2 through 6 are measurements on core samples representing very small sample volumes with expected uncertainty in representativeness. As a consequence, using the more continuous bulk density data provides a reasonable and technically sound method to scale the porosity data to formational scales. In general, the two measures of porosity show the same pattern and are mutually corroborative. Where calculated porosities show less agreement in Figures 2 through 6, calculated values are consistently greater. Computed volumetric water content obtained from neutron-density data is also corroborated with coremeasured water volume data in Figures 6 through 7.

Figure 7 presents a comparison of total porosity data measured from laboratory core data and modern and historical geophysical logs averaged over the thickness of each stratigraphic interval in Rael's (1999) analysis. The cross-plot of the data shows a linear trend correlating core porosity data and modern and historical porosity data obtained from logs and substantiate porosity results that include both the modern and historical borehole data sets.

While Figures 2 through 6 corroborate only the modern borehole data set, it is important to emphasize that core porosity calculations for historical boreholes relied on the same equations, methods and input as applied to modern boreholes. Consequently, the corroboration of the modern boreholes by Rael (1999) and the linear trend established in Figure 7 provides confidence in the porosities computed for both modern and historical borehole data sets. 
6. Do the forensic analyses of the historical boreholes reproduce Nelson (1996) neutron porosity data?

The forensic evaluations of USW H-6 and UE-25 p\#1 plotted the neutron porosity data using the Nelson (1996) calibration procedure against the raw data with the appropriate transforms applied and documented. The comparison resulted in a one-to-one correspondence over all ranges using the same input parameters.

The independent forensic evaluations also provide the basis for establishing the accuracy of other historical geophysical logging conducted by Dresser-Atlas and Birdwell logging companies. Although the forensic evaluations validate adequate implementation of industry standard methods in the data acquisition for two historical boreholes, the evaluation also provides confidence in the data acquisition for all historical boreholes. Dresser-Atlas and Birdwell acquired the majority of historical geophysical data, including natural gamma ray spectroscopy, gamma ray, resistivity, caliper, density, compensated neutron, epithermal neutron and sonic data.

7. Do the forensic analyses of the historical boreholes document the data manipulation used to create composite geophysical logs?

The independent forensic evaluations provided by Olsen and Rael (2001) and Rael (2001) demonstrate the traceability of the algorithms applied to the Nelson (1996) thermal and epithermal neutron logs used by Rael (1999), specifically the algorithms applied to computations and air and water. In addition, NUE_POR, Version 0 software (STN: 10488-0-00) used in the forensic evaluations duplicate undocumented procedures used by Nelson (1996), including data selection (e.g. to select appropriate neutron data) and methods to interpolate within the borehole.

\section{RECOMMENDATIONS}

Based on the cumulative confirmatory responses to the evaluation criteria, this report concludes that the pre-PVAR output results calculated using modern and historical borehole data sets are valid. The historical neutron data are also assessed as being adequate for quality-affecting work and the bulk density data are already qualified. The other remaining input is the matrix density parameters used to differentiate between effective and total porosity. The Data Qualification Team addressed the matrix density parameters and found the development of the parameters to be adequately documented in Rael (1999). Consequently, these input parameters are considered adequate for quality affecting work. Likewise, developed as an interim parameter from neutron data, volumetric water content is also considered as part of the methodology assessed in this qualification through technical assessment and corroboration. Unqualified core density data and mineralogical data used to develop the matrix densities are not recommended to be qualified in this activity.

Based on the preponderance of evidence approach discussed in the recommendation criteria, three DTNs created as a consequence of this qualification activity should be qualified for 
generalized use on the YMP. As previously discussed in Section 1.2, original DTN MO9910POROCALC.000 has been divided into two new DTNs which are both recommended for qualification:

- MO0010CPORGLOG.002: This DTN contains the porosity results and developed input representing historical boreholes drilled and tested prior to 1991.

- MO0010CPORGLOG.003: This DTN contains porosity results and developed input representing modern boreholes drilled and/or tested under the QARD.

A third DTN MO0105CPORGLOG.004 includes all neutron log data referenced as input to the historical composite neutron porosities in DTN MO0010CPORGLOG.002. The Data Qualification Team recommends this data be qualified based on the technical assessment and corroboration discussed in response to the evaluation criteria. The neutron data in this DTN should be qualified for quality-affecting work along with all other already qualified geophysical data in the historical borehole data set.

The original DTN MO9910POROCALC.000 should remain unqualified.

\section{REFERENCES}

\subsection{DOCUMENTS CITED}

Asquith G., Gibson, C. 1982. Basic Well Log Analysis for Geologists. Tulsa, Oklahoma: American Association Of Petroleum Geologists. TIC: 210175.

(Asquith and Gibson 1982)

Atlas Wireline Services 1985. Log Interpretation Charts. Houston, Texas: Atlas Wireline Services. TIC: 245908 .

(Atlas 1985)

Carmichael, R.S. 1989. CRC Practical Handbook of Physical Properties of Rocks and Minerals. Boca Raton, Florida: CRC Press. TIC: 203668.

(Carmichael 1989)

CRWMS M\&O 1995. Technical Assessment, Borehole Geophysical Data. SCPB: 8.3.1.4.2.1.

Las Vegas, Nevada: CRWMS M\&O. ACC. MOL.19960320.0001.

(CRWMS M\&O 1995)

CRWMS M\&O 1996a. Determining Porosity, Balanced Water Content, and Other Rock Properties from Geophysical Logs for the Modern Borehole Data Set at Yucca Mountain, Nevada, June 1996. BAAA00000-01717-0200-00013, Rev. 00. Las Vegas, Nevada: CRWMS M\&O. ACC: MOL.19970210.0171 (Data).

(CRWMS M\&O 1996a) 
CRWMS M\&O 1996b. Synthesis of Borehole and Surface Geophysical Studies at Yucca Mountain, Nevada and Vicinity, Volume II: Borehole Geophysics, Part 1 "Status of Borehole Geophysics", and Part 2 "Preliminary Interpretative Summary of Geophysical logs from The Modern Borehole Data Set in Support of the Yucca Mountain Site Characterization Project. BAAA00000-01717-0200-00015, Rev. 00. Las Vegas, Nevada: CRWMS M\&O. ACC: MOL.19970114.0138.

(CRWMS M\&O 1996b)

CRWMS M\&O 1996c. Forensic Evaluation of Geophysical Log Data for Borehole USW SD-7 in Support of the Yucca Mountain Site Characterization Project. BAAA00000-01717-020000007, Rev. 00. Las Vegas, Nevada: CRWMS M\&O. ACC: MOL.19971023.0133. ACC: MOL.19971023.0133 (Modern Data).

(CRWMS M\&O 1996c)

CRWMS M\&O 1996d. Forensic Evaluation of Geophysical Log Data for Borehole USW SD-9 in Support of the Yucca Mountain Site Characterization Project. BAAA00000-01717-020000005, Rev. 00. Las Vegas, Nevada: CRWMS M\&O. ACC: MOL.19970606.0345. ACC: MOL.19970606.0344 (Modern Data).

(CRWMS M\&O 1996d)

CRWMS M\&O 1996e. Forensic Evaluation of Geophysical Log Data for Borehole USW SD-12 in Support of the Yucca Mountain Site Characterization Project. BAAA00000-01717-020000006, Rev. 00. Las Vegas, Nevada: CRWMS M\&O. ACC: MOL.19971022.0119. ACC: MOL.19971022.0121 (Modern Data).

(CRWMS M\&O 1996e)

CRWMS M\&O 1996f. Forensic Evaluation of Geophysical Log Data for Water Table Boreholes USW WT-2, USW WT-10, UE-25 WT\#12 in Support of the Yucca Mountain Site Characterization Project. BAAA00000-01717-0200-00009, Rev. 00. Las Vegas, Nevada: CRWMS M\&O. ACC: MOL.19960605.0064. ACC: MOL.19960603.0038 (Historical Data, USW WT-2), MOL.19960605.0066 (Modern and Historical Data, USW WT-10), and MOL.19960606.0110 (Modern and Historical Data, UE-25 WT\#12).

(CRWMS M\&O 1996f)

CRWMS M\&O 1996g. Forensic Evaluation of Geophysical Log Data for Borehole USW G-2 in Support of the Yucca Mountain Site Characterization Project. BAAA00000-01717-0200-00010, Rev. 00. Las Vegas, Nevada: CRWMS M\&O. ACC: MOL.19960520.0070. ACC: MOL.19960520.0072 (Modern and Historical Data).

(CRWMS M\&O 1996g)

CRWMS M\&O 1996h. Forensic Evaluation of Geophysical Log Data for Borehole UE-25 UZ\#4 in Support of the Yucca Mountain Site Characterization Project. BAAA00000-017170200-00003, Rev. 00. Las Vegas, Nevada: CRWMS M\&O. ACC: MOL.19960409.0388. ACC: MOL.19960517.0018 (Modern Data).

(CRWMS M\&O 1996h) 
CRWMS M\&O 1996i. Forensic Evaluation of Geophysical Log Data for Borehole UE-25 UZ\#5 in Support of the Yucca Mountain Site Characterization Project. BAAA000000-01717-020000002, Rev. 00. Las.Vegas, Nevada: CRWMS M\&O. ACC: MOL.19960328.0051. ACC: MOL.19960516.0126 (Modern Data).

(CRWMS M\&O 1996i)

CRWMS M\&O 1996j. Forensic Evaluation of Geophysical Log Data for Borehole USW UZ-7a in Support of the Yucca Mountain Site Characterization Project. BAAA00000-01717-020000004, Rev. 00. Las Vegas, Nevada: CRWMS M\&O. ACC: MOL.19960429.0392. ACC: MOL.19960517.0082 (Modern Data).

(CRWMS M\&O 1996j)

CRWMS M\&O 1996k. Forensic Evaluation of Geophysical Log Data for Borehole USW UZ-14 in Support of the Yucca Mountain Site Characterization Project. BAAA00000-01717-

0200-00012, Rev. 00. Las Vegas, Nevada: CRWMS M\&O. ACC: MOL.19960522.0169. ACC: MOL.19960522.0171 (Modern Data).

(CRWMS M\&O 1996k)

CRWMS M\&O 19961. Forensic Evaluation of Geophysical Log Data for Borehole UE 25 UZ \#16 (VSP2) in Support of the Yucca Mountain Site Characterization Project. BAAA0000001717-0200-00011, Rev. 00. Las Vegas, Nevada: CRWMS M\&O. ACC: MOL.19970731.0700. ACC: MOL.19990406.0318 (Modern Data).

(CRWMS M\&O 19961)

CRWMS M\&O 1996m. Forensic Evaluation of Geophysical Log Data for North Ramp Geologic Boreholes in Support of the Yucca Mountain Site Characterization Project, UE-25 $N R G-2, U E-25 N R G-2 A, U E-25 N R G-2 B, U E-25 N R G-2 C, U E-25 N R G-2 D, U E-25 N R G-3, U E-$ $25 N R G-4, U E-25 N R G-5, U S W N R G-6$, USW NRG-7/7A. BAAA00000-01717-0200-00008, Rev. 00. Las Vegas, Nevada: CRWMS M\&O. ACC: MOL.19960805.0110. ACC: MOL.19970107.0092 (Historical and Modern Data, UE-25 NRG\#4), MOL.19970110.0048 (Historical and Modern Data, UE-25 NRG\#5), MOL.19970113.0071 (Modern Data, USW NRG6), MOL.19971023.0322 (Modern Data, USW NRG 7A).

(CRWMS M\&O 1996m)

CRWMS M\&O 1996n. Forensic Evaluation of Geophysical Log Data for Borehole UE-25 ONC\#1 in Support of the Yucca Mountain Site Characterization Project. BAAA00000-017170200-00001, Rev. 01. Las Vegas, Nevada: CRWMS M\&O. ACC: MOL.19960227.0262. ACC: MOL.19971022.0054 (Modern Data).

(CRWMS M\&O 1996n)

CRWMS M\&O 19960. Borehole Log Qualification Checklists. Las Vegas, Nevada: CRWMS M\&O. ACC: MOL.19960320.0014.

(CRWMS M\&O 19960)

CRWMS M\&O 1999a. Combined Porosity from Geophysical Logs. BAA000000-01717-020000003, Rev. 00. Las Vegas, Nevada: CRWMS M\&O. ACC: MOL.19991208.0437. 
(CRWMS M\&O 1999a)

CRWMS M\&O 1999b. Forensic Evaluation of Geophysical Log Data for Borehole USW WT-24 in Support of the Yucca Mountain Site Characterization Project. BAA000000-01717-020000001, Rev. 00. Las Vegas, Nevada: CRWMS M\&O. ACC: MOL.19991208.0435 (Modern Data).

(CRWMS M\&O 1999b)

CRWMS M\&O 1999c. Forensic Evaluation of Geophysical Log Data for Borehole USW SD6/USW SD-6ST1 in Support of the Yucca Mountain Site Characterization Project. BAA000000-01717-0200-00002, Rev. 00. Las Vegas, Nevada: CRWMS M\&O. ACC: MOL.19991208.0436 (Modern Data).

(CRWMS M\&O 1999c)

CRWMS M\&O 1999d. Technical Assessment of Borehole Geophysical Data. Las Vegas, Nevada: DOE CRWMS M\&O. ACC: MOL.19991027.0101.

(CRWMS M\&O 1999d)

CRWMS M\&O 2000a. Data Qualification Report: Composite Geophysical Logs. TDR-NBSGS-000005, Rev. 00. Las Vegas, Nevada: CRWMS M\&O. ACC: MOL.20000420.0400.

(CRWMS M\&O 2000a)

CRWMS M\&O 2000b. Rock Properties Model Analysis Model Report. MDL-NBS-GS-000004, Rev. 00, ICN 02. Las Vegas, Nevada: CRWMS M\&O. ACC: MOL.20010216.0001.

(CRWMS M\&O 2000b)

CRWMS M\&O 2001. Data Qualification Plan: Calculated Porosity Logs and Related Digital Composite Geophysical Logs for Use on the Yucca Mountain Project. DQP-NBS-GS-000006, Rev. 00. Las Vegas, Nevada: CRWMS M\&O. ACC: MOL.20010220.0006.

(CRWMS M\&O 2001)

Dana, E.S., Ford, W. E. 1932. Dana's Textbook Of Mineralogy - Fourth Edition. New York, New York: John Wiley \& Sons, Inc. TIC: 236756.

(Dana 1932)

Flint, L.E. 1998. Characterization of Hydrogeologic Units Using Matrix Properties, Yucca Mountain, Nevada. USGS Water Resources Investigations Report 97-4243. Denver, Colorado: U.S. Geological Survey. DTN: GS960908312231.004. ACC: MOL.19980429.0512.

(Flint 1998)

Gearhart Industries 1970. Formation Evaluation Data Handbook. Fort Worth, Texas: Gearhart Industries, Inc. TIC: 245906.

(Gearhart 1970) 
Nelson, P.H. and Anderson, L.A. 1992. Physical Properties of Ash Flow Tuff from Yucca Mountain, Nevada. DTN: GS920608314213.002. Denver, Colorado: U.S. Geological Survey. ACC: NNA.19920707.0061.

(Nelson and Anderson 1992)

Nelson, P.H. 1996. Computation of Porosity and Water Content from Geophysical Logs, Yucca Mountain, Nevada. USGS Open File Report 96-078. Denver, Colorado: U.S. Geological Survey. ACC: MOL.19980529.0444.

(Nelson 1996)

Olsen, D.C. and Rael, H.P. 2001. Forensic Evaluation of Geophysical Log Data and Qualification of Unqualified Geophysical Log Data for Borehole USW H-6 in Support of the Yucca Mountain Site Characterization Project. MIS-NBS-GE-000002, Rev. 00, Draft D. Las Vegas, Nevada: CRWMS M\&O. ACC: MOL.20010423.0560 (Modern Data).

(Olsen and Rael 2001)

Potter, C.J., Dickerson, R.P., Sweetkind, D.S., Drake, R.M., Sanjuan, C.A., Taylor, E.M., Fridrich, C.J., and Day, W.C. 1998. Geologic Map of the Yucca Mountain Region. DTN: GS991208314221.001. Denver, Colorado: U.S. Geological Survey. ACC: MOL.20000619.0615.

(Potter et al 1998)

Rael, H.P. 2001. Forensic Evaluation of Geophysical Log Data and Qualification of Unqualified Geophysical Log Data for Borehole UE-25 p\#1 in Support of the Yucca Mountain Site Characterization Project. MIS-NBS-GE-000001, Rev. 00, Draft D. Las Vegas, Nevada: CRWMS M\&O. ACC: MOL.20010423.0559 (Modern Data).

(Rael 2001)

Schlumberger Educational Services 1988. Schlumberger Log Interpretation Charts. Houston, Texas: Schlumberger Educational Services. TIC: 245907.

(Schlumberger 1988)

Scott, R.B., and Bonk, Jerry 1984. Preliminary Geologic Map of Yucca Mountain Nye County, Nevada with Geologic Sections. USGS Open-File Report 84-494. Denver, Colorado: U.S. Geological Survey. ACC: NNA.19890511.0105.

(Scott and Bonk 1984)

Vaniman, D.T. 1997. Technical Data Supplement - Mineralogic Variation in Drill Holes USW NRG-6, NRG-7/7A, SD-7, SD-12, and UZ\#14: New Data from 1996-1997 Analyses. DTN: LADV831321AQ97.001. Los Alamos, New Mexico: Los Alamos National Laboratory. ACC: MOL.19971029.0033 (Data Tables).

(Vaniman 1997) 
Vaniman, D.T. 1998. Revised Mineralogic Summary of Yucca Mountain, Nevada. DTN:

LADB831321AN98.002. Los Alamos, New Mexico: Los Alamos National Laboratory. ACC:

MOL.19980626.0245 (Data Tables).

(Vaniman 1998)

\subsection{CODES, STANDARDS, REGULATIONS, AND PROCEDURES}

AP-3.15Q, Rev. 2, ICN 1, Managing Technical Product Inputs. Washington, D.C.: U.S. Department of Energy, Office of Civilian Radioactive Waste Management. ACC: MOL.20001109.0051.

(AP-3.15Q)

AP-SI.1Q, Rev. 2, ICN 4, ECN 1, Software Management. Washington, D.C.: U.S. Department of Energy, Office of Civilian Radioactive Waste Management. ACC: MOL.20001019.0023.

(AP-SI.1Q)

AP-SIII.2Q, Rev. 0, ICN 3, Qualification of Unqualified Data and the Documentation of Rationale for Accepted Data. Washington, D.C.: U.S. Department of Energy, Office of Civilian Radioactive Waste Management. ACC: MOL.20001002.0152.

(AP-SIII.2Q)

NWI-GL-001Q, Rev. 0, ICN 1, Verification of Digital Geophysical Log Data. Washington, D.C.: U.S. Department of Energy, Office of Civilian Radioactive Waste Management. ACC: MOL.20010111.0015.

(NWI-GL-001Q)

NWI-GL-002Q, Rev. 0, ICN 2, Forensic Evaluation of Geophysical Log Data. Washington, D.C.: U.S. Department of Energy, Office of Civilian Radioactive Waste Management. ACC: MOL.20010111.0028.

(NWI-GL-002Q)

NWI-GL-003Q, Rev. 0, ICN 2, Analysis of Geophysical Logs and Associated Depth-Related Borehole Data. Washington, D.C.: U.S. Department of Energy, Office of Civilian Radioactive Waste Management. ACC: MOL.20010111.0041.

(NWI-GL-003Q)

\subsection{SOURCE DATA, LISTED BY DATA TRACKING NUMBER}

GS920508312231.012. USW UZ-N54 and USW UZ-N55 Analysis, 105C Oven-Dried Core. Submittal date: $5 / 14 / 92$

GS930108312231.006. USW UZ-N53 Analysis, 105C Oven-Dried Core. Submittal data: $10 / 5 / 92$.

GS940108312231.002. Data for Core Dried in RH Oven and 105C Oven for USW UZ-N31, UZ-N32, UZ-N33, UZ-N34, UZ-N35, UZ-N38, UZ-N58, UZ-N59, UE-25 UZN\#63 AND USW 
UZ-N64; Data for Core Dried in 105C Oven Only for USW UZ-N11, UZ-N15, UZ-N16, UZN17, UZ-N27, UZ-N36 AND UZ-N37. Submittal date: 1/14/94.

GS940408312231.004. Core Analysis of Bulk Density, Porosity, Particle Density, and In-Situ Saturation for 3 Neutron Boreholes, USW UZ-N57, UZ-N61, AND UZ-N62. Submittal date: 4/1/94.

GS940508312231.006. Core Analysis of Bulk Density, Porosity, Particle Density and In-Situ Saturation for Borehole UE-25 UZ\#16. Submittal date: 5/4/94.

GS940508312231.007. Lab Analyses of Core from 10 Neutron Holes Using Relative Humidity Dry Weights. Submittal date: 5/4/94.

GS950308312231.002. Laboratory Measurements of Core from USW SD-12 and Radial Boreholes. Submittal date: 3/2/95.

GS950408312231.004. Physical Properties and Water Potentials of Core from Borehole USW SD-9. Submittal date: $3 / 1 / 95$.

GS950408312231.005. Physical Properties and Water Potentials of Core from Borehole USW UZ-14. Submittal date: 3/9/95.

GS950608312231.007. Physical Properties and Water Content from Borehole USW NRG-6, from 3/19/94 to 3/27/95. Submittal date: 6/6/95.

GS951108312231.009. Physical Properties, Water Content, and Water Potential for Borehole USW SD-7. Submittal date: 9/26/95.

GS951108312231.010. Physical Properties and Water Content for Borehole USW NRG-7/7A. Submittal date: $9 / 26 / 95$.

GS951108312231.011. Physical Properties, Water Content, and Water Potential for Borehole USW UZ-7A. Submittal date: 9/26/95.

GS960808312231.004. Physical Properties, Water Content and Water Potential for Samples from Lower Depths in Boreholes USW SD-7 and USW SD-12. Submittal date: 8/30/96.

GS980708312242.010. Physical Properties of Borehole Core Samples, and Water Potential Measurements Using the Filter Paper Technique, for Borehole Samples from USW WT-24. Submittal date: $7 / 27 / 98$.

GS980808312242.014. Physical Properties of Borehole Core Samples and Water Potential Measurements Using the Filter Paper Technique for Borehole Samples from USW SD-6. Submittal date: $8 / 11 / 98$. 
LADB831321 AN98.002. Revised Mineralogic Summary of Yucca Mountain, Nevada. Submittal date: $5 / 26 / 98$.

LADV831321AQ97.001. Mineralogic Variation in Drill Holes. Submittal date: 5/28/97.

MO0003COMPLOGS.000. Composite Data Files for Borehole Geophysical Logs of the "G" Series, the "H" Series, and the "WT" Series and "P1" Boreholes. Submittal date: 3/8/00.

MO0003COMPLOGS.001. Composite Data Files for Borehole Geophysical Logs of the "A" Series, the "B" Series, the "C" Series, and the "UZ" Series Boreholes. Submittal date: 3/10/00.

MO0101XRDMINAB.001. XRD Analyses of Drill Core from Boreholes UE-25B\#1, USW G-1, USW G-3, USW GU-3, and USW G-4. Submittal date: 1/26/01.

MO960408314213.010. Qualified Geophysical Logs from Borehole UE-25P\#1. Submittal date: $4 / 3 / 96$.

MO960408314213.011. Qualified Geophysical Logs from Borehole UE-25 WT\#3. Submittal date: $4 / 3 / 96$.

MO960408314213.012. Qualified Geophysical Logs from Borehole UE-25 WT\#4. Submittal date: $4 / 3 / 96$.

MO960408314213.013. Qualified Geophysical Logs from Borehole UE-25 WT\#6. Submittal date: $4 / 3 / 96$.

MO960408314213.014. Qualified Geophysical Logs from Borehole UE-25 WT\#12. Submittal date: $4 / 3 / 96$.

MO960408314213.015. Qualified Geophysical Logs from Borehole UE-25 WT\#13. Submittal date: $4 / 3 / 96$.

MO960408314213.016. Qualified Geophysical Logs from Borehole UE-25 WT\#14. Submittal date: $4 / 3 / 96$.

MO960408314213.017. Qualified Geophysical Logs from Borehole UE-25 WT\#15. Submittal date: $4 / 3 / 96$.

MO960408314213.018. Qualified Geophysical Logs from Borehole UE-25 WT\#16. Submittal date: $4 / 3 / 96$.

MO960408314213.019. Qualified Geophysical Logs from Borehole UE-25 WT\#17. Submittal date: $4 / 3 / 96$.

MO960408314213.020. Qualified Geophysical Logs from Borehole UE-25 WT\#18. Submittal date: $4 / 3 / 96$. 
MO960408314213.021. Qualified Geophysical Logs from Borehole USW G-1. Submittal date: 4/3/96.

MO960408314213.022. Qualified Geophysical Logs from Borehole USW G-2. Submittal date: $4 / 3 / 96$.

MO960408314213.023. Qualified Geophysical Logs from Borehole USW G-3. Submittal date: 4/3/96.

MO960408314213.024. Qualified Geophysical Logs from Borehole USW G-4. Submittal date: 4/3/96.

MO960408314213.025. Qualified Geophysical Logs from Borehole USW GU-3. Submittal date: $4 / 3 / 96$.

MO960408314213.026. Qualified Geophysical Logs from Borehole USW H-1. Submittal date: $4 / 4 / 96$.

MO960408314213.027. Qualified Geophysical Logs from Borehole USW H-3. Submittal date: $4 / 4 / 96$.

MO960408314213.028. Qualified Geophysical Logs from Borehole USW H-4. Submittal date: $4 / 4 / 96$.

MO960408314213.029. Qualified Geophysical Logs from Borehole USW H-5. Submittal date: $4 / 4 / 96$.

MO960408314213.030. Qualified Geophysical Logs from Borehole USW H-6. Submittal date: $4 / 4 / 96$.

MO960408314213.035. Qualified Geophysical Logs from Borehole USW WT-1. Submittal date: $4 / 4 / 96$.

MO960408314213.036. Qualified Geophysical Logs from Borehole USW WT-2. Submittal date: $4 / 4 / 96$.

MO960408314213.037. Qualified Geophysical Logs from Borehole USW WT-7. Submittal date: $4 / 4 / 96$.

MO960408314213.038. Qualified Geophysical Logs from Borehole USW WT-10. Submittal date: $4 / 4 / 96$.

MO960408314213.039. Qualified Geophysical Logs from Borehole USW WT-11. Submittal date: $4 / 4 / 96$. 
MO9906GENRG77A.000. Q Geophysical Log Data, USW NRG-7/7A. Submittal date: 6/2/99. MO9906GEOLNRG4.000. Q Geophysical Log Data, UE-25 NRG\#4. Submittal date: 6/21/99. MO9906GEOLNRG5.000. Q Geophysical Log Data, UE-25 NRG\#5. Submittal date: 6/18/99. MO9906GEOLNRG6.000. Q Geophysical Log Data, USW NRG-6. Submittal date: 6/7/99. MO9906GEOUSWG2.000. Q Geophysical Log Data, USW NRG-2. Submittal date: 6/9/99. MO9906GEOLONC1.000. Q Geophysical Log Data, UE-25 ONC\#1. Submittal date: 6/22/99. MO9906GEOLOSD9.000. Q Geophysical Log Data, USW SD-9. Submittal date: 6/22/99. MO9907GEUSWSD7.000. Q Geophysical Log Data, USW SD-7. Submittal date: 7/7/99. MO9907GEUSWWT2.000. Q Geophysical Log Data, USW WT-2. Submittal date: 7/26/99. MO9907GUE25UZ4.000. Q Geophysical Log Data, UE-25 UZ\#4. Submittal date: 7/14/99. MO9907GUE25UZ5.000. Q Geophysical Log Data, UE-25 UZ\#5. Submittal date: 7/21/99. MO9907GUSWSD12.000. Q Geophysical Log Data, USW SD-12. Submittal date: 7/12/99. MO9907GUSWUZ7A.000. Q Geophysical Log Data, USW UZ-7A. Submittal date: 7/22/99. MO9907UE25UZ16.000. Q Geophysical Log Data, UE-25 UZ\#16. Submittal date: 7/29/99. MO9908GEOLUZ14.000. Q Geophysical Log Data, USW UZ\#14. Submittal date: 8/5/99. MO9908GEOLWT12.000. Q Geophysical Log Data, UE-25 WT\#12. Submittal date: 8/11/99. MO9908GEUSWT10.000. Q Geophysical Log Data, USW WT-10. Submittal date: 8/31/99. MO9910POROCALC.000. Combined Porosity from Geophysical Logs. Submittal date: $10 / 5 / 99$.

MO9911GEOLOSD6.001. Forensic Evaluation of Geophysical Log Data for Borehole USW SD-6/USW SD-6ST1 in Support of Yucca Mtn. Site Characterization Project. Submittal date: 11/23/99.

MO9911GEOLWT24.001. Forensic Evaluation of Geophysical Log Data for Borehole USW WT-24 in Support of Yucca Mtn. Site Characterization Project. Submittal date: 11/23/99

\subsection{OUTPUT DATA, LISTED BY DATA TRACKING NUMBER}


MO0010CPORGLOG.002. Calculated Porosity from Geophysical Logs Data from "Old 40" Boreholes. Submittal date: $10 / 16 / 00$.

MO0010CPORGLOG.003. Calculated Porosity Values at Depth Derived from Qualified Geophysical Log Data from Modern Boreholes. Submittal date: 10/16/00.

MO0105CPORGLOG.004. Neutron Porosity Logs from USGS Open File Report OFR 96-078 by Nelson, 1996. Submittal date: 5/10/01

\subsection{SOFTWARE}

CRWMS M\&O 2000c. Validation Test Report for QLA V2.2. Software Document Number: 10082-VTR-2.2-00. Software Tracking Number: 10082-2.2-00. Las Vegas, Nevada: CRWMS M\&O. ACC: MOL.20000906.0011.

(CRWMS M\&O 2000c) 
APPENDIX A

EXAMPLE INPUT DATA SHEETS FOR GEOPHYSICAL DATA, CORE DENSITY AND XRD DATA USED IN POROSITY CALCULATIONS, AND CORE POROSITY DATA 
Table A1. Sample Geophysical Data Input Sheet for UE-25 UZ-5 (after Rael 1999, Appendix C)

\begin{tabular}{|c|c|c|c|c|c|}
\hline \multicolumn{3}{|c|}{ CURVE GENEALOGY TABLE } & \multicolumn{3}{|c|}{ WELL: UE-25 UZ-5 } \\
\hline \multicolumn{6}{|c|}{ 1. RUN TYPE: Log Data from M\&O Geophysics } \\
\hline \multicolumn{2}{|c|}{ 2. PASS TYPE: Output } & $\begin{array}{l}2 \text { a. } \\
\text { MAIN }\end{array}$ & $2 \mathbf{b}$. & 2c. & $\begin{array}{l}\text { 3. LOGGING DATE: } \\
\text { N/A }\end{array}$ \\
\hline \multicolumn{2}{|c|}{$\begin{array}{l}\text { 4. LSO FILE NAME(S): } \\
\text { DTN }\end{array}$} & $\begin{array}{l}\text { 4a. } \\
\text { MO9907GEUE25UZ5.000 }\end{array}$ & $4 \mathbf{b}$ & 4c. & $\begin{array}{l}\text { 5. MEDIA TYPE: } \\
\text { Disk file }\end{array}$ \\
\hline \multicolumn{2}{|c|}{ 6. LBS FILE NAME(S): } & 6a. & 6b. & 6c. & $\begin{array}{l}\text { 7. MEDIA ID: } \\
\text { File Names }\end{array}$ \\
\hline 8. & 9. & $\begin{array}{l}10 \mathrm{a} . \\
\mathrm{GCN}\end{array}$ & $\begin{array}{l}\text { 10b. } \\
\text { GCN }\end{array}$ & $\begin{array}{l}10 c . \\
\text { GCN }\end{array}$ & REMARKS: \\
\hline Caliper & CALI & CALI & & & \\
\hline Density Correction & DRHO & DRHO & & & \\
\hline Bulk Density & RHOB & RHOB & & & \\
\hline Deep Resistivity & RILD & RILD & & & \\
\hline $\begin{array}{l}\text { Epithermal Neutron } \\
\text { Porosity }\end{array}$ & SNP & SNP & & & \\
\hline & & & & & \\
\hline & & & & & \\
\hline & & & & & \\
\hline & & & & & \\
\hline & & & & & \\
\hline & & & & & \\
\hline & & & & & \\
\hline & & & & & \\
\hline & & & & & \\
\hline & & & & & \\
\hline & & & & & \\
\hline & & & & & \\
\hline & & & & & \\
\hline & & & & & \\
\hline & & & & & \\
\hline & & & & & \\
\hline & & & & & \\
\hline
\end{tabular}


Table A2. Sample Geophysical Data Input Sheet for USW WT-2 (after Rael 1999, Appendix C)

CURVE GENEALOGY TABLE

WELL: USW WT.2

\begin{tabular}{|c|c|c|c|c|c|c|}
\hline \multicolumn{7}{|c|}{ 1. RUN TYPE: Data from USGS and M\&O Geophysics } \\
\hline \multicolumn{2}{|c|}{ 2. PASS TYPE: Output } & $\begin{array}{l}2 a, \\
\text { MAIN }\end{array}$ & $\begin{array}{l}2 \mathbf{b} . \\
\text { MAIN }\end{array}$ & $\begin{array}{l}2 \mathrm{c} . \\
\text { MAIN }\end{array}$ & MAIN & $\begin{array}{l}\text { 3. LOGGING } \\
\text { DATE: } \\
\text { N/A }\end{array}$ \\
\hline \multicolumn{2}{|c|}{$\begin{array}{l}\text { 4. LSO FILE NAME(S): } \\
\text { YMNTS } 2 / G R O U P / G E S / \\
\text { LOG_DATA/HISTORIC }\end{array}$} & $\begin{array}{l}\text { 4a. } \\
\text { KOLDNEW/ } \\
\text { W2_ORIG.DAT }\end{array}$ & $\begin{array}{l}\text { 4b. } \\
\text { OLDNEWI } \\
\text { W2_MIN.DAT }\end{array}$ & $4 c$. & 4d. & $\begin{array}{l}\text { 5. MEDIA TYPE: } \\
\text { Disk Files }\end{array}$ \\
\hline \multicolumn{2}{|c|}{$\begin{array}{l}\text { 6. LSO FILE NAME(S): } \\
\text { DTN }\end{array}$} & 6a. & 6 b. & 6c. & $\begin{array}{l}\text { 6d. } \\
\text { MO9907GEUSWWT2.000 }\end{array}$ & $\begin{array}{l}\text { 7. MEDIA ID: } \\
\text { File Names }\end{array}$ \\
\hline $\begin{array}{l}8 . \\
\text { CURVE TYPE: }\end{array}$ & 9. & $\begin{array}{l}10 \mathrm{a} . \\
\mathrm{GCN}\end{array}$ & $\begin{array}{l}10 \mathrm{~b} \\
\text { GCN }\end{array}$ & $\begin{array}{l}\text { 10c. } \\
\text { GCN }\end{array}$ & $\begin{array}{l}\text { 10d. } \\
\text { GCN }\end{array}$ & $\begin{array}{l}11 . \\
\text { REMARKS: }\end{array}$ \\
\hline Coliper & $\mathrm{CAL}$ & CAL & & & & \\
\hline $\begin{array}{l}\text { Epithermal Neulron } \\
\text { Porosity }\end{array}$ & NEU & & & NEU & & Modem data set \\
\hline $\begin{array}{l}\begin{array}{l}\text { Epithermal Neutron } \\
\text { Porosity }\end{array} \\
\text { Por }\end{array}$ & PHIWENP & & PHIWENP & & & Calibrated \\
\hline Bulk Density & RHOBED & & & & RHOBED & Modern data sel \\
\hline Buik Density & DBC & DBC & & & & \\
\hline $\begin{array}{l}\text { Grain Densily frotn } \\
\text { XRD }\end{array}$ & RHOG & RHOG & & & & \\
\hline Deep Resislivily & RILD & & & RILD & & Modern data sel \\
\hline Water Level & SWL & SWL & & & & \\
\hline & & & & & & \\
\hline & & & & & & \\
\hline & & & & & & \\
\hline & & & & & & \\
\hline & & & & & & \\
\hline & & & & & & \\
\hline
\end{tabular}


Table A3. Sample Geophysical Data Input Sheet for UE-25 p\#1 (after Rael 1999, Appendix C)

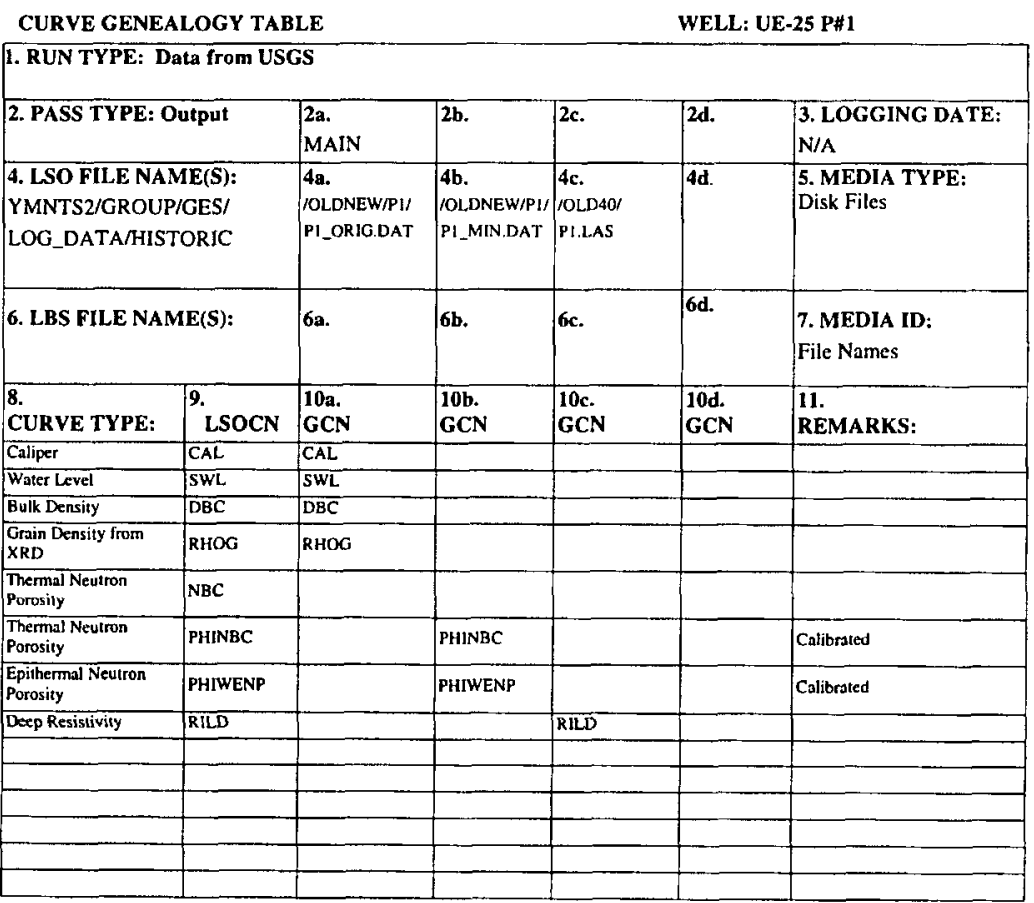


Table A4. Sample Geophysical Data Input Sheet for USW H-6 (after Rael 1999, Appendix C)

\begin{tabular}{|c|c|c|c|c|c|c|c|}
\hline \multicolumn{4}{|c|}{ CURVE GENEALOGY TABLE } & \multicolumn{4}{|c|}{ WELL: USW H-6 } \\
\hline \multicolumn{8}{|c|}{ 1. RUN TYPE: Data supplied by USGS } \\
\hline \multicolumn{2}{|c|}{ 2. PASS TYPE: Output } & $\begin{array}{l}2 \mathrm{a} . \\
\text { MAIN }\end{array}$ & $\begin{array}{l}2 b . \\
\text { MAIN }\end{array}$ & $\begin{array}{l}2 c . \\
\text { MAIN }\end{array}$ & $2 \mathrm{~d}$. & $2 e$. & $\begin{array}{l}\text { 3. LOGGING DATE: } \\
\text { N/A }\end{array}$ \\
\hline \multicolumn{2}{|c|}{$\begin{array}{l}\text { 4. LSO FILE NAME(S): } \\
\text { YMNTS } 2 / \text { GROUP/GES/ } \\
\text { LOG_DATA/HISTORIC }\end{array}$} & $\begin{array}{l}\text { 4a. } \\
\text { OLDNEW/ } \\
\text { H6_ORIG.DAT }\end{array}$ & $\begin{array}{l}\text { 4b. } \\
\text { /OLDNEW' } \\
\text { H6_MIN DAT }\end{array}$ & $\begin{array}{l}4 c . \\
\text { JOLD4N } \\
\text { H6.LAS }\end{array}$ & $4 d$. & $4 e$. & $\begin{array}{l}\text { 5. MEDIA TYPE: } \\
\text { Disk Files }\end{array}$ \\
\hline \multicolumn{2}{|c|}{ 6. LBS FILE NAME(S): } & $6 a$. & 6b. & 6c. & 6d. & $6 \mathbf{6 e .}$ & $\begin{array}{l}\text { 7. MEDIA ID: } \\
\text { File Names }\end{array}$ \\
\hline $\begin{array}{l}8 . \\
\text { CURVE TYPE: }\end{array}$ & 9. & GeN & $\begin{array}{l}10 \mathrm{~b} . \\
\mathrm{GCN}\end{array}$ & $\begin{array}{l}10 c . \\
\text { GCN }\end{array}$ & 10d. & $\begin{array}{l}10 \mathrm{e} \\
\text { GCN }\end{array}$ & $\begin{array}{l}11 . \\
\text { REMARKS: }\end{array}$ \\
\hline Caliper & CAL & CAL & & & & & \\
\hline Density Correction & CDCORI & & & DRHO & & & \\
\hline Densily Correction & CDCOR2 & & & DRHO2 & & & \\
\hline $\begin{array}{l}\text { Thermal Neutron } \\
\text { Porosity }\end{array}$ & NBC & NBC & . & & & & \\
\hline $\begin{array}{l}\text { Thermal Neutron } \\
\text { Porosity }\end{array}$ & PHINBC & & PHINBC & & & & Calibrated \\
\hline $\begin{array}{l}\text { Epichemmal Neutron } \\
\text { Poresity }\end{array}$ & PHIWENP & & PHIWENP & & & & Calibrated \\
\hline Bulk Densily & DBC & DBC & & & & & \\
\hline $\begin{array}{l}\text { Grain densily froun } \\
\text { XRD }\end{array}$ & Rнос & RHOG & & & & & \\
\hline Deep Resistivily & RILO & & & RILD & & & \\
\hline Water Level & SWL & SWL & & & & & \\
\hline & & & & & & & \\
\hline & & & & & & & \\
\hline & & & & & & & \\
\hline & & & & & & & \\
\hline
\end{tabular}


Table A5. Sample Geophysical Data Input Sheet for USW G-1 (after Rael 1999, Appendix C)

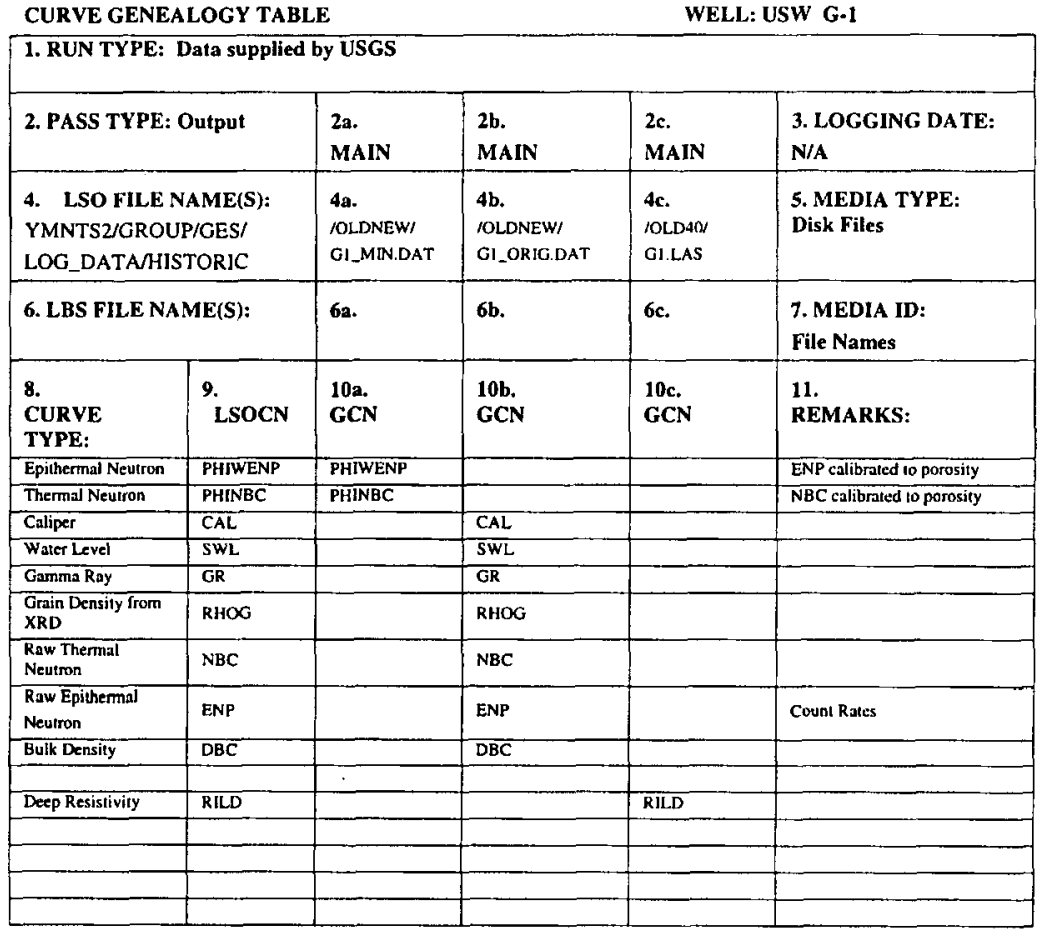


Table A6. Core Density Data used in Porosity Calculations (after Rael 1999, Appendix B)

\begin{tabular}{|c|c|c|c|c|}
\hline Borehole & Data Tracking Number & Accession Number & Q Status & Remarks \\
\hline \multirow[t]{2}{*}{ USW UZ-N11 } & GS940508312231.007 & MOL.19961113.0248 & UQ & RH Data \\
\hline & GS940108312231.002 & MOL.19961113.0246 & $\mathrm{Q}$ & $105^{\circ} \mathrm{C}$ data \\
\hline \multirow[t]{2}{*}{ USW UZ-N15 } & GS940508312231.007 & MOL.19961113.0248 & UQ, TBV & RH Data \\
\hline & GS940108312231.002 & MOL.19961113.0246 & $\mathrm{Q}$ & $105^{\circ} \mathrm{C}$ data \\
\hline \multirow[t]{2}{*}{ USW UZ-N16 } & GS940508312231.007 & MOL.19961113.0248 & UQ, TBV & RH Data \\
\hline & GS940108312231.002 & MOL.19961113.0246 & $Q$ & $105^{\circ} \mathrm{C}$ data \\
\hline \multirow[t]{2}{*}{ USW UZ-N17 } & GS940508312231.007 & MOL.19961113.0248 & UQ, TBV & RH Data \\
\hline & GS940108312231.002 & MOL.19961113.0246 & $\mathrm{Q}$ & $105^{\circ} \mathrm{C}$ data \\
\hline USW UZ-N31 & GS940108312231.002 & MOL.19961113.0246 & $\mathrm{Q}$ & \\
\hline USW UZ-N32 & GS940108312231.002 & MOL.19961113.0246 & $Q$ & \\
\hline USW UZ-N33 & GS940108312231.002 & MOL.19961113.0246 & $\mathrm{Q}$ & \\
\hline USW UZ-N34 & GS940108312231.002 & MOL.19961113.0246 & $Q$ & \\
\hline USW UZ-N35 & GS940108312231.002 & MOL.19961113.0246 & $\mathrm{Q}$ & \\
\hline \multirow[t]{2}{*}{ USW UZ-N36 } & GS940508312231.007 & MOL.19961113.0248 & UQ, TBV & RH Data \\
\hline & GS940108312231.002 & MOL.19961113.0246 & $\mathrm{Q}$ & $105^{\circ} \mathrm{C}$ data \\
\hline \multirow[t]{2}{*}{ USW UZ-N37 } & GS940508312231.007 & MOL.19961113.0248 & UQ, TBV & $\mathrm{RH}$ Data \\
\hline & GS940108312231.002 & MOL.19961113.0246 & $\mathrm{Q}$ & $105^{\circ} \mathrm{C}$ data \\
\hline USW UZ-N38 & GS940108312231.002 & MOL.19961113.0246 & $\bar{Q}$ & \\
\hline \multirow[t]{2}{*}{ USW UZ-N53 } & GS940508312231.007 & MOL.19961113.0248 & UQ, TBV & RH Data \\
\hline & GS930108312231.006 & MOL.19961113.0242 & $\mathrm{Q}$ & $105^{\circ} \mathrm{C}$ data \\
\hline \multirow[t]{2}{*}{ USW UZ-N54 } & GS940508312231.007 & MOL.19961113.0248 & UQ, TBV & RH Data \\
\hline & GS920508312231.012 & MOL.19961113.0240 & $\mathrm{Q}$ & $105^{\circ} \mathrm{C}$ data \\
\hline \multirow[t]{2}{*}{ USW UZ-N55 } & GS940508312231.007 & MOL.19961113.0248 & UQ, TBV & $\mathrm{RH}$ Data \\
\hline & GS920508312231.012 & MOL. 19961113.0240 & $Q$ & $105^{\circ} \mathrm{C}$ data \\
\hline USW UZ-N57 & GS940408312231.004 & MOL.19961113.0244 & $\mathrm{Q}$ & \\
\hline USW UZ-N58 & GS940108312231.002 & MOL.19961113.0246 & $\bar{Q}$ & \\
\hline USW UZ-N59 & GS940108312231.002 & MOL.19961113.0246 & $Q$ & \\
\hline USW UZ-N61 & GS940408312231.004 & MOL. 19961113.0244 & $\mathrm{Q}$ & \\
\hline USW UZ-N62 & GS940408312231.004 & MOL.19961113.0244 & $\mathrm{Q}$ & \\
\hline UE-25 UZ-N63 & GS940108312231.002 & MOL.19961113.0246 & $Q$ & \\
\hline USW UZ-N64 & GS940108312231.002 & MOL.19961113.0246 & $\mathrm{Q}$ & \\
\hline USW NAG-6 & GS950608312231.007 & $\begin{array}{l}\text { MOL. } 19960924.0766 \\
\text { (3.5" Disk) }\end{array}$ & $Q$ & $\begin{array}{l}\text { SEP tables S96039_001 to } \\
\text { S96039_006 }\end{array}$ \\
\hline USW NRG-7A & GS951108312231.010 & MOL.19960524.0208 & $Q$ & \\
\hline \multirow[t]{2}{*}{ USW SD-7 } & GS951108312231.009 & MOL.19960524.0203 & $\mathrm{Q}$ & Depth $<1602-\mathrm{ft}$ \\
\hline & GS960808312231.004 & MOL.19970513.0304 & $\mathrm{Q}$ & Depth $>1602-\mathrm{ft}$ \\
\hline USW SD-9 & GS950408312231.004 & MOL.19960924.0711 & $Q$ & \\
\hline \multirow[t]{2}{*}{ USW SD-12 } & GS950308312231.002 & $\begin{array}{l}\text { MOL.19960112.0216 } \\
\text { (3.5" Disk) }\end{array}$ & $Q$ & $\begin{array}{l}\text { SEP tables S96015_001 to } \\
\text { S96015_007 }\end{array}$ \\
\hline & GS960808312231.004 & MOL.19970513.0304 & $\mathrm{Q}$ & Depth $>1266-f t$ \\
\hline USW UZ-7A & GS951108312231.011 & MOL.19960524.0213 & $\mathrm{Q}$ & \\
\hline USW UZ-14 & GS950408312231.005 & MOL.19960924.0713 & Q, TBV & \\
\hline UE-25 UZ \#16 & GS940508312231.006 & MOL.19961113.0250 & $\mathrm{Q}$ & \\
\hline USW SD-6 & GS980808312242.014 & MOL.19980824.0222 & $Q$ & $\begin{array}{l}\text { SEP tables S98285_001 to } \\
\text { S98285_006 }\end{array}$ \\
\hline USW WT-24 & GS980708312242.010 & MOL.19980918.0391 & Q & $\begin{array}{l}\text { SEP tables S98248_001 to } \\
\text { S98248_006 }\end{array}$ \\
\hline
\end{tabular}

Notes for "Q Status" Column

\begin{tabular}{|l|l|}
\hline Q & Qualified \\
\hline UQ & Unqualified \\
\hline TBV & To Be Verified \\
\hline
\end{tabular}


Table A7. XRD Data used in Porosity Calculations

(after Rael 1999, Appendix B)

\begin{tabular}{|l|l|l|l|l|}
\hline \multicolumn{1}{|c|}{ Borehole } & Data Tracking Number & Accession Number & \multicolumn{1}{|c|}{ Q Status } & Qualified DTN \\
\hline UE-25 A\#1 & LADB831321AN98.002 & MOL.19980626.0245 & UQ-1, TBV & \\
\hline UE-25 B\#1 & LADB831321AN98.002 & MOL.19980626.0245 & UQ-1, TBV, 6 & MO0101XRDMINAB.001 \\
\hline USW G-1 & LADB831321AN98.002 & MOL.19980626.0245 & UQ-1, TBV, 6 & MO0101XRDMINAB.001 \\
\hline USW G-2 & LADB831321AN98.002 & MOL.19980626.0245 & UQ-1, TBV & \\
\hline USW G-4 & LADB831321AN98.002 & MOL.19980626.0245 & UQ-1, TBV, 6 & MO0101XRDMINAB.001 \\
\hline USW GU-3 & LADB831321AN98.002 & MOL.19980626.0245 & UQ-1, TBV, 6 & MO0101XRDMINAB.001 \\
\hline USW H-3 & LADB831321AN98.002 & MOL.19980626.0245 & UQ-4, TBV & \\
\hline USW H-3 & LADV831321AQ97.001 & MOL.19971029.0033 & Q-1, TBV & LADV831321AQ97.001 \\
\hline USW H-4 & LADB831321AN98.002 & MOL.19980626.0245 & UQ-4, TBV & \\
\hline USW H-5 & LADB831321AN98.002 & MOL.19980626.0245 & UQ-3, TBV & \\
\hline USW H-6 & LADB831321AN98.002 & MOL.19980626.0245 & UQ-1, TBV & \\
\hline J-12 & LADB831321AN98.002 & MOL.19980626.0245 & UQ-2, TBV & \\
\hline J-13 & LADB831321AN98.002 & MOL.19980626.0245 & UQ-1, TBV & \\
\hline USW NRG-6 & LADV831321AQ97.001 & MOL.19971029.0033 & Q-1, TBV & LADV831321AQ97.001 \\
\hline USW NRG-7A & LADV831321AQ97.001 & MOL.19971029.0033 & Q-1, TBV & LADV831321AQ97.001 \\
\hline UE-25 P\#1 & LADB831321AN98.002 & MOL.19980626.0245 & UQ-5, TBV & \\
\hline USW SD-7 & LADV831321AQ97.001 & MOL.19971029.0033 & Q-1, TBV & LADV831321AQ97.001 \\
\hline USW SD-9 & LADV831321AQ97.001 & MOL.19971029.0033 & Q-1, TBV & LADV831321AQ97.001 \\
\hline USW SD-12 & LADV831321AQ97.001 & MOL.19971029.0033 & Q-1, TBV & LADV831321AQ97.001 \\
\hline USW UZ-14 & LADV831321AQ97.001 & MOL.19971029.0033 & Q-1, TBV & LADV831321AQ97.001 \\
\hline USW WT1 & LADB831321AN98.002 & MOL.19980626.0245 & UQ-2, TBV & \\
\hline USW WT2 & LADB831321AN98.002 & MOL.19980626.0245 & UQ-3, TBV & \\
\hline
\end{tabular}

Notes for "Q Status" Column
\begin{tabular}{|l|l|}
\hline$Q$ & Qualified \\
\hline UQ & Unqualified \\
\hline 1 & Core \\
\hline 2 & Cuttings \\
\hline 3 & Cuttings and Core \\
\hline 4 & Sidewall and Cuttings \\
\hline 5 & Cuttings, Sidewall and Core \\
\hline 6 & $\begin{array}{l}\text { Report TDR-NBS-HS-000005 is qualifying } \\
\text { data in DTN MO0101XRDMINAB.001 }\end{array}$ \\
\hline TBV & To Be Verified \\
\hline
\end{tabular}


Table A8. Average Total Porosity Values from Both Cores and Logs

(Data for Figure 7)

\begin{tabular}{|c|c|c|c|c|c|c|}
\hline Interval & $\begin{array}{l}\text { Data } \\
\text { Source }\end{array}$ & $\begin{array}{l}\text { Number of } \\
\text { Samples }\end{array}$ & $\begin{array}{l}\text { Average } \\
\text { Porosity }\end{array}$ & $\begin{array}{l}\text { Standard } \\
\text { Deviation }\end{array}$ & Minimum & Maximum \\
\hline \multirow[t]{2}{*}{ Tpc_un } & CORES & 941 & 0.124 & 0.0687 & 0.0140 & 0.5000 \\
\hline & LOGS & 5580 & 0.117 & 0.0661 & 0.0033 & 0.4499 \\
\hline \multirow[t]{2}{*}{ Tpcpv2 } & CORES & 98 & 0.223 & 0.0996 & 0.0410 & 0.4560 \\
\hline & LOGS & 768 & 0.172 & 0.0585 & 0.0356 & 0.3670 \\
\hline \multirow[t]{2}{*}{ Tpcpv1 } & CORES & 89 & 0.363 & 0.0929 & 0.0990 & 0.6330 \\
\hline & LOGS & 671 & 0.309 & 0.0713 & 0.1261 & 0.6125 \\
\hline \multirow[t]{2}{*}{ Tpbt4 } & CORES & 47 & 0.415 & 0.1380 & 0.0900 & 0.6690 \\
\hline & LOGS & 390 & 0.359 & 0.0897 & 0.2134 & 0.8053 \\
\hline \multirow[t]{2}{*}{ Tpy } & CORES & 125 & 0.322 & 0.1017 & 0.0250 & 0.5400 \\
\hline & LOGS & 931 & 0.278 & 0.1337 & 0.0143 & 0.7452 \\
\hline \multirow[t]{2}{*}{ Tpbt3 } & CORES & 65 & 0.406 & 0.0886 & 0.1690 & 0.5780 \\
\hline & LOGS & 1904 & 0.349 & 0.0961 & 0.0172 & 0.5570 \\
\hline \multirow[t]{2}{*}{ Tpp } & CORES & 178 & 0.485 & 0.0435 & 0.3930 & 0.6150 \\
\hline & LOGS & 4021 & 0.363 & 0.1101 & 0.0824 & 0.5983 \\
\hline \multirow[t]{2}{*}{ Tpbt2 } & CORES & 141 & 0.498 & 0.0689 & 0.2870 & 0.6290 \\
\hline & LOGS & 1748 & 0.361 & 0.1010 & 0.1262 & 0.5846 \\
\hline \multirow[t]{2}{*}{ Tptrv3 } & CORES & 50 & 0.478 & 0.0873 & 0.2840 & 0.6080 \\
\hline & LOGS & 548 & 0.354 & 0.1137 & 0.0246 & 0.5712 \\
\hline \multirow[t]{2}{*}{ Tptrv2 } & CORES & 9 & 0.208 & 0.0974 & 0.0340 & 0.2980 \\
\hline & LOGS & 227 & 0.231 & 0.1020 & 0.0062 & 0.4203 \\
\hline \multirow[t]{2}{*}{ Tptrv1 } & CORES & 18 & 0.061 & 0.0751 & 0.0190 & 0.2730 \\
\hline & LOGS & 238 & 0.111 & 0.0731 & 0.0112 & 0.3741 \\
\hline \multirow[t]{2}{*}{ Tptrn } & CORES & 455 & 0.138 & 0.0482 & 0.0060 & 0.4220 \\
\hline & LOGS & 8659 & 0.144 & 0.0612 & 0.0024 & 0.5921 \\
\hline \multirow[t]{2}{*}{ Tptrl } & CORES & 52 & 0.156 & 0.0268 & 0.0960 & 0.2200 \\
\hline & LOGS & 1900 & 0.206 & 0.0583 & 0.0274 & 0.4452 \\
\hline \multirow[t]{2}{*}{ Tptpul } & CORES & 424 & 0.145 & 0.0353 & 0.0390 & 0.2890 \\
\hline & LOGS & 13388 & 0.217 & 0.0624 & 0.0359 & 0.4519 \\
\hline \multirow[t]{2}{*}{ Tptf } & CORES & 3 & 0.073 & 0.0058 & 0.0700 & 0.0800 \\
\hline & LOGS & 435 & 0.107 & 0.0336 & 0.0373 & 0.2113 \\
\hline \multirow[t]{2}{*}{ Tptpmn } & CORES & 328 & 0.102 & 0.0226 & 0.0460 & 0.1920 \\
\hline & LOGS & 8350 & 0.104 & 0.0396 & 0.0070 & 0.4800 \\
\hline \multirow[t]{2}{*}{ Tptpll } & CORES & 548 & 0.123 & 0.0363 & 0.0610 & 0.3320 \\
\hline & LOGS & 16860 & 0.173 & 0.0569 & 0.0192 & 0.4554 \\
\hline \multirow[t]{2}{*}{ Tptpln } & CORES & 392 & 0.096 & 0.0295 & 0.0350 & 0.2500 \\
\hline & LOGS & 9527 & 0.104 & 0.0421 & 0.0016 & 0.3809 \\
\hline Tptpv3 & CORES & 139 & 0.041 & 0.0345 & 0.0060 & 0.1450 \\
\hline & LOGS & 3432 & 0.047 & 0.0344 & 0.0011 & 0.2202 \\
\hline Tptpv2 & CORES & 47 & 0.136 & 0.0887 & 0.0120 & 0.3170 \\
\hline & LOGS & 1658 & 0.192 & 0.0919 & 0.0011 & 0.4387 \\
\hline Tptpv1 & CORES & 77 & 0.262 & 0.0792 & 0.0310 & 0.4150 \\
\hline & LOGS & 1899 & 0.296 & 0.0794 & 0.0108 & 0.4807 \\
\hline Tpbt1 & CORES & 14 & 0.250 & 0.0764 & 0.1350 & 0.3580 \\
\hline & LOGS & 709 & 0.285 & 0.0853 & 0.0608 & 0.4980 \\
\hline Tac & CORES & 500 & 0.294 & 0.0673 & 0.0090 & 0.4700 \\
\hline & LOGS & 10527 & 0.320 & 0.0753 & 0.0046 & 0.5514 \\
\hline Tacbt & CORES & 109 & 0.246 & 0.0748 & 0.0420 & 0.4180 \\
\hline & LOGS & 2277 & 0.266 & 0.0807 & 0.0341 & 0.4685 \\
\hline Tcp4v & CORES & 101 & 0.292 & 0.0548 & 0.1370 & 0.4360 \\
\hline & LOGS & 2096 & 0.333 & 0.0582 & 0.1165 & 0.4911 \\
\hline Tcp3n2c & CORES & 140 & 0.307 & 0.0398 & 0.2020 & 0.3950 \\
\hline & LOGS & 1843 & 0.340 & 0.0479 & 0.1863 & 0.4649 \\
\hline Tcp_red & CORES & 1 & 0.324 & & 0.3240 & 0.3240 \\
\hline & LOGS & 264 & 0.278 & 0.0617 & 0.1300 & 0.3950 \\
\hline
\end{tabular}


Table A8 (Continued). Average Total Porosity Values from Both Cores and Logs

\begin{tabular}{|c|c|c|c|c|c|c|}
\hline Interval & $\begin{array}{l}\text { Data } \\
\text { Source }{ }^{1}\end{array}$ & $\begin{array}{l}\text { Number of } \\
\text { Samples }\end{array}$ & $\begin{array}{l}\text { Average } \\
\text { Porosity }\end{array}$ & $\begin{array}{l}\text { Standard } \\
\text { Deviation }\end{array}$ & Minimum & Maximum \\
\hline \multirow[t]{2}{*}{ Tcp3md } & CORES & 154 & 0.214 & 0.0666 & 0.0750 & 0.3460 \\
\hline & LOGS & 3046 & 0.237 & 0.0772 & 0.0406 & 0.4053 \\
\hline \multirow[t]{2}{*}{ Tcp_orange } & CORES & 36 & 0.210 & 0.0702 & 0.0740 & 0.3500 \\
\hline & LOGS & 1883 & 0.206 & 0.0816 & 0.0022 & 0.3548 \\
\hline \multirow[t]{2}{*}{ Tcp13n1c } & CORES & 26 & 0.231 & 0.0383 & 0.1510 & 0.2940 \\
\hline & LOGS & 844 & 0.278 & 0.0816 & 0.0402 & 0.4494 \\
\hline \multirow[t]{2}{*}{ Tcp13n1V } & CORES & 227 & 0.244 & 0.0622 & 0.0990 & 0.3970 \\
\hline & LOGS & 3492 & 0.251 & 0.0763 & 0.0032 & 0.4286 \\
\hline \multirow[t]{2}{*}{ Tcpbt } & CORES & 11 & 0.233 & 0.0789 & 0.1360 & 0.3910 \\
\hline & LOGS & 477 & 0.250 & 0.0695 & 0.0354 & 0.4921 \\
\hline \multirow[t]{2}{*}{ Tcbn2v } & CORES & 12 & 0.279 & 0.0766 & 0.1530 & 0.3430 \\
\hline & LOGS & 1473 & 0.215 & 0.1171 & 0.0012 & 0.5249 \\
\hline \multirow[t]{2}{*}{ Tcbn2c } & CORES & 14 & 0.212 & 0.0361 & 0.1740 & 0.2990 \\
\hline & LOGS & 1484 & 0.249 & 0.0826 & 0.0550 & 0.4508 \\
\hline \multirow[t]{2}{*}{ Tcb_green } & CORES & 4 & 0.252 & 0.0252 & 0.2190 & 0.2800 \\
\hline & LOGS & 1139 & 0.186 & 0.0408 & 0.0866 & 0.2829 \\
\hline \multirow[t]{2}{*}{ Tcbmd } & CORES & 109 & 0.127 & 0.0565 & 0.0520 & 0.3180 \\
\hline & LOGS & 3877 & 0.130 & 0.0598 & 0.0016 & 0.3283 \\
\hline \multirow[t]{2}{*}{ Tcbn1v } & CORES & 1 & 0.269 & & 0.2690 & 0.2690 \\
\hline & LOGS & 78 & 0.251 & 0.0488 & 0.1528 & 0.3298 \\
\hline \multirow[t]{2}{*}{ Tcb_lower } & CORES & 32 & 0.211 & 0.0578 & 0.1230 & 0.3200 \\
\hline & LOGS & 2121 & 0.193 & 0.0699 & 0.0327 & 0.3811 \\
\hline \multirow[t]{2}{*}{ Tcbbt } & CORES & 8 & 0.213 & 0.0433 & 0.1630 & 0.2700 \\
\hline & LOGS & 673 & 0.171 & 0.0634 & 0.0716 & 0.3745 \\
\hline \multirow[t]{2}{*}{ Tctn2v } & CORES & 9 & 0.276 & 0.0269 & 0.2400 & 0.3130 \\
\hline & LOGS & 1333 & 0.246 & 0.0880 & 0.0049 & 0.4976 \\
\hline \multirow[t]{2}{*}{ Tctn2c } & CORES & 26 & 0.304 & 0.0819 & 0.1660 & 0.4420 \\
\hline & LOGS & 2037 & 0.180 & 0.0791 & 0.0070 & 0.3932 \\
\hline \multirow[t]{2}{*}{ Tct_blue } & CORES & 5 & 0.134 & 0.0451 & 0.0600 & 0.1800 \\
\hline & LOGS & 4054 & 0.145 & 0.0572 & 0.0014 & 0.2757 \\
\hline \multirow[t]{2}{*}{ Tctn1c } & CORES & 2 & 0.190 & 0.0460 & 0.1570 & 0.2220 \\
\hline & LOGS & 850 & 0.242 & 0.0835 & 0.0546 & 0.3934 \\
\hline \multirow[t]{2}{*}{ Tct_lower } & CORES & 16 & 0.199 & 0.0497 & 0.1090 & 0.2800 \\
\hline & LOGS & 6498 & 0.151 & 0.0716 & 0.0020 & 0.3654 \\
\hline \multirow[t]{2}{*}{ Tctbt } & CORES & 1 & 0.110 & & 0.1100 & 0.1100 \\
\hline & LOGS & 500 & 0.127 & 0.0563 & 0.0081 & 0.2807 \\
\hline \multirow[t]{2}{*}{ Undefined } & CORES & 555 & 0.152 & 0.1308 & 0.0130 & 0.6340 \\
\hline & LOGS & 27950 & 0.168 & 0.0934 & 0.0012 & 0.6325 \\
\hline
\end{tabular}

1) DTNs used in the above tables include DTN MO9910POROCALC.000 (superseded by DTNs MO0010CPORGLOG.002 and MO0010CPORGLOG.003 as a result of this qualification report) and the following core porosity DTNs:

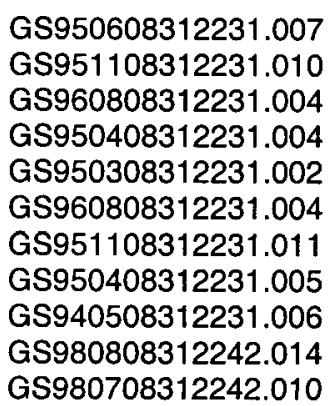




\section{APPENDIX B}

\section{FORENSIC EVALUATION EXCERPTS FOR}

USW H-6 AND UE-25 P\#1 


\section{BOREHOLE H-6}

USW H-6 is located near the west edge of the proposed repository and drilled to a depth of 4002 $\mathrm{ft}$. Geophysical logs were collected on several separate occasions under two different logging contractors, Birdwell and Dresser Atlas. Dresser Atlas logs were found to be qualified by CRWMS M\&O (19960). The dates, depths and geophysical logs run in USW H-6 are shown in Table B-1. No data editing or shifts were found applied to the geophysical logging data on USW H-6.

The logging data considered includes:

- Resistivity

- Bulk Density

- Neutron

- Gamma Ray

- Caliper

- Acoustic.

Olsen and Rael (2001) shows that data types collected in the borehole are mutually corroborating. Figure B1 shows an expected correlation between density, neutron and gamma ray data and Birdwell-acquired induction resistivity data measured in the USW H-6 borehole. Additional comparisons using boreholes USW H-6, USW H-5, and USW SD-6 also support the historical accuracy of the Birdwell resistivity tool data acquisition (Olsen and Rael 2001, Figures $2,3)$.

Both epithermal neutron porosity (ENP) and thermal neutron tools (NBC) were used to collect data in USW H-6. Olsen and Rael (2001) shows a positive correlation between bulk density and neutron data and observed acceptable repeatability between the main passes of the compensated borehole density tool. Olsen and Rael also observed the correlation between the thermal (CNP) and epithermal neutron (ENP) data with respect to density data. They conclude both sets of neutron data and density are responding similarly to the porosity of the rock and are within expected ranges.

Naturally occurring gamma ray emissions of the formations were recorded with every trip into the borehole using either a standard gamma ray tool or a spectral gamma ray tool. Olsen and Rael (2001) found acceptable repeatability among the passes. Likewise, repeatability for the acoustic data was also found to be acceptable and an indication of good quality. Olsen and Rael (2001) also shows a positive correlation between acoustic and compensated neutron data, suggesting both are responding to porosity in a consistent manner. Tolerances were evaluated for caliper data obtained from six arm caliper and density tools in USW H-6 and found to be of adequate quality. 
Table B1. Log Runs in USW H-6 (after Olsen and Rael 2001)

\begin{tabular}{|c|c|c|c|c|c|}
\hline \multirow{2}{*}{$\begin{array}{l}\text { Logging } \\
\text { Company }\end{array}$} & \multirow[b]{2}{*}{ Survey Type } & \multirow[b]{2}{*}{ Runs } & \multirow[b]{2}{*}{ Dates } & \multicolumn{2}{|c|}{ Depth Interval (ft) } \\
\hline & & & & Top & Bottom \\
\hline $\mathrm{D}-\mathrm{A}$ & $\begin{array}{l}\text { BHC Acoustic Fraclog } \\
\text { Gamma Ray }\end{array}$ & 1 & $10 / 01 / 1982$ & 1906 & 3976 \\
\hline$D-A$ & $\begin{array}{l}\text { BHC Acoustilog } \\
\text { Gamma Ray }\end{array}$ & 1 & 10/01/1982 & 1906 & 3976 \\
\hline Birdwell & Caliper Log & 1 & $08 / 13 / 1982$ & 0 & 312 \\
\hline Birdwell & Caliper Log & 2 & $09 / 04 / 1982$ & 25 & 1896 \\
\hline Birdwell & Caliper Log & 3 & $09 / 13 / 1982$ & 0 & 1969 \\
\hline Birdwell & Caliper Log & 4 & 09/30/1982 & 1850 & 3973 \\
\hline Birdwell & Caliper Log & 5 & $12 / 16 / 1982$ & 1850 & 3942 \\
\hline Birdwell & $\begin{array}{l}\text { Density } \\
\text { Borehole Compensated }\end{array}$ & 1 & $09 / 04 / 1982$ & 250 & 1895 \\
\hline Birdwell & \begin{tabular}{|l|} 
Density \\
Borehole Compensated \\
\end{tabular} & 2 & 09/30/1982 & 1870 & 3981 \\
\hline Birdwell & Density Log & 1 & 08/13/1982 & 0 & 310 \\
\hline D-A & Compensated Neutron & 1 & 10/01/1982 & 1730 & 3984 \\
\hline Birdwell & Epithermal Neutron Porosity & 1 & 09/07/1982 & 250 & 1904 \\
\hline Birdwell & Epithermal Neutron Porosity & 2 & $12 / 16 / 1982$ & 250 & 1946 \\
\hline Birdwell & Induction & 1 & 08/13/1982 & 0 & 306 \\
\hline Birdwell & Induction Electric Log & 2 & 09/04/1982 & 300 & 1894 \\
\hline Birdwell & Induction Electric Log & 3 & 09/30/1982 & 1888 & 3976 \\
\hline Birdwell & $\begin{array}{l}\text { Induction Electric Log } \\
\text { (re-run prints) }\end{array}$ & 2 & 09/05/1982 & & \\
\hline Birdwell & Gamma Ray & 1 & $09 / 04 / 1982$ & 250 & 1899 \\
\hline Birdwell & Gamma Ray & 2 & 09/30/1982 & 1874 & 3982 \\
\hline Birdwell & Gamma Ray & 4 & $12 / 16 / 1982$ & 250 & 1938 \\
\hline Birdwell & Gamma Ray & 3 & $12 / 16 / 1982$ & 0 & 3948 \\
\hline
\end{tabular}

Notes for "Borehole" Column

\begin{tabular}{|c|c|}
\hline D-A & Dresser - Atlas \\
\hline
\end{tabular}




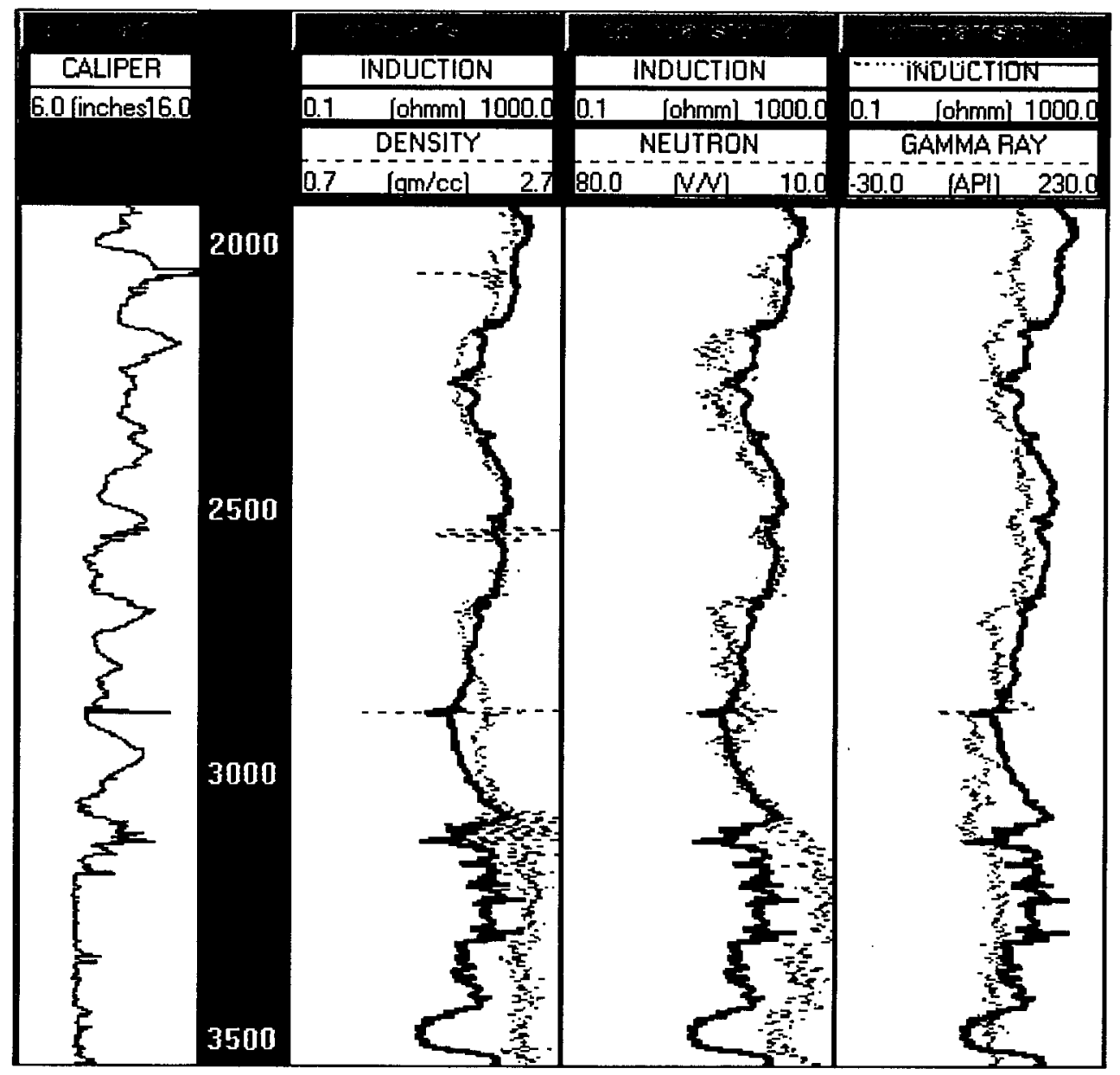

Figure B1. Correlation of Three Induction Runs and Corresponding Density, Neutron and Gamma Ray Curves for USWH-6 (after Olsen and Rael 2001). 
The computed curves for USW H-6 included:

- Thermal Neutron

- Epithermal Neutron.

PHINBC is the thermal neutron porosity curve (NBC) corrected for borehole holesize applied to the porosity transform and used by Rael (1999) in porosity calculations for some historical boreholes. Olsen and Rael (2001) partly reconstructed basic neutron data measured in counts/sec (PHICNP) using data from Nelson (1996) and Atlas (1985). Olsen and Rael's (2001) reconstructed data plotted against Nelsons's final neutron porosity (PHINBC) shows a one-toone correspondence. Consequently, the neutron data used in Rael's (1999) porosity calculations are reproduced and acceptable. The transform is documented in Olsen and Rael (2001). This correlation is reproduced as Figure B2.

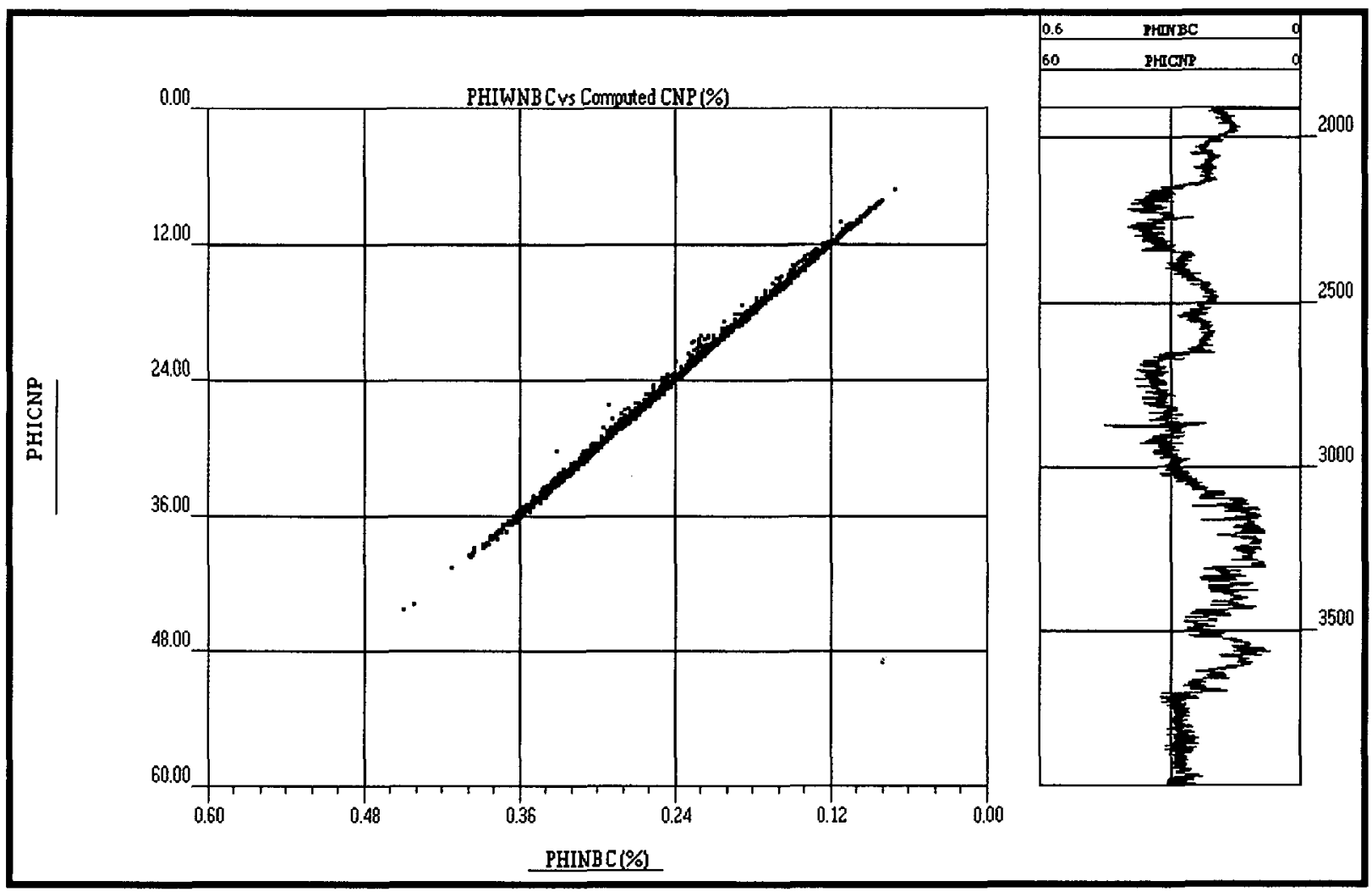

Figure B2. Reconstructed Neutron Data (PHICNP) Plotted Against PHINBC for USW H-6 (Nelson1996) (after Olsen and Rael 2001)

PHIWENP is an epithermal neutron porosity curve derived and documented in Nelson (1996) and used in the porosity calculations by Rael (1999). In his report, Nelson documents the transition of the raw epithermal neutron data (ENP) to the final product, PHIWENP. This is done on a tool by tool basis using parameters determined for each tool configuration and under specified borehole conditions. The Epithermal Neutron Porosity tool used on this well (USW H6) is LABE-6001/23 and is shielded. The equations and pertinent coefficients used in Nelson's report are listed in Olsen and Rael (2001). 
Olsen and Rael (2001) also reconstructed Nelson's (1996) composite epithermal neutron porosity data (PHIWENP) versus the Nelson (1996) raw epithermal data (ENP) with the appropriate air transform applied and demonstrates a one-to-one correspondence. In Figure B3, Olsen and Rael (2001) shows this same cross-plot with the appropriate water transform applied. "IHx $23 \mathrm{~h} 2 \mathrm{o}$ " represents the raw ENP data. This correlation substantiates the algorithms used by Nelson (1996) to produce the neutron data.

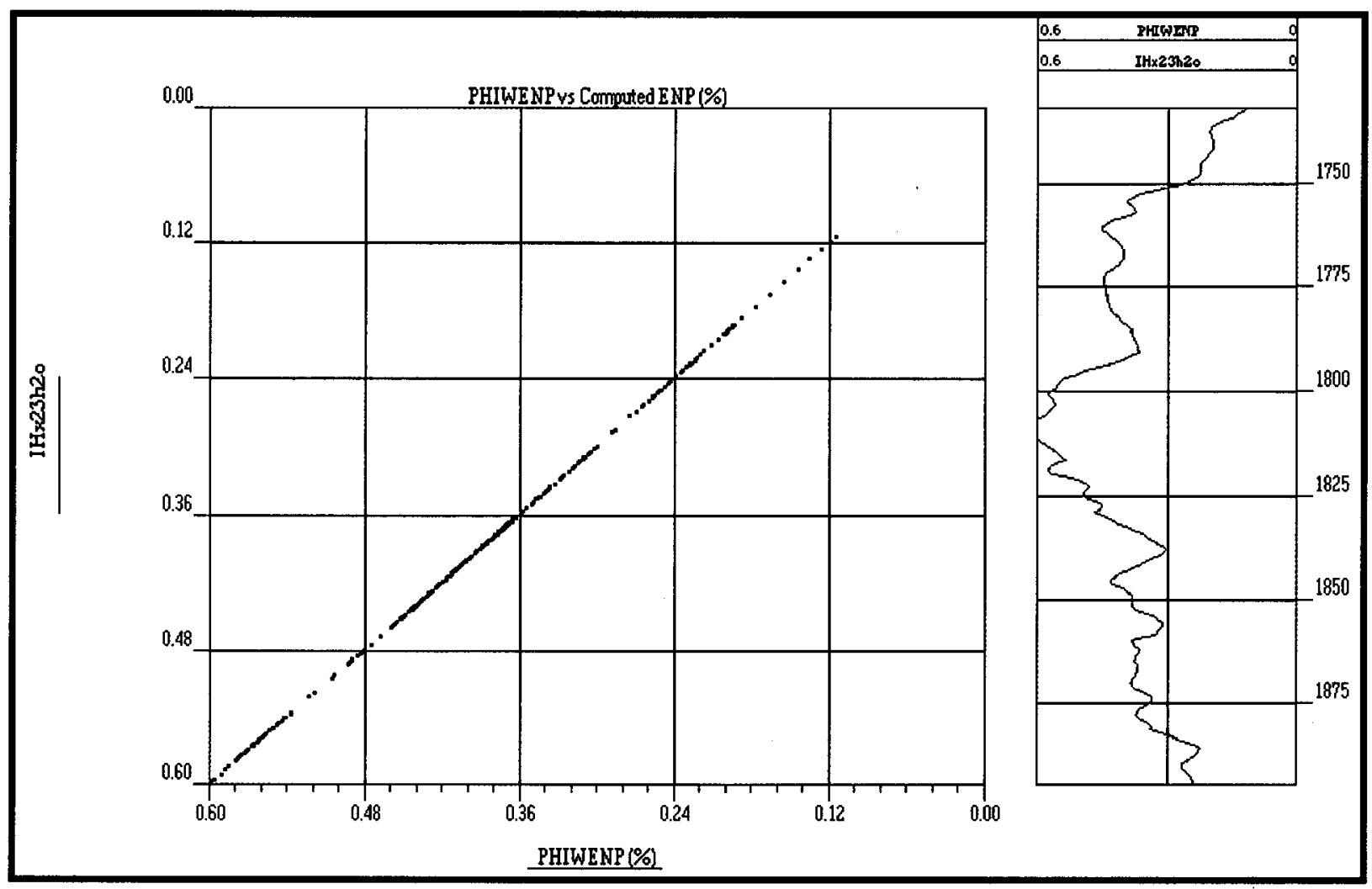

Figure B3. Plot of Nelson (1996) Reconstructed Epithermal Neutron Porosity (PHIWENP) Versus Raw Data with Appropriate Water Transform Applied for USW H-6 (after Olsen and Rael 2001) 


\subsubsection{BOREHOLE UE-25 P\#1}

UE $25 \mathrm{P \# 1}$ was drilled to a depth of $5923 \mathrm{ft}$. and geophysical logs were collected from surface to total depth. Geophysical logs were collected on several separate occasions under two different logging contractors, Birdwell, and Dresser-Atlas (Table B2). Depth shifts and editing were required for selected gamma ray and acoustic recordings, as described in Rael (2001).

The logging data considered includes:

- Resistivity

- Bulk Density

- Neutron

- Gamma Ray

- Caliper

- Acoustic

- Dieletric Log

As with USW H-6, Rael (2001) shows several mutually corroborating comparisons among the data types collected in the UE-25 p\#1, including qualified and unqualified logs. Conventional induction resistivity data, representing deep resistivity (RILD) and short normal resistivity (SN) were collected by Birdwell using induction log (IES) and electric log (EL) tools in UE-25 p\#1. Based on comparing results of multiple passes, Rael (2001) demonstrated repeatability and similarity of the data between the two tools. This observation supports the accuracy of the Birdwell resistivity measurements. Dresser Atlas also logged UE-25 p\#1 with dual induction focused logs. Rael (2001) shows the expected correlation between the dual induction resistivity data to several other types of related data, including bulk density, thermal neutron data logged in counts per seconds as compensated neutron porosity (CNT), gamma ray and caliper data. These correlations suggest accurate acquisition of the historical logging data.

Birdwell used the borehole compensated density tool to acquire bulk density data (DBC). Dresser-Atlas also used this tool in one measurement. The compensated density tool also provided the bulk density correction and caliper data. Neutron porosity (CNT), acoustic data (BHC) and density data (RHOB) shown on the same plot demonstrate agreement among these sets of data, all of which are responding to the porosity of the rock (Rael 2001). Both epithermal neutron porosity (ENP) and thermal neutron tools (NBC) were used to collect data in UE-25 p\#1. Data collected from both tools show the same positive correlation with respect to the bulk density data, neutron, and acoustic curves (Rael 2001). These correlations suggest accurate acquisition of this logging data.

As with USW H-6, gamma ray emissions of the formations were recorded with every trip into the UE-25 p\#1 borehole using either the standard gamma ray tool or the spectral gamma ray tool. Rael (2001) found acceptable repeatability among the different passes into the borehole.

Tolerances were also evaluated for UE-25 p\#1 caliper data obtained from six arm caliper and density tools and found to be of adequate quality (Rael 2001). The data is also corroborated with other measurements (e.g. neutron and density curves). Rael (2001) also demonstrated the acceptable repeatability of acoustic data, an indication of good quality. 
Table B2. Logging Tools Run in UE-25 p\#1 (after Rael 2001)

\begin{tabular}{|c|c|c|c|c|c|}
\hline \begin{tabular}{|l|} 
Logging \\
Company
\end{tabular} & Survey Type & Runs & Dates & Top (ft) & Bottom (ft) \\
\hline$(D-A)$ & BHC AcoustilogGamma Ray & 1 & $01 / 18 / 1983$ & 1582 & 3922 \\
\hline$(\mathrm{D}-\mathrm{A})$ & BHC Acoustilog Gamma Ray & 2 & $03 / 09 / 1983$ & 4000 & 4260 \\
\hline$(D-A)$ & BHC Acoustilog Gamma Ray & 1 & $05 / 03 / 1983$ & 4257 & 5910 \\
\hline$(D-A)$ & BHC Acoustilog Gamma Ray & 2 & $06 / 02 / 1983$ & 4256 & 5902 \\
\hline (Birdwell) & Caliper Log & 1 & $11 / 16 / 1982$ & 6 & 309 \\
\hline (Birdwell) & Caliper Log & 2 & $11 / 18 / 1982$ & 5 & 319 \\
\hline (Birdwell) & Caliper Log & 3 & $11 / 30 / 1982$ & 272 & 1578 \\
\hline (Birdwell) & Caliper Log & 4 & $12 / 03 / 1982$ & 275 & 1569 \\
\hline (Birdwell) & Caliper Log & 1 & $01 / 16 / 1983$ & 1498 & 3930 \\
\hline (Birdwell) & Caliper Log & 6 & $01 / 22 / 1983$ & 3850 & 3966 \\
\hline (Birdwell) & Caliper Log & 7 & $01 / 22 / 1983$ & 3688 & 3953 \\
\hline (Birdwell) & Caliper Log & 8 & $01 / 24 / 1983$ & 1200 & 1584 \\
\hline (Birdwell) & Caliper Log & 9 & $01 / 24 / 1983$ & 1206 & 3921 \\
\hline (Birdwell) & Caliper Log & 10 & $02 / 22 / 1983$ & 1498 & 3915 \\
\hline$(D-A)$ & Caliper Log & 1 & $03 / 05 / 1983$ & 1562 & 3932 \\
\hline (Birdwell) & Caliper Log & 11 & $03 / 07 / 1983$ & 3876 & 4050 \\
\hline (Birdwell) & Caliper Log & 12 & $03 / 08 / 1983$ & 3927 & 4246 \\
\hline (Birdwell) & Caliper Log & 13 & $03 / 30 / 1983$ & 4190 & 4310 \\
\hline (Birdwell) & Caliper Log & 14 & $05 / 02 / 1983$ & 4180 & 5912 \\
\hline (Birdwell) & Caliper Log & 15 & $01 / 05 / 1984$ & 4200 & 5903 \\
\hline$(D-A)$ & Compensated Neutron & 1 & $01 / 18 / 1983$ & 1582 & 3920 \\
\hline$(\mathrm{D}-\mathrm{A})$ & Compensated Neutron & 2 & $03 / 08 / 1983$ & 2900 & 4212 \\
\hline$(D-A)$ & Compensated Neutron & 3 & $03 / 09 / 1983$ & 4000 & 4260 \\
\hline$(D-A)$ & Compensated Neutron & 1 & $05 / 03 / 1983$ & 4000 & 5918 \\
\hline (Birdwell) & Epithermal Neutron Porosity & 1 & $12 / 01 / 1982$ & 300 & 1583 \\
\hline (Birdwell) & Epithermal Neutron Porosity & 2 & $01 / 17 / 1983$ & 1540 & 3924 \\
\hline (Birdwell) & Epithermal Neutron Porosity & 3 & $05 / 03 / 1983$ & 4182 & 5918 \\
\hline (Birdwell) & Density-Borehole Compensated & 1 & $11 / 16 / 1982$ & 20 & 315 \\
\hline (Birdwell) & Density-Borehole Compensated & 2 & $11 / 30 / 1982$ & 290 & 1581 \\
\hline (Birdwell) & Density-Borehole Compensated & 3 & $03 / 08 / 1983$ & 2879 & 4213 \\
\hline (Birdwell) & Density-Borehole Compensated & 4 & $03 / 09 / 1983$ & 3950 & 4253 \\
\hline (Birdwell) & Density-Borehole Compensated & 5 & $05 / 03 / 1983$ & 4190 & 5917 \\
\hline$(\mathrm{D}-\mathrm{A})$ & Densilog-Gamma Ray & 1 & $01 / 18 / 1983$ & 1582 & 3930 \\
\hline$(D-A)$ & Dielectric Log & 1 & $05 / 04 / 1983$ & 4256 & 5914 \\
\hline$(\mathrm{D}-\mathrm{A})$ & Dual Induction Focused Log & 1 & $01 / 18 / 1983$ & 1582 & 3930 \\
\hline$(D-A)$ & Dual Induction Focused Log & 2 & $03 / 09 / 1983$ & 4000 & 4262 \\
\hline$(D-A)$ & Dual Induction Focused Log & 1 & $05 / 03 / 1983$ & 4257 & 5917 \\
\hline (Birdwell) & Induction & 1 & $11 / 17 / 1982$ & 29 & 311 \\
\hline (Birdwell) & Induction Electric Log & 2 & $11 / 30 / 1982$ & 326 & 1577 \\
\hline (Birdwell) & Electric Log & 1 & $06 / 23 / 1983$ & 4226 & 5908 \\
\hline (Birdwell) & Gamma Ray & 1 & $12 / 01 / 1982$ & 300 & 1580 \\
\hline (Birdwell) & Gamma Ray & 2 & $01 / 17 / 1983$ & 1550 & 3927 \\
\hline$(D-A)$ & Spectralog Gamma Ray & 1 & $01 / 18 / 1983$ & 0 & 3930 \\
\hline$(D-A)$ & Spectralog Gamma Ray & 2 & $03 / 08 / 1983$ & 2900 & 4212 \\
\hline$(D-A)$ & Spectralog Gamma Ray & 1 & $05 / 04 / 1983$ & 2500 & 5917 \\
\hline
\end{tabular}


Dresser-Atlas ran a dielectric log in UE-25 $\mathrm{p \# 1}$ that responds to properties in the surrounding rock, such as density, neutron, and resistivity. Rael (2001) showed consistency among these properties as well as repeatability among measurements.

The computed curves (UE-25 p\#1) considered include:

- Thermal Neutron

- Epithermal Neutron

PHINBC is the thermal neutron porosity curve (NBC) corrected for borehole holesize applied to the porosity transform and used by Rael (1999) in porosity calculations for some historical boreholes. Rael (2001) partly reconstructed basic neutron data (PHICNP) using data from Nelson (1996) and Atlas (1985). The reconstructed data plotted against Nelsons's (1996) final neutron porosity (PHINBC) shows essentially a one-to-one correspondence. Consequently, the neutron data used in Rael's (1999) porosity calculations are reproducible and acceptable. The transform is documented in Rael (2001). This correlation is reproduced as Figure B4.

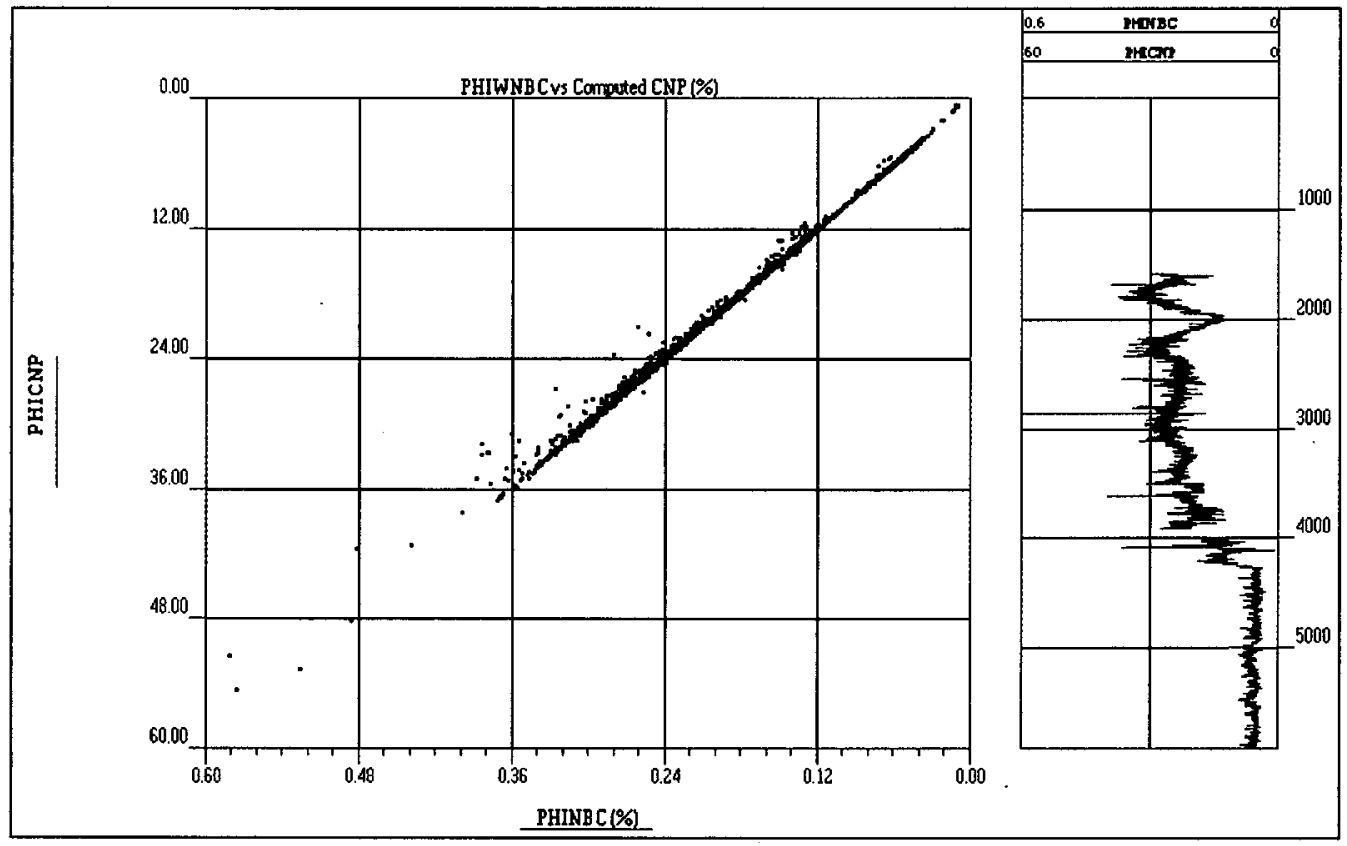

Figure B4. Comparison of PHINBC (Nelson 1996) and PHICNP for UE-25 p\#1 (after Rael 2001)

PHIWENP is the epithermal neutron porosity curve derived and documented in Nelson (1996) and used in the porosity calculations by Rael (1999). The epithermal neutron porosity tool used on this well (UE $25 \mathrm{P \# 1)} \mathrm{is} \mathrm{LABE-6001/23} \mathrm{and} \mathrm{was} \mathrm{run} \mathrm{shielded} \mathrm{and} \mathrm{unshielded.} \mathrm{Rael} \mathrm{(2001)}$ plotted Nelson's final epithermal neutron porosity data (PHIWENP) against the raw data (computed ENP) with the appropriate air transform applied. The linear relationship and reproducibility of the data support adequacy of the neutron data used in the porosity calculations (Figure B5). The pertinent equations are included in Rael (2001). 


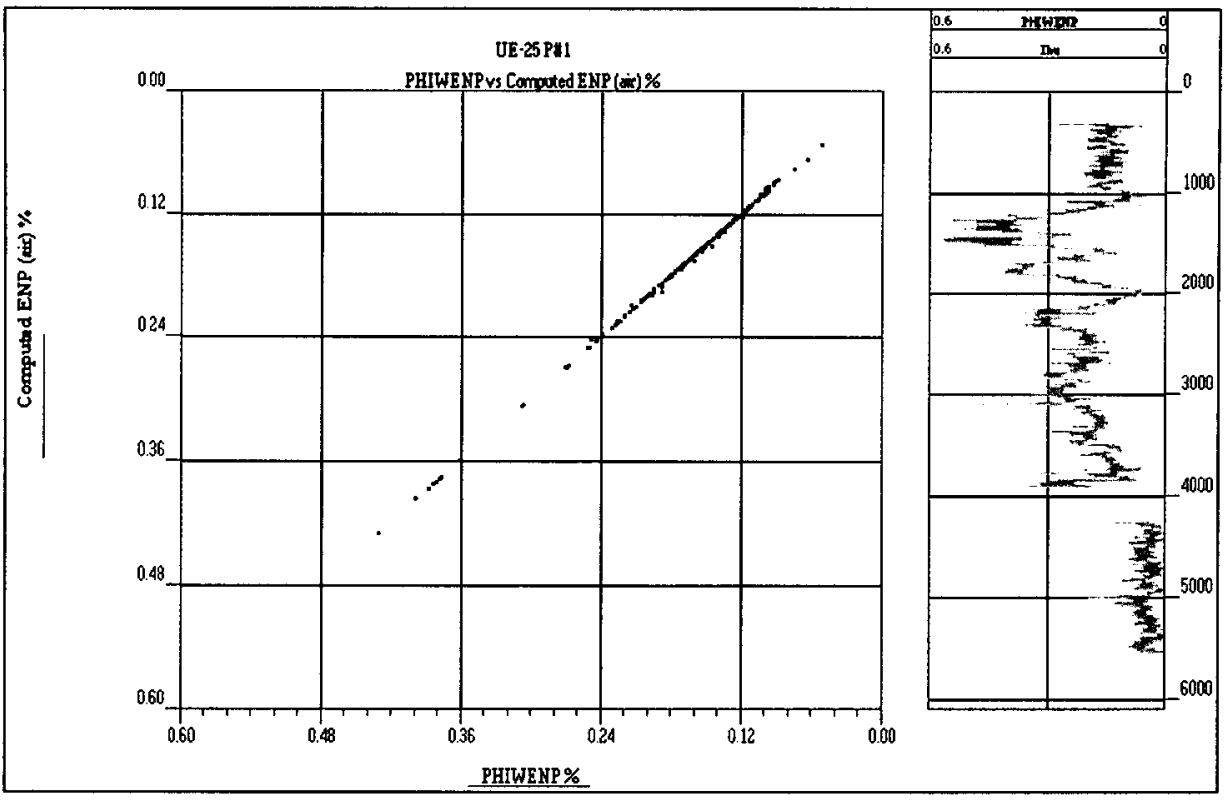

Figure B5. Plot of Reconstructed Epithermal Neutron Porosity Versus Raw (computed ENP) Porosity Data in Air (shielded) from Nelson (1996) for UE-25 p\#1 (after Rael 2001)

Nelson's final epithermal neutron porosity data (PHIWENP) was plotted vs. a reconstruction from the raw data (computed PHIWENP), with the shielded water transform applied. These composite data are shown to correspond adequately to each other over all ranges (Figure B6). 


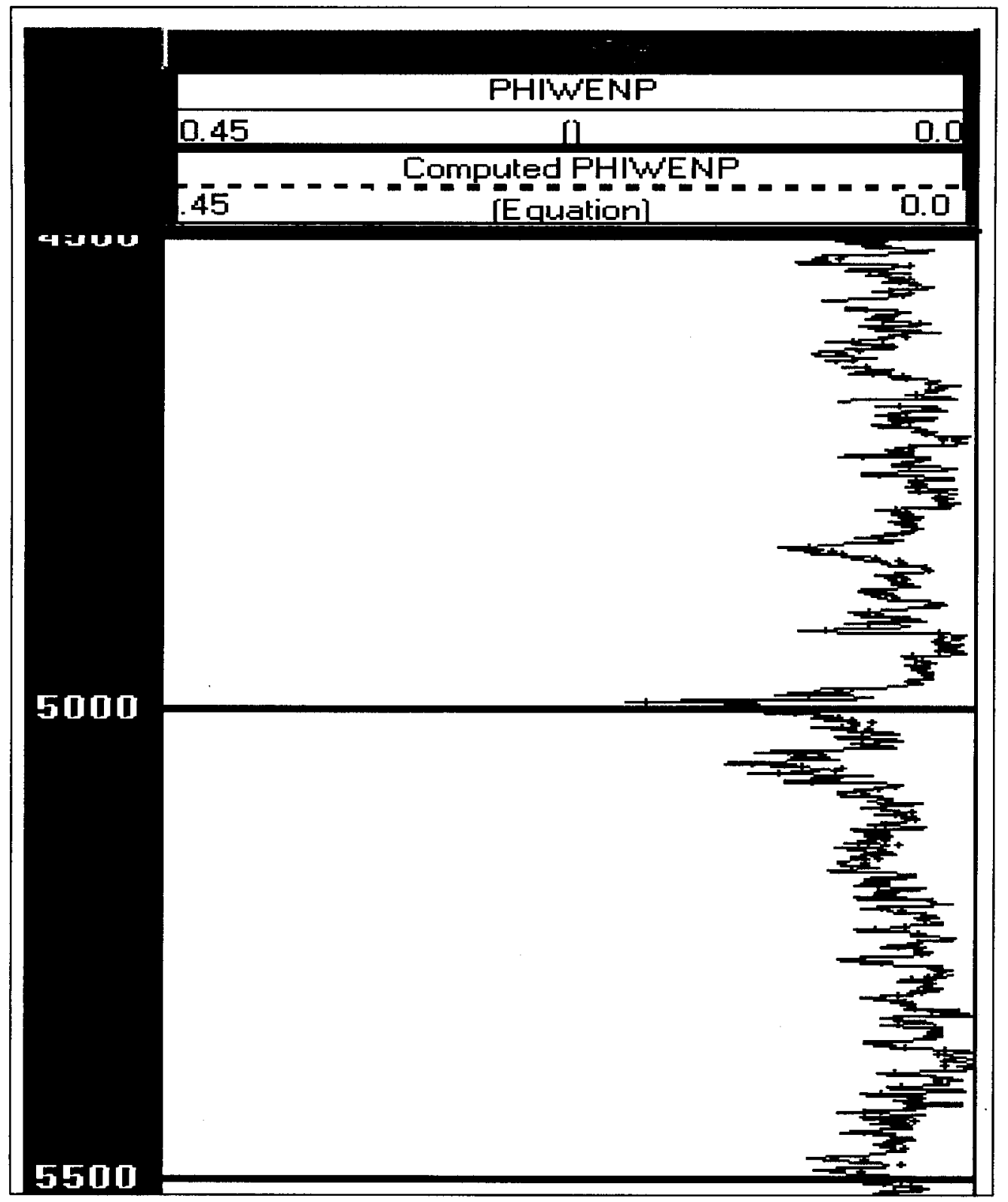

Figure B6. Plot of Nelson (1996) Reconstructed Epithermal Neutron Porosity (PHIWENP) Versus Raw Data (computed PHIWENP) in Water (unshielded) from Nelson (1996) for UE-25 p\#1 (after Rael 2001) 


\section{APPENDIX C}

\section{COMPARISON OF OLD AND MODERN INPUTS AND OUTPUTS FOR HISTORIC WELLS}




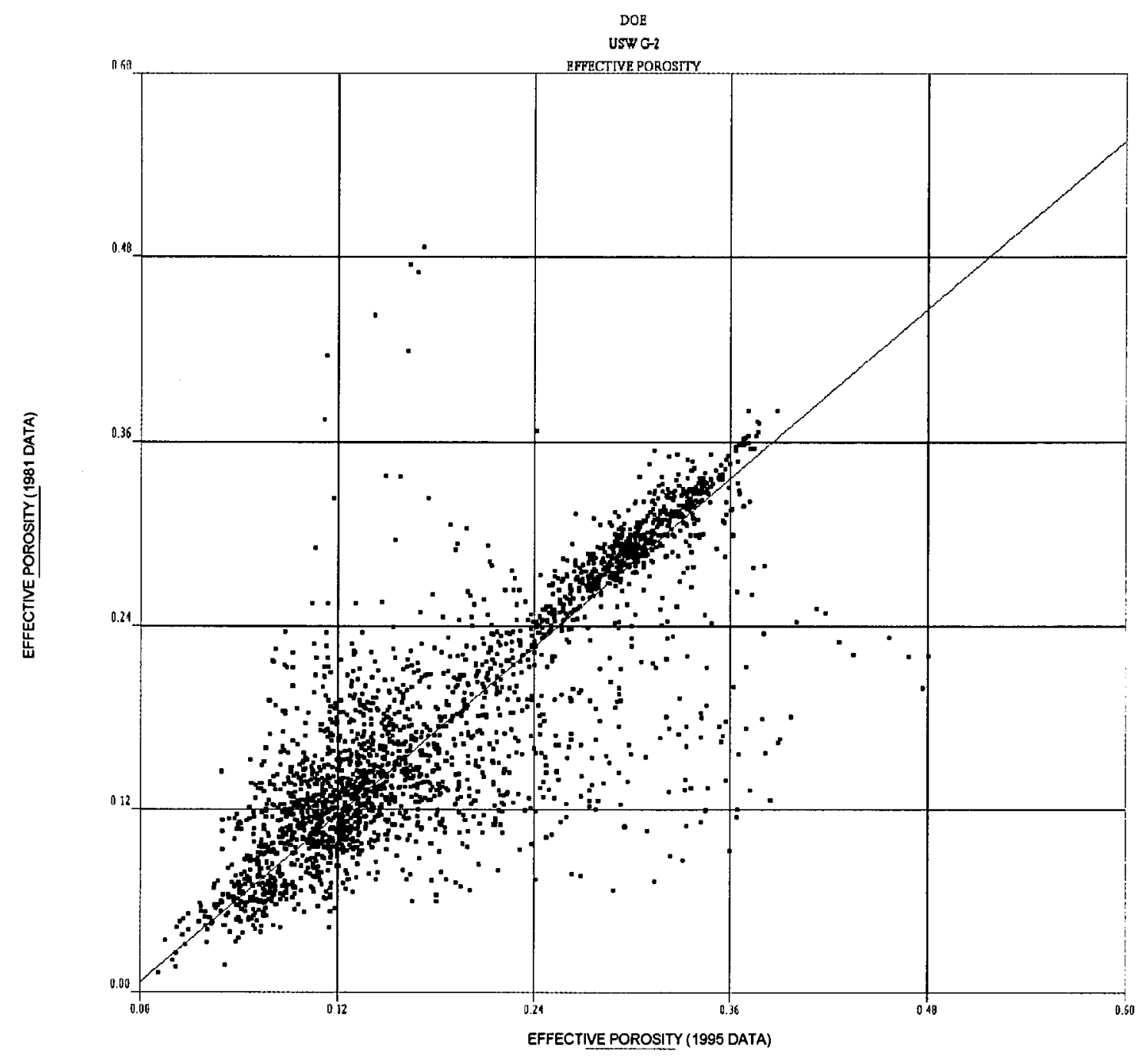

Figure C1. Comparison Between the USW G-2 Effective Porosities Computed from the Old and Modern Data Sets.

Figure $\mathrm{C} 1$ demonstrates a linear trend between the effective porosity results calculated with modern and old data sets, especially at higher porosities. The trend is linear at lower porosities until about $0.12 \mathrm{pu}$ where the trend displays a less linear trend until about $.24 \mathrm{pu}$. The error is approximately 0.04 porosity units (pu) at $0.60 \mathrm{pu}$. 


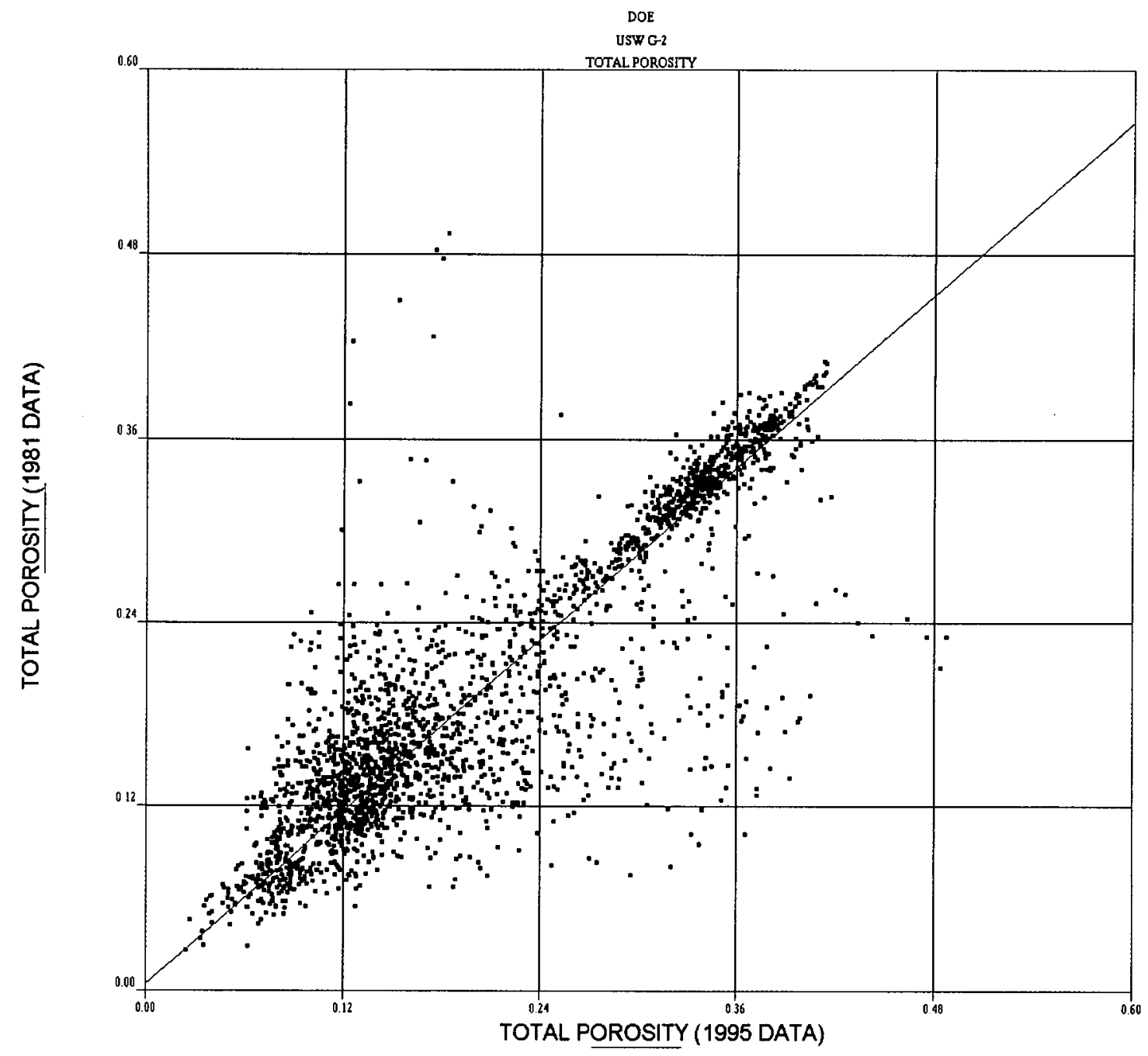

Figure C2. Comparison Between the USW G-2 Total Porosities Computed from the Old and Modern Data Sets.

The comparison displays the same character as linear trend for USW G-2 effective porosity. The error is approximately 0.03 porosity units $(\mathrm{pu})$ at $0.60 \mathrm{pu}$. 


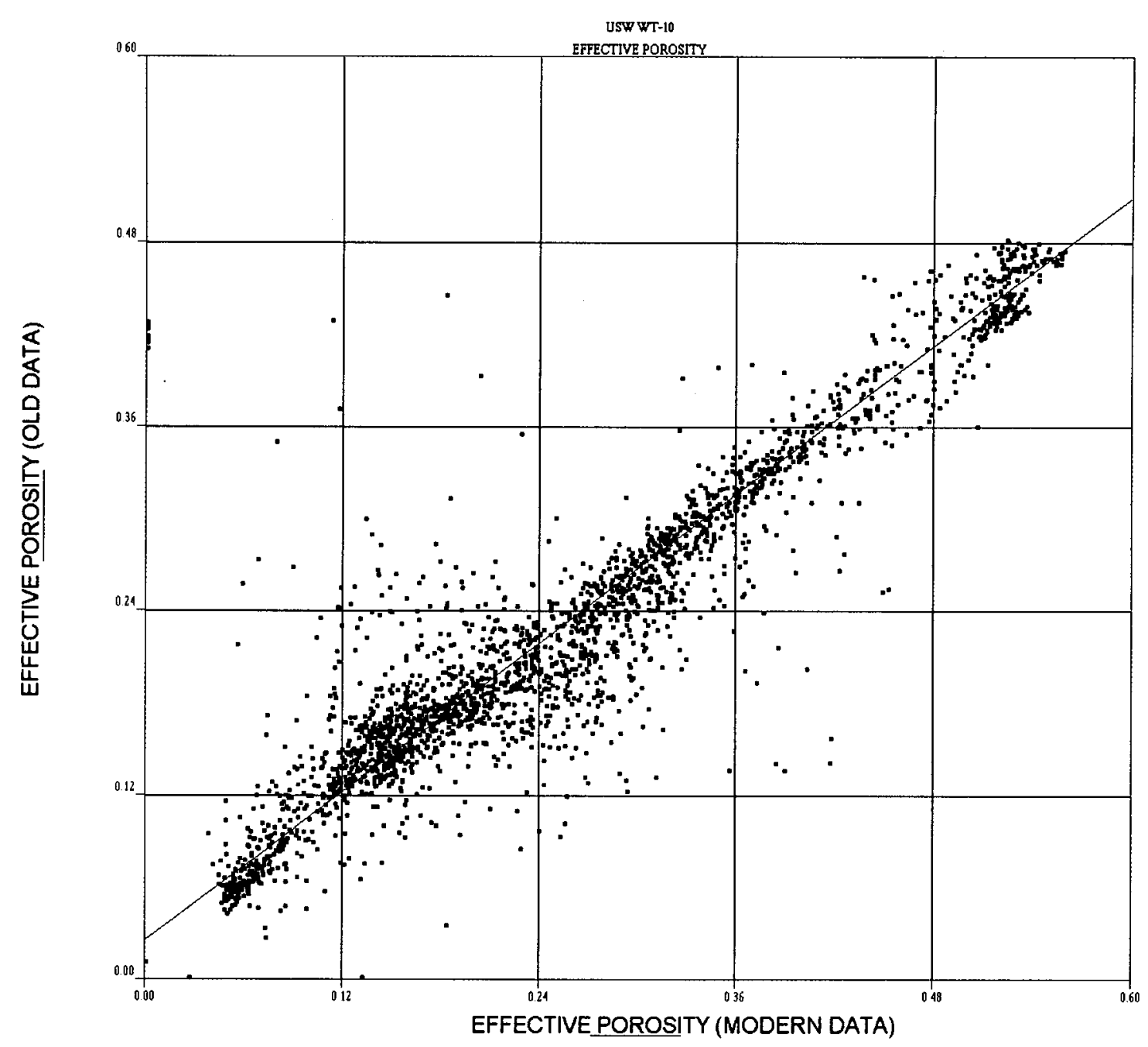

Figure C3. Comparison Between the USWWT-10 Effective Porosities Computed from the Old and Modern Data Sets.

Figure C3 demonstrates a better linear trend for the effective porosity comparison than USW G2 . This is despite differences in the density and neutron data sets. The maximum error is about $0.09 \mathrm{pu}$. 


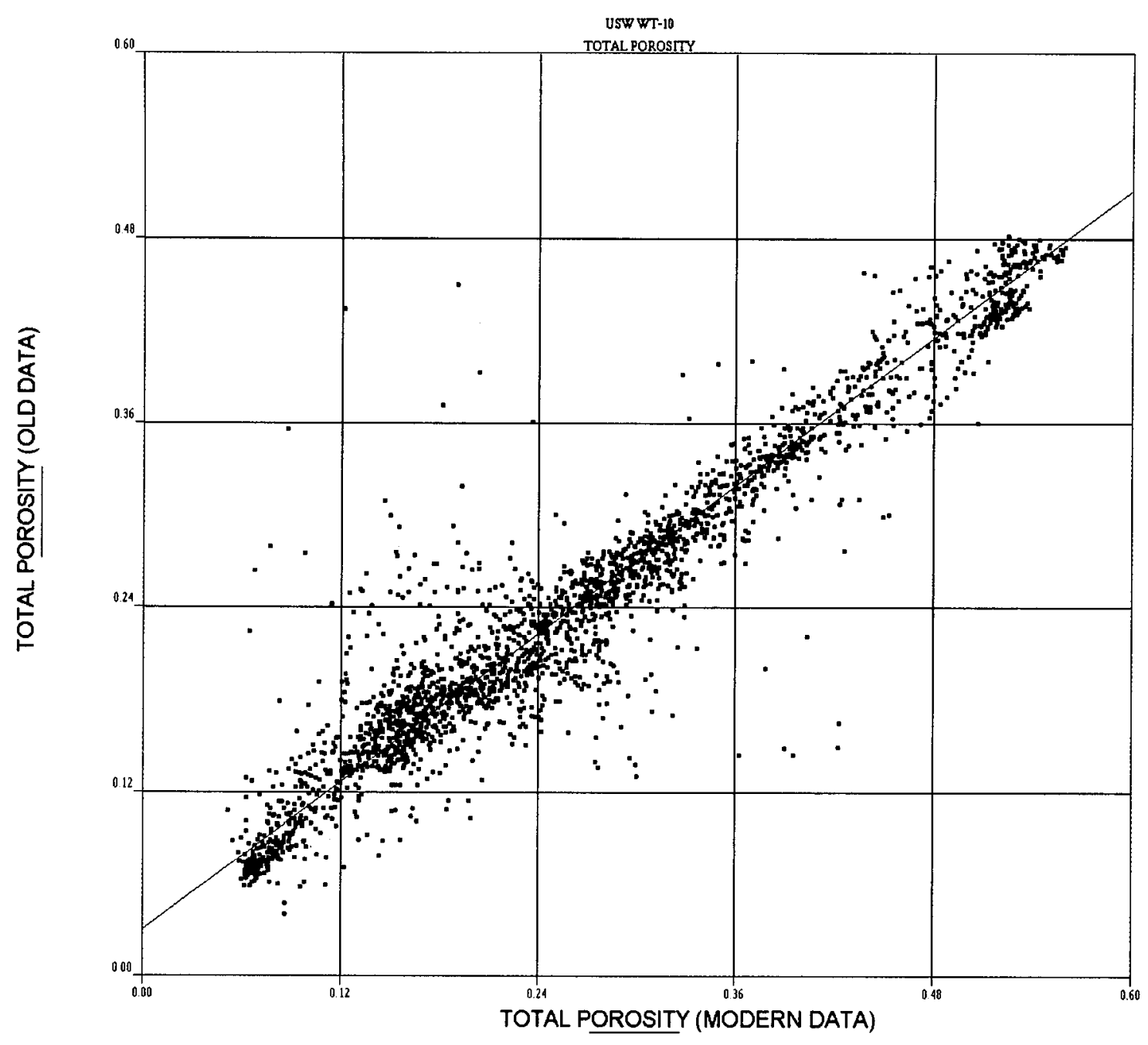

Figure C4. Comparison Between the USWWT-10 Total Porosity Values Computed from the Old and Modern Data Sets.

The USW WT-10 total porosity comparison shows a similarly good linear trend as effective porosity. The maximum error is also about $0.09 \mathrm{pu}$ at $0.60 \mathrm{pu}$. 


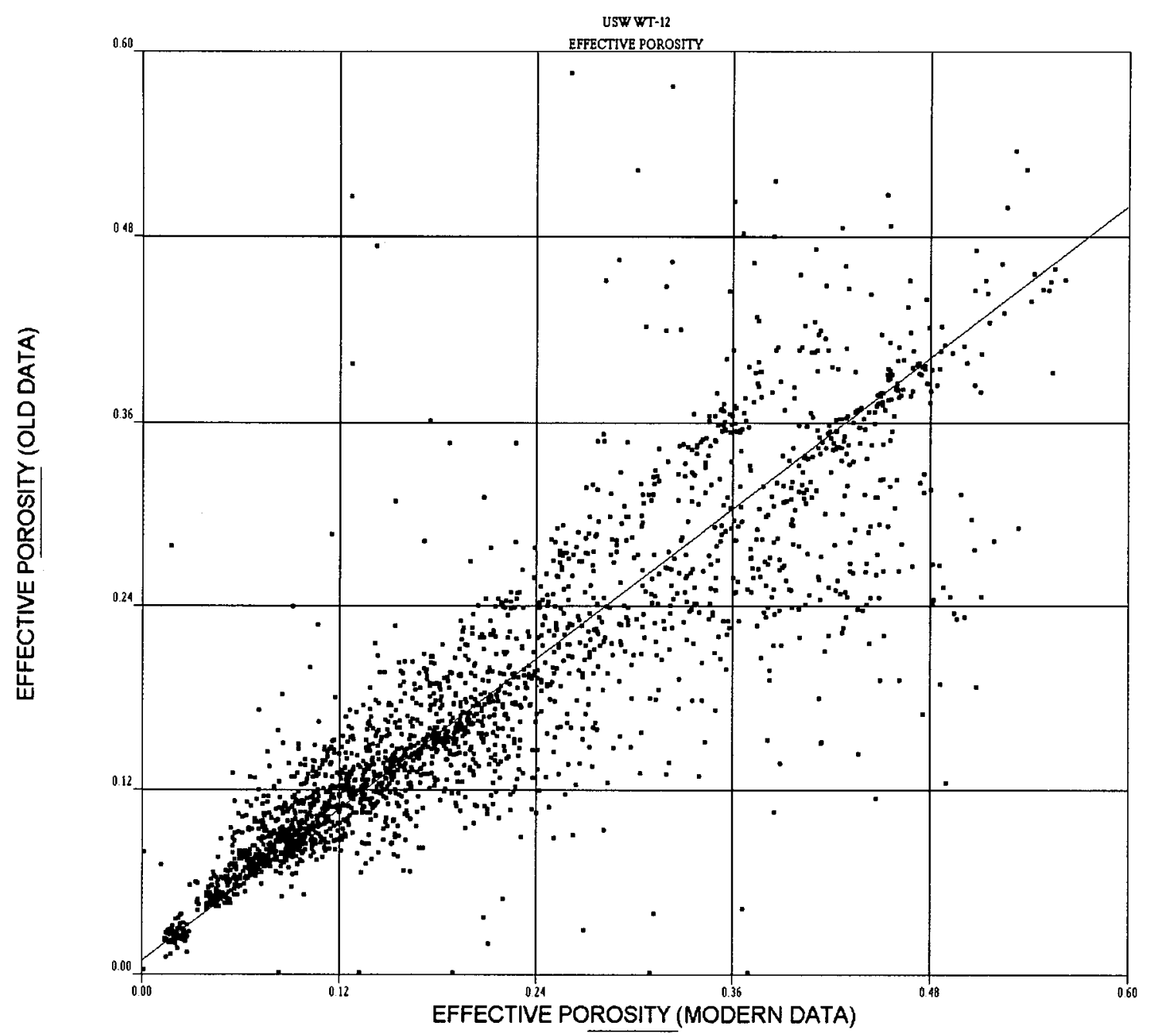

Figure C5. Comparison Between UE-25 WT-12 Effective Porosity Values Computed from the Old and Modern Data Sets.

Figure $\mathrm{C} 5$ shows the UE-25 WT-12 linear trend below 0.15 pu but becomes more incoherent as the porosity increases. In this case, at higher porosities the scatter suggests that hole conditions are affecting the comparison. 


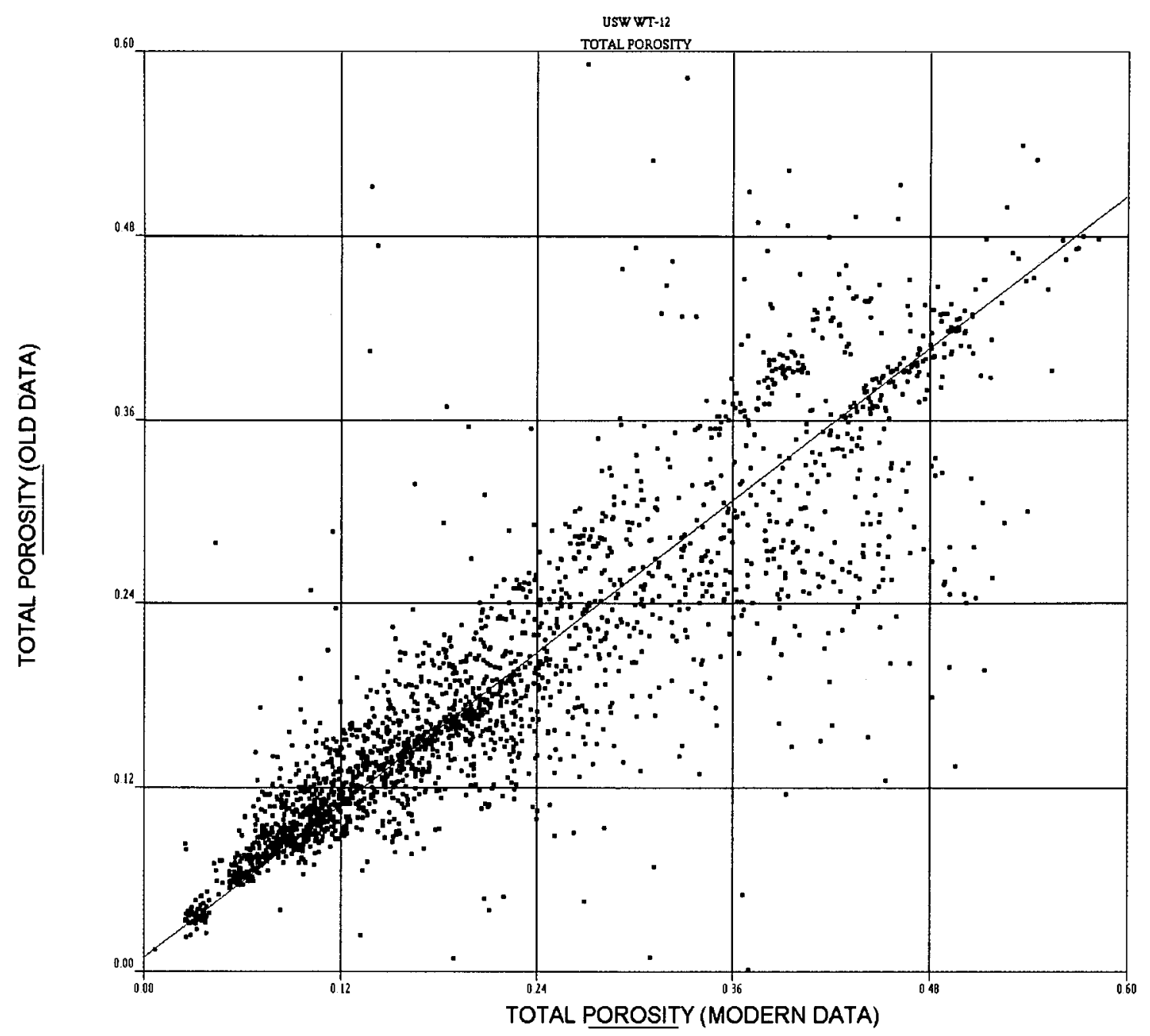

Figure C6. Comparison Between UE-25 WT-12 Total Porosity Values Computed Using Old and Modern Data Sets.

The total porosity comparison for UE-25 WT- 12 is also affected by hole conditions above 0.15 pu, similar to the effective porosity. 


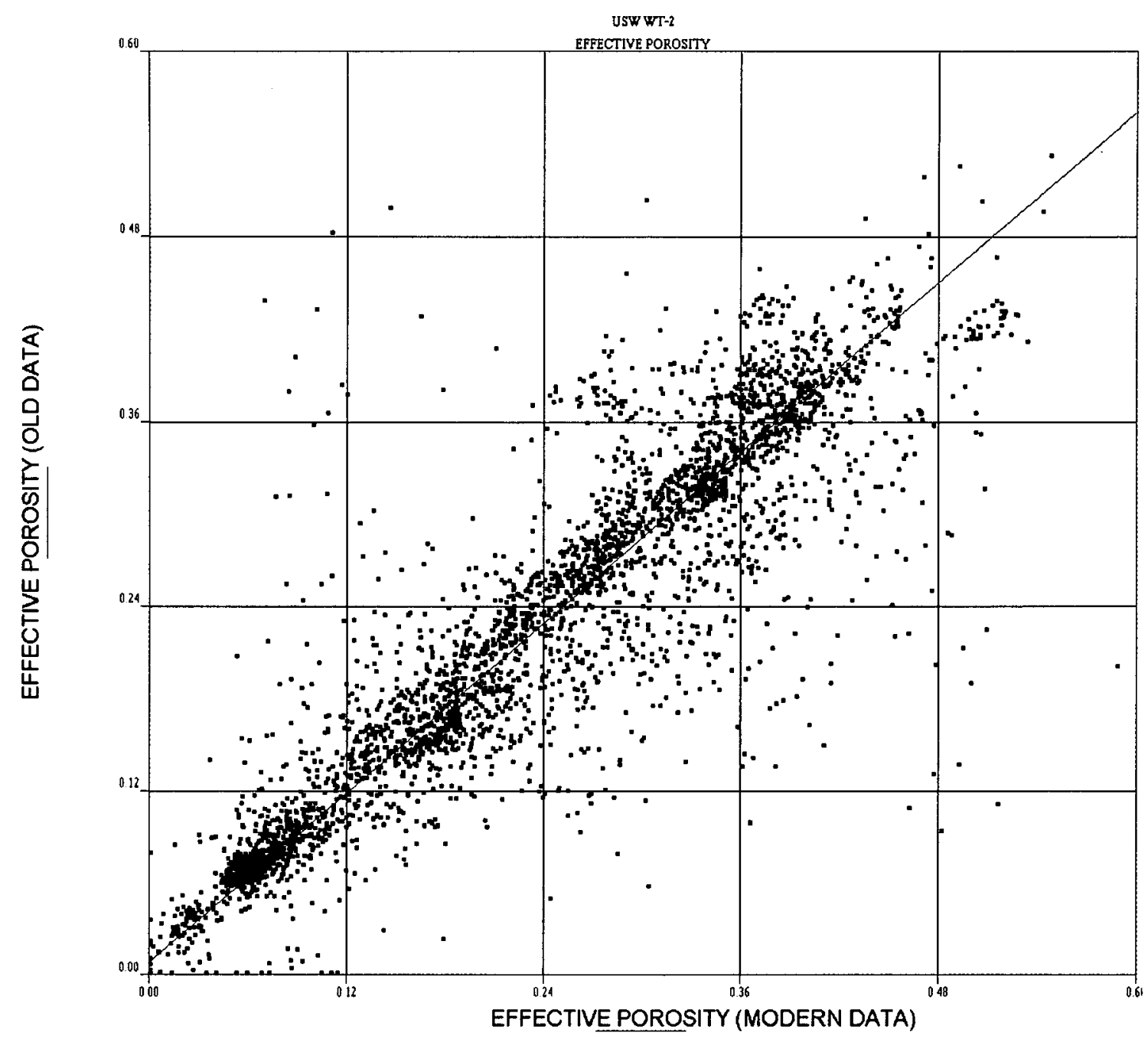

Figure C7. Comparison Between USWWT-2 Effective Porosity Values Computed from the Old and Modern Data Sets.

The comparison between the effective porosity data are quite good considering the differences between the density and neutron data. The maximum error at $0.60 \mathrm{pu}$ is $0.04 \mathrm{pu}$. 


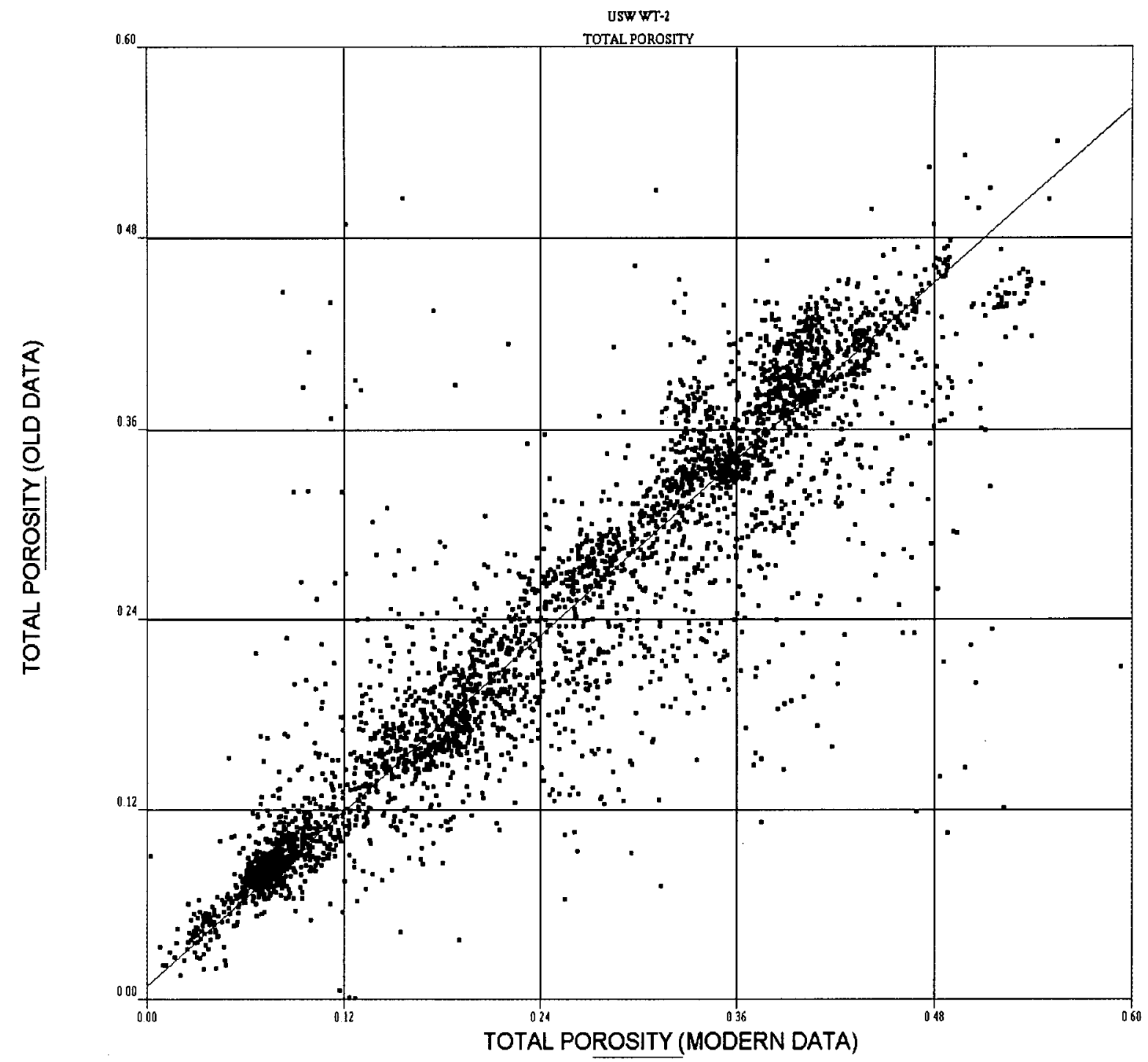

Figure C8. Comparison Between USWWT-2 Total Porosity Values Computed from the Old and Modern Data Sets.

Similar to the effective porosity for USW WT-2, the difference between the total porosity calculations using historical and modern borehole datasets is about $0.04 \mathrm{pu}$ at $0.60 \mathrm{pu}$. 